\title{
RMIRep: Suporte para Replicação de Objetos em Redes de Alta Latência
}

Jorge Chaves Radel Bittencourt

\author{
DISSERTAÇÃO APRESENTADA AO \\ INSTITUTO DE MATEMÁTICA E ESTATÍSTICA DA \\ UNIVERSIDADE DE SÃO PAULO PARA \\ OBTENÇÃO DO GRAU DE MESTRE EM \\ CIÊNCIA DA COMPUTAÇÃO
}

Área de Concentração: Ciência da Computação Orientadora: Profa. Dra. Dilma Menezes da Silva

— São Paulo, maio de 2001 -

$\mathrm{Na}$ elaboração desse trabalho, o autor obteve apoio financeiro do CNPq. 


\title{
RMIRep: Suporte para Replicação de Objetos em Redes de Alta Latência
}

\author{
Este exemplar corresponde à redação \\ final da dissertação devidamente corrigida \\ e defendida por Jorge Chaves Radel Bittencourt \\ e aprovada pela comissão julgadora.
}

São Paulo, 22 de junho de 2001

Banca examinadora:

- Profa. Dra. Dilma Menezes da Silva (orientadora, IBM Watson Research Center)

- Profa. Dra. Taisy Silva Weber (Instituto de Informática-UFRGS)

- Prof. Dr. Fábio Kon (IME-USP) 
Aos cristãos da USP, por terem tanta coragem e por serem uma inspiração para mim. Esses versículos me lembram de vocês:

Como, pois, invocarão aquele em quem não creram? E como crerão naquele de quem não ouviram falar? E como ouvirão, se não houver quem pregue? $E$ como pregarão, se não forem enviados? Como está escrito: "Como são belos os pés dos que anunciam boas novas!"

Romanos 10:14-15 


\section{Agradecimentos}

A Deus, por ser meu melhor amigo e por me amar de uma maneira tão radical.

À USP, ao IME e ao CNPq, por terem me dado a oportunidade e as condições de cursar o meu mestrado. À Professora Dilma, por ser tão excelente. Obrigado por suas direções! Ao meu amigo Téo, por ter aguentado minha chatice no começo do curso. Aos frequentadores do LCPD, obrigado por terem me aguentado vivendo lá nos últimos tempos. Ao Francisco, em especial, por ser tão prestativo.

À minha família, por ter construído o meu caráter e ter me dado a base para que eu pudesse tomar as decisões certas na minha vida. Vocês sempre demonstraram muito amor e carinho e, mesmo longe, são uma parte insubstituível da minha vida. À minha mãe, em especial, por ser a mulher que eu mais admiro no mundo: você é corajosa e possui uma força interior que eu respeito muito. Ao Vel, por ser um homem íntegro e sensível. Eu sonho muito com os planos de Deus para sua vida. À minha irmã, por ter tanto coração para as coisas e por gostar tanto de mim ;-). Aos meus avós, por serem tão corujas!

Os últimos três meses do meu mestrado foram um verdadeiro teste à minha sanidade e eu devo muita gratidão à Igreja de Cristo Internacional de São Paulo por ter me dado ânimo e esperança durante esse tempo. Ao Othon e a Gabi, por serem pais para mim aqui em São Paulo. Othon, sua paciência e visão por minha vida me tocam pra caramba, obrigado por ter me ensinado a sempre terminar o que eu começo. À Ana, por ser minha melhor amiga e uma namorada vinda do céu. Sua vida me inspira respeito e o seu zelo e temor a Deus me fazem admirá-la muito! Ao Gera, por ter cuidado tanto de mim: você, no auge dos seus 20 anos, tem um coração que eu quero muito imitar!

Obrigado pelas visitas de muitos ao meu lab: Diniz, você bateu o relógio mais do que ninguém, obrigado pelas caronas e por ouvir as minhas reclamações! Fredão, sua humildade e sensibilidade me encorajaram muito. Márcio, obrigado pelas encomendas. Cari, valeu por transportar meu colchão várias vezes (e a mim também!). Jama, Martins e Rony, obrigado por me perdoarem. Rony, você é um irmão muito especial! Fausto, o nosso tempo na raia me ajudou muito! Flávio, obrigado por me chamar para participar daqueles estudos e por sua sinceridade. Big Emmer, eu admiro muito o seu companheirismo e simplicidade. Jef Jones, é difícil não querer ser um pai pra você. Almir, Caputo, Fausto e Cláudio, embora longes, eu amo muito vocês!

Aos terráqueos de $\mathrm{Oz}$ (Massa, Chila e Márcio), obrigado pela amizade, pelas faxinas e por terem entendido minha ausência em tantos cafés da manhã (eu sei que o Chila no fundo gostou, sobrou mais pão para ele :-).

Finalmente, obrigado Diniz, Ana, Shig, Chila e Mateus por terem aprendido tudo sobre replicação de dados para poderem me ajudar na correção do texto da dissertação. 


\section{Resumo}

O avanço na tecnologia de computadores móveis, como laptops e PDAs, tem permitido amplo acesso a diversos sistemas de informação distribuídos. $\mathrm{O}$ uso de computadores móveis introduz novos desafios ao projeto e à implementação de aplicações em redes de alta latência, que devem lidar com conectividade intermitente, desconexões freqüentes e taxas de transmissão de dados baixas. Em particular, computadores móveis precisam ter acesso à informação mesmo quando desconectados.

A replicação de dados é uma solução atraente para disponibilizar acesso a sistemas de informação distribuídos em redes de alta latência. Nessa dissertação investigamos a política de consistência fraca Bayou, desenvolvida no Xerox PARC. Políticas de replicação com consistência fraca permitem que servidores distintos leiam e modifiquem dados sem haver coordenação contínua e explícita entre eles, aumentando a disponibilidade da informação. Bayou é inovador pois permite que aplicações controlem o equilíbrio entre os graus de disponibilidade, inconsistência e reconciliação dos dados, através das políticas de usuário, que podem ser configuradas para satisfazerem as necessidades específicas da aplicação.

Apresentamos o projeto e a implementação do sistema RMIRep, que fornece suporte para o desenvolvimento e a análise de mecanismos de consistência. Integramos três desses mecanismos ao RMIRep: a política de réplicas independentes, a política de dados totalmente sincronizados e uma adaptação da política Bayou. Realizamos experimentos com as políticas total e Bayou em uma rede Ethernet e com uma conexão PPP com taxa de transmissão baixa.

Uma contribuição do sistema RMIRep é a integração de políticas de consistência variadas em um ambiente popular, que pode co-existir com aplicações de sistemas de informação já existentes. RMIRep estende a hierarquia Java RMI para fornecer a funcionalidade da replicação e consistência dos dados. Java RMI é um mecanismo de invocão remota de métodos que dá suporte a objetos Java distribuídos. A aceitação dessa tecnologia na indústria e o seu potencial para expansão foram cruciais na nossa decisão de adotá-la como sistema para o nosso projeto. 


\section{Abstract}

Advances in the technology of mobile computers, such as laptops and PDAs, have allowed access to a large number of distributed information systems. The use of these computers imposes several restrictions on the design and implementation of applications in high-latency networks, which must now deal with intermittent connectivity, frequent disconnections, and low data transmission rates. In particular, mobile computers must have access to the information even while disconnected.

Data replication is an attractive solution to allow access to distributed information systems in high-latency networks. In this thesis we investigate a weak-consistency policy called Bayou, developed at Xerox PARC. Weak-consistent replication allows any server to read and modify the data without requiring synchronization with other servers, and thus improves the availability of the information. Bayou is novel because it allows applications to control the degree of data availability, inconsistency, and the frequency of reconciliation with other servers. This is done through user policies, which can be tailored to a specific application domain.

We present the design and implementation of RMIRep, a system designed to aid in the development and analysis of consistency mechanisms. We implemented three consistency policies in RMIRep: independent replicas, totally synchronized replicas, and a variant of Bayou. We experimented with Bayou and with the the total synchronization policy in an Ethernet network, as well as with a PPP connection, in order to evaluate the system performance.

A contribution of RMIRep is the integration of a number of consistency policies in a popular framework, that can be used with the present information system applications. RMIRep provides replication and consistency of objects on top of Java RMI. Java RMI is a remote method invocation mechanism that provides support for distributed Java objects. The acceptance of Java RMI in the industry and its potential for expansion were crucial in our decision to adopt it as our base technology. 


\section{Sumário}

1 Introdução 1

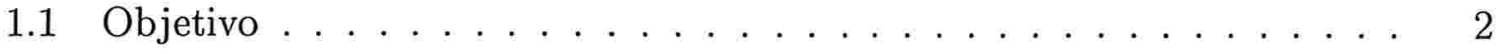

1.2 O Sistema RMIRep . . . . . . . . . . . . . . . . . 3

1.3 Organização da Dissertação . . . . . . . . . . . . . . . . . 3

2 Políticas de Consistência $\quad 5$

2.1 Política de Réplicas Independentes . . . . . . . . . . . . . 6

2.2 Política de Replicação com Consistência Total . . . . . . . . . . . . . . 6

2.3 Política de Consistência Bayou . . . . . . . . . . . . . . . 7

2.3.1 O Modelo de Sistema Básico do Bayou . . . . . . . . . . . . . 8

2.3.2 Detecção e Resolução de Conflitos . . . . . . . . . . . . . . . . . 9

2.3.3 O Protocolo Básico de Anti-entropia . . . . . . . . . . . . . . 10

2.3.4 Armazenagem Eficiente das Atualizações . . . . . . . . . . . . . 12

2.3.5 Ordens Causal e Total . . . . . . . . . . . . . . . . . . . . 15

2.3.6 Criação e Exclusão de Réplicas . . . . . . . . . . . . . . . . . 16

2.3 .7 Políticas de Usuário . . . . . . . . . . . . . . . . . . . . . . 17

2.3.8 Suporte para Domínios Específicos de Aplicação . . . . . . . . . 18

2.4 Outras Políticas de Consistência . . . . . . . . . . . . . . . . . . . . 21

3 O Sistema Java RMI 24

3.1 Chamada Remota de Procedimento . . . . . . . . . . . . . . 25

3.1.1 Estrutura do RPC . . . . . . . . . . . . . 25 
3.1.2 Transmissão de Parâmetros e Conversão de Dados . . . . . . . . 26

3.1 .3 Geração de Stubs . . . . . . . . . . . . . . . . . . 27

3.1 .4 Associação (Binding) . . . . . . . . . . . . . . . . 28

3.1 .5 Extensões do RPC . . . . . . . . . . . . . . . . . . . . 29

3.2 O Sistema Java RMI . . . . . . . . . . . . . . . . . . . . . . . . . . . 29

3.2 .1 Modelo de Sistema Básico . . . . . . . . . . . . . . . . . 30

3.2 .2 Coleta de Lixo Distribuída . . . . . . . . . . . . . . . . . . 33

3.2 .3 A Hierarquia de Classes . . . . . . . . . . . . . . . . 34

3.3 Contextualização do Java RMI na Literatura . . . . . . . . . . . . . . . 37

3.3 .1 Manta ..................... 37

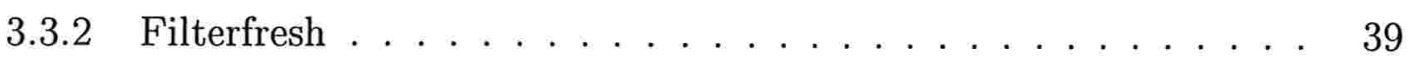

3.4 Alternativas para Java RMI . . . . . . . . . . . . . . . . . . . 40

4 O Sistema RMIRep $\quad 41$

4.1 Projeto Inicial: Integração no Nível da Camada de Referência Remota . 42

4.1 .1 Problemas no Projeto Inicial . . . . . . . . . . . . . . . . . . 44

4.2 Projeto Final: Integração no Nível da Camada de Aplicação . . . . . . 45

4.2 .1 A Hierarquia de Classes . . . . . . . . . . . . . . 45

4.2 .2 O Modelo Básico de Sistema . . . . . . . . . . . . . . . . . 48

4.3 Implementação das Políticas Total e de Réplicas Independentes . . . . 50

4.3.1 Política NoConsistency . . . . . . . . . . . . . . . . 50

4.3 .2 Política Total . . . . . . . . . . . . . . . 51

4.4 Mudança Dinâmica da Política de Consistência . . . . . . . . . . . 51

4.5 O Tradutor de Classes Remotas . . . . . . . . . . . . . . . . . 52

4.6 Restrições na Arquitetura de um ORR . . . . . . . . . . . . . . 53

4.7 Implementação da Política Bayou . . . . . . . . . . . . . . . . . 53

4.7 .1 O Conceito de Cliente e Servidor . . . . . . . . . . . . 53

4.7.2 O Modelo de Sistema Básico da Política Bayou . . . . . . . . . 54

4.7 .3 Detecção e Resolução de Conflitos . . . . . . . . . . . . . . . . . 55

4.7 .4 Sincronização . . . . . . . . . . . . . . . . . 57 
4.7.5 Desfazer e Refazer Operações (Roll backs) . . . . . . . . . . . . 57

4.7 .6 Visões Estável e Instável . . . . . . . . . . . . . . . . . 58

4.7 .7 O Log de Bayou . . . . . . . . . . . . . . . . . . . . . . . 59

4.7 .8 Políticas de Usuário . . . . . . . . . . . . . . . . . . . . . . . . . 59

5 Testes e Resultados $\quad 61$

5.1 A Estrutura e a Organização dos Testes . . . . . . . . . . . . . . . . . 62

5.2 Os Tempos de Execução da Política Total . . . . . . . . . . . . . . . 63

5.3 Os Tempos de Execução da Política Bayou . . . . . . . . . . . . . . . . 64

5.4 Comparação entre as Políticas Total e Bayou . . . . . . . . . . . . . . 68

5.5 Mudança Dinâmica da Política de Consistência . . . . . . . . . . . . . 69

6 Trabalhos Relacionados $\quad 71$

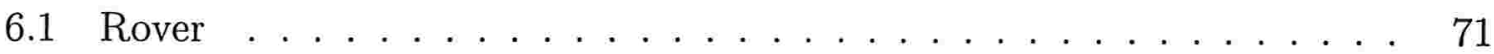

6.1.1 Arquitetura do Sistema . . . . . . . . . . . . . . . . 71

6.1 .2 Operação Desconectada . . . . . . . . . . . . . . . . 72

6.1 .3 Conectividade Fraca . . . . . . . . . . . . . . . . . . 73

6.1.4 Comparação entre Bayou e Rover . . . . . . . . . . . . . . . . . 73

6.2 Coda . . . . . . . . . . . . . . . . . . . . . 73

6.2 .1 Arquitetura do Sistema . . . . . . . . . . . . . . . 74

6.2 .2 Operação Desconectada . . . . . . . . . . . . . . . . 74

6.2 .3 Conectividade Fraca . . . . . . . . . . . . . . . . . . . . . . . . 74

6.2.4 Comparação entre Bayou e Coda . . . . . . . . . . . . . . . 75

6.3 Deno . . . . . . . . . . . . . . . . . . . . . . 75

6.3.1 Procedimentos de Comutatividade . . . . . . . . . . . . . 75

6.3.2 Estabilização de Atualizações . . . . . . . . . . . . . . 76

6.3.3 Alocação do Valor de Circulação . . . . . . . . . . . . . . . . 77

6.3.4 Comparação entre Bayou e Deno . . . . . . . . . . . . . . 77

6.4 Outros sistemas . . . . . . . . . . . . . . . . . . . . 78 
A Definição das Interfaces da Política de Consistência Bayou 83

A.1 Interface BayouClientInterface . . . . . . . . . . . . . 83

A.2 Interface Bayou . . . . . . . . . . . . . . . . 86 


\section{Lista de Figuras}

2.1 Classificação de políticas de consistência . . . . . . . . . . . . . 5

2.2 Processamento de uma atualização Bayou . . . . . . . . . . . . . . . 9

2.3 Exemplo de uma atualização Bayou . . . . . . . . . . . . . . . . . . . . 10

3.1 Componentes da arquitetura de RPC . . . . . . . . . . . . . 26

3.2 Interação típica entre um cliente e servidor RMI . . . . . . . . . . . . . 31

3.3 Arquitetura de alto-nível do RMI . . . . . . . . . . . . . . . . . . . . . 31

3.4 Uma invocação típica a um objeto remoto . . . . . . . . . . . . . . . 33

3.5 Hierarquia parcial de classes do RMI . . . . . . . . . . . . . . . 34

3.6 Interoperabilidade entre Manta e uma JVM . . . . . . . . . . . . . . . 38

4.1 Hierarquia de classes original do RMIRep . . . . . . . . . . . . . . . . . 43

4.2 Hierarquia de classes do RMIRep . . . . . . . . . . . . . . . . . 46

4.3 Tradução automática de classes remotas . . . . . . . . . . . . . . . 48

4.4 Um ORR com política de consistência total . . . . . . . . . . . . 50

4.5 O protocolo de anti-entropia . . . . . . . . . . . . . . 55

4.6 Atualização com suporte para resolução e detecção de conflitos . . . . . 56

4.7 Atualização sem suporte para resolução e detecção de conflitos . . . . . 56

4.8 Reordenação de atualizações durante anti-entropia . . . . . . . . . . . . 58

5.1 Política Total na Ethernet . . . . . . . . . . . . . . . . . . . . . . 64

5.2 Execução de anti-entropia como função do número de réplicas . . . . . 65

5.3 Análise de anti-entropia com o fator da rede . . . . . . . . . . 65 
5.4 Análise de anti-entropia com o fator da rede . . . . . . . . . . . 66

5.5 Anti-entropia com servidores de identificadores máximas . . . . . . . . 67

5.6 Comparação entre o desempenho das políticas Total e Bayou . . . . . . 68

5.7 Mudança da política de consistência com PPP . . . . . . . . . . . . 70

6.1 A arquitetura de Rover . . . . . . . . . . . . . . . . . . . . 72

6.2 Estabilização de atualizações através de valores de circulação . . . . . . 77 


\section{Capítulo 1}

\section{Introdução}

O cotidiano de muitas pessoas tem sido transformado pelos avanços técnicos no desenvolvimento de computadores móveis, como notebooks e PDAs (Personal Digital Assistants), que requerem comunicação via redes sem fio e pela acelerada queda de preços desses componentes. Esses avanços permitirão o acesso a informações sobre o trânsito de uma determinada região da cidade, a verificação dos horários atualizados de vôos e das condições do tempo em outra cidade, o acesso a preços de instrumentos financeiros e a informações dependentes de localização (location-dependent), como, por exemplo, onde está o táxi mais próximo [32].

Sistemas de informação em redes de alta latência, acessados por computadores móveis, impõem várias restrições ao sistema distribuído correspondente. Os dados acessados pelos clientes devem estar disponíveis, ainda que não integralmente, na presença de falha de alguns dos servidores. Também é necessário que o sistema forneça suporte para acesso simultâneo aos dados por um grande número de usuários. Além disso, o tempo de resposta de uma requisição do cliente deve ser pequeno e o sistema deve ser capaz de funcionar em uma rede de baixa largura de banda, onde erros de transmissão ocorrem frequentemente [24].

Em alguns tipos de ambientes, como o de computadores móveis, a replicação dos dados pode ser a única alternativa viável para disponibilizar serviços às aplicações usuárias. Em tais ambientes, a desconexão de computadores móveis é um acontecimento inevitável, devido a vários fatores: o tráfego dos usuários desses aparelhos em lugares como túneis ou cidades que estejam fora do alcance de operadoras de rede, o alto custo financeiro de acessar redes de largura com banda baixa e também a fonte de energia limitada desses computadores.

As características dos computadores móveis citadas sugerem que os dados sejam distribuídos e replicados em unidades geograficamente dispersas. Em muitos casos, gerenciadores de bancos de dados distribuídos não resolvem o problema pois, embo- 
ra lidem com a distribuição, podem não se adequar a outros requisitos da aplicação, como balanceamento elevado de carga, elevada taxa de utilização e semântica transacional específica para um domínio. Conseqüentemente, em muitos casos, aspectos de replicação e consistência devem ser tratados diretamente por essas aplicações.

\subsection{Objetivo}

Nessa dissertação trataremos do problema da replicação de dados em sistemas de informação em redes de grande acesso, tal como a Internet. Replicação de dados entre réplicas é uma solução atraente para disponibilização eficiente de dados em redes de alta latência. No entanto, ela introduz o problema da inconsistência dos dados: a informação replicada precisa ser mantida consistente com relação às outras réplicas. A maneira específica pela qual essa consistência é alcançada é definida pela política de consistência dos dados. Ela define, entre outras coisas, a frequência com a qual os dados são reconciliados, o número mínimo de servidores que devem participar da sessão de reconciliação e, caso não seja necessário que todos eles estejam presentes, os servidores escolhidos para realizar essa reconciliação.

A escolha da política de consistência depende intimamente das necessidades da aplicação. Nos últimos anos, políticas de consistência fraca ${ }^{1}$ têm despertado o interesse de acadêmicos e da indústria por causa da flexibilidade que esses sistemas oferecem a aplicações usuárias quanto à propagação dos dados. Em particular, as aplicações usuárias passam a ter controle de quando fazer a reconciliação de dados e com que servidores elas desejam fazer essa reconciliação, além da quantidade de dados a ser reconciliada. Essa liberdade permite que aplicações com domínios distintos se utilizem dos mesmos mecanismos de replicação. Políticas de consistência fraca oferecem vantagens que as qualificam como ótimas candidatas para a replicação de dados em sistemas de informação acessados por computadores móveis.

O objetivo dessa dissertação é investigar um sistema de replicação adequado para o tipo de rede em questão. Desenvolvemos uma política de consistência fraca, baseada no sistema Bayou $[5,64,74]$, para ser a principal política do nosso sistema. Bayou foi desenvolvido no Xerox PARC (Palo Alto Research Center) e é baseado na reconciliação de dados entre pares de réplicas. Ele provê suporte para progresso na presença de falhas de servidores e é adequado para uso em redes com largura de banda limitada. Bayou é apresentado detalhadamente no próximo capítulo.

\footnotetext{
${ }^{1}$ Políticas de replicação com consistência fraca permitem que servidores distintos leiam e modifiquem dados sem haver coordenação contínua e explícita entre eles. Essas políticas asseguram que todos os servidores vão tomar conhecimento dessas modificações em algum momento no futuro, ainda que, em certos instantes, é possível que o estado de dois servidores quaisquer não estejam consistentes.
} 


\subsection{O Sistema RMIRep}

Embora inúmeras políticas de replicação e consistência fraca venham sendo estudadas e implementadas em ambientes específicos ou pouco conhecidos [29, 32, 33, 37], seria de grande proveito integrar algumas delas em um ambiente popular, que pudesse co-existir com aplicações de sistemas de informação já existentes. Um ótimo candidato para essa integração é o sistema Java [1,39] e o mecanismo de invocação remota de métodos (RMI $[57,76,78]$ ) que Java oferece. Java e Java RMI são tecnologias que facilitam a construção de aplicações distribuídas em ambientes de rede e plataformas heterogêneos (através do suporte fornecido pelas hierarquias java.rmi.* e java.rmi.server.*, ferramenta rmic e serviço rmiregistry). A aceitação dessas tecnologias na indústria e o seu potencial para expansão foram cruciais na nossa decisão de adotá-las como sistema para o nosso projeto. Além disso, a heterogeneidade que Java provê facilita o desenvolvimento de sistemas para redes de computadores móveis, visto que essas redes são compostas por diversas plataformas e tipos de conexão.

Nessa dissertação apresentamos o RMIRep, um sistema baseado no Java RMI que fornece suporte para a replicação de objetos. RMIRep foi projetado para uso em redes de grande acesso, compostas por possivelmente centenas de usuários espalhados pelo mundo. Sua principal funcionalidade é permitir que uma aplicação decida a política de consistência de réplicas a ser usada, dentre as disponíveis. Essa política pode ser mudada em tempo de execução. Além disso, RMIRep pode ser usado como um arcabouço para o desenvolvimento e a análise de novas políticas de consistência.

A principal facilidade oriunda desse sistema é a semi-transparência: o usuário constrói a aplicação sem considerar se os objetos serão replicados ou não. Réplicas têm impacto na latência da execução dos métodos, que pode ser positivo (devido à disponibilização de serviços pelas réplicas, diminuindo a disputa por um mesmo objeto e reduzindo os custos de acesso e tráfego na rede), ou negativo (pela necessidade de manter as réplicas consistentes). Uma vez que a política de consistência seja definida, todo o mecanismo de replicação fica escondido do usuário.

\subsection{Organização da Dissertação}

Essa dissertação está organizada da seguinte forma: no capítulo 2 apresentamos a políticas de consistência total, a de réplicas independentes e a política Bayou. Além disso, discutimos algumas políticas de consistência que não foram implementadas no RMIRep mas que têm recebido destaque na literatura. No capítulo 3 apresentamos o mecanismo de chamada remota de procedimentos (RPC) e o sistema Java RMI. No capítulo 4 apresentamos o sistema RMIRep: 
- A hierarquia de classes;

- A implementação das políticas de consistência;

- Uma discussão sobre a integração da funcionalidade do RMIRep ao sistema Java RMI;

- O modelo de funcionamento da mudança dinâmica da política de consistência;

- O tradutor automático de classes remotas.

No capítulo 5 analisamos os testes realizados com as políticas de consistência total e Bayou. No capítulo 6 discutimos trabalhos relacionados e futuras linhas de pesquisa e apresentamos as conclusões do nosso trabalho no capítulo 7. 


\section{Capítulo 2}

\section{Políticas de Consistência}

Esse capítulo descreve o modelo das políticas de consistência investigadas nesse trabalho: réplicas independentes, total e Bayou. O contexto da replicação de dados empregado por nós é o mesmo usado por Wiesmann et al. [77]: um sistema composto por um grupo de réplicas sobre as quais atualizações são realizadas por clientes. $\mathrm{O}$ termo grupo de réplicas é usado nessa dissertação para denotar um conjunto de réplicas que são mantidas consistentes e não envolve conceitos relacionados com o tópico de comunicação de grupo [15]. Concluímos o capítulo descrevendo algumas políticas de consistência que não foram implementadas no RMIRep, mas que têm recebido destaque na literatura.

Gray et al. [27] classificam políticas de consistência de acordo com dois parâmetros, como mostra a figura 2.1. Um dos parâmetros é em quais réplicas atualizações podem ser geradas (cópia primária versus update-everywhere) e o segundo é quando a propagação de atualizações acontece (replicação forte (eager) versus fraca (lazy)). Todas as políticas de consistência implementadas no RMIRep são do tipo update-everywhere, mas diferem quanto à rapidez com que as atualizações são propagadas. Políticas que

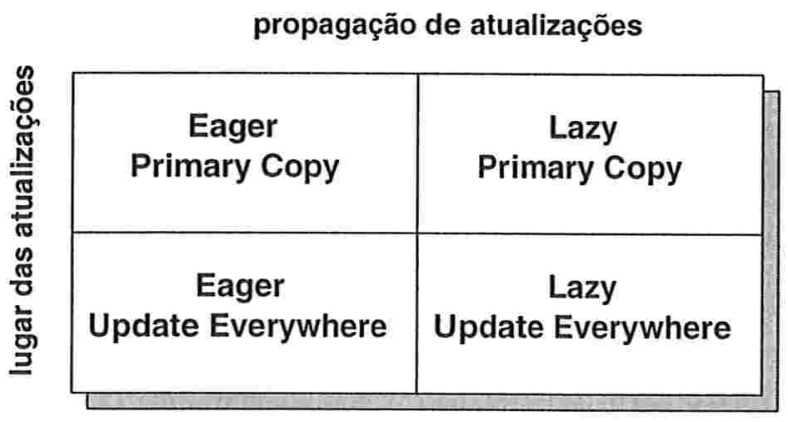

Figura 2.1: Classificação de políticas de consistência 
implementam consistência fraca sacrificam a consistência total entre as réplicas em favor de uma disponibilidade de acesso aos dados maior, enquanto que as políticas de consistência forte mantém as réplicas completamente consistentes em detrimento da eficiência de acesso. De acordo com essa classificação, as políticas Bayou e de réplicas independentes são fracas, enquanto que a política total é forte.

\subsection{Política de Réplicas Independentes}

Uma possibilidade para suporte à replicação é manter réplicas totalmente independentes, não garantindo nenhuma consistência de dados. Nesse esquema, um servidor pode alterar qualquer unidade de informação (no caso de sistemas distribuídos orientados a objetos, essa unidade equivale a um objeto) sem necessitar comunicar essa mudança a nenhum outro servidor. Lenz [48] classifica essa técnica como uma política com predicado de consistência fraca sem requisitos.

Essa política pode ser útil em sistemas que não requerem reconciliação entre réplicas após a execução de operações. Um exemplo seria um banco de dados que armazenasse informações imutáveis, como o código de uma interface gráfica, por exemplo. Clientes podem ter alta confiança nos dados desse tipo de sistema, já que alterações raramente são efetuadas no seu conteúdo. Além do mais, é essencial que a latência das operações seja a mínima possível; justamente o que a política oferece. Em geral, no entanto, a política de réplicas independentes não é adequada a sistemas de informação replicados, uma vez que ela não oferece nenhum mecanismo para a convergência dos estados das réplicas.

\subsection{Política de Replicação com Consistência Total}

A política de consistência total mantém todas as réplicas disponíveis completamente sincronizadas. Todas as atualizações feitas por clientes em alguma das réplicas são propagadas a todas as réplicas disponíveis, de modo a produzir uma execução serializável $^{1}$ de atualizações (one-copy serializability [18]), eliminando conflitos decorrentes da concorrência de dados. Serialização ordena todas as atualizações do sistema de uma maneira global e, portanto, cada réplica mantém exatamente a mesma visão do banco de dados. Dessa maneira, a execução serializável de atualizações simula, do ponto de vista do usuário, o funcionamento de um banco de dados com uma cópia única $[4,7]$. Apresentamos a seguir a definição da política de consistência total.

\footnotetext{
${ }^{1} \mathrm{O}$ termo serializável é usado nessa dissertação para denotar o termo em inglês serializable. Similarmente, os termos serialização, serializado, desserializado, serializador e desserializador referem-se às palavras serialization, serialized, deserialized, serializer e deserializer.
} 
Considere uma unidade de informação $x$ e servidores $Y_{1}, Y_{2}, \ldots, Y_{n}$ onde $x$ encontrase replicada. A política de consistência total nos assegura que, assim que ocorrer uma mudança relativa a $x$ no banco de dados de qualquer um dos servidores $Y_{i}, 1 \leq i \leq n$, ou seja, assim que $Y_{i}(x)$ mudar, essa mudança ocorrerá em todos os outros servidores $Y_{j}, 1 \leq j \leq n, j \neq i$. Além disso, enquanto o novo valor de $Y_{i}(x)$ não for propagado para os outros servidores $Y_{k}, Y_{k}(x), \forall k$ estará indisponível caso ocorra alguma chamada local requisitando o valor dessa unidade de informação.

No caso de objetos distribuídos que não representam bancos de dados, as unidades de informação são objetos, que são modificados através de métodos. A semântica da consistência total nesses sistemas é similar: dados um objeto $o$ e réplicas $o_{1}, o_{2}, \ldots, o_{n}$ desse objeto nos servidores $Y_{1}, Y_{2}, \ldots, Y_{n}$, assim que um método $m$ for executado em $o_{i}, 1 \leq i \leq n, m$ é executado em $o_{j}, 1 \leq j \leq n, j \neq i$. Além disso, enquanto $m$ não for executado em todas as réplicas de $o, o_{k}, \forall k$ estará indisponível para invocações locais.

A política de consistência total garante o maior grau de consistência possível, dando aos usuários a garantia de que os dados de um servidor estão consistentes com os demais servidores. Por outro lado, as latências das operações nesse sistema podem ser muito altas, já que para cada modificação de um objeto em um servidor são necessárias várias chamadas a servidores remotos para realizar a sincronização dos dados.

Existem aplicações que estão dispostas a pagar um preço de consistência mais alto para obter informações atualizadas de um certo objeto. Por exemplo, na aplicação de referência do projeto SIDAM [17], onde usuários móveis podem se manter informados sobre as condições de trânsito de uma grande metrópole, existem tipos de serviço, como ambulâncias ou carros de bombeiro que, em certos momentos, se beneficiariam de informação mais atualizada sobre as condições do trânsito da cidade. Para essas aplicações, a atualidade dos dados é de vital importância. No entanto, a política de consistência total é inadequada para redes de alta latência onde os objetos são alterados com muita freqüência, pois nesse caso os servidores precisariam comunicar muitos dados entre si, requerendo uma largura de banda alta, característica ausente em redes de alta latência.

\subsection{Política de Consistência Bayou}

O sistema Bayou $[5,64,74]$ é um conjunto de clientes, servidores (também chamados de réplicas) e protocolos para armazenagem de dados replicados com consistência fraca. Ele foi projetado para oferecer suporte a usuários que não podem ou não desejam estar continuamente conectados, como é o caso de computadores móveis.

Embora Bayou faça distinção entre clientes e servidores [21], é esperado que computadores móveis funcionem de acordo com um modelo ponto-a-ponto (peer-to-peer), 
servindo como clientes para algumas aplicações e como servidores para outras.

Para maximizar a disponibilidade dos dados, Bayou permite que um cliente acesse e modifique qualquer réplica acessível dos dados. Bayou fornece mecanismos que permitem à aplicação usuária detectar e resolver possíveis conflitos automaticamente. Para garantir consistência entre as réplicas, um servidor Bayou deve ser capaz de desfazer (roll back) os efeitos de atualizações já executadas para poder reordená-las e reexecutá-las de acordo com uma ordem global de serialização.

\subsubsection{O Modelo de Sistema Básico do Bayou}

Cada servidor mantém um log de atualizações (writes) e um banco de dados cujo conteúdo reflete a execução ordenada de cada atualização. No contexto do Bayou, uma atualização é um procedimento que gera um conjunto de mudanças no banco de dados. Nós apresentamos os componentes de uma atualização e como eles são usados para prover um mecanismo de deteç̧ão e resolução automática de conflitos na sessão 2.3.2.

Bayou apresenta um algoritmo de reconciliação de dados simples e flexível, chamado de anti-entropia ${ }^{2}$. Reconciliação de dados é o processo pelo qual dois servidores que possuem réplicas distintas de um mesmo banco de dados comunicam entre si as atualizações realizadas em cada réplica, de modo a produzir uma visão idêntica do estado do banco de dados em cada servidor. O protocolo de anti-entropia é baseado na comunicação entre pares de réplicas e na propagação ordenada de atualizações e é apresentado em detalhe na sessão 2.3.3.

Quando um cliente executa uma atualização em um servidor, ela é marcada com um accept-stamp monotonicamente crescente e inserida no log da réplica. Accept-stamps podem ser timestamps structs ou números inteiros. Cada servidor possui o seu próprio gerador de accept-stamps, ou seja, é possível que servidores distintos gerem acceptstamps iguais. Quando uma atualização é propagada por anti-entropia, ela carrega consigo o seu accept-stamp e o identificador do servidor onde ela foi originada. Acceptstamps definem uma ordem parcial sobre todas as atualizações do sistema, chamada de ordem de aceitação (accept-order), onde uma atualização $a$ antecede uma atualização $b$ se ambas foram originadas no mesmo servidor e o accept-stamp de $a$ é menor do que o de $b$.

Propagar as atualizações segundo a ordem de aceitação permite que Bayou mantenha a propriedade prefixo que define que um servidor, ao aceitar uma atualização $a$ do servidor $X$, já deve ter recebido todas as atualizações previamente aceitas por $X$. Essa propriedade permite que vetores de versão (version vectors) sejam usados para representar todas as atualizações já recebidas por um servidor. Em Bayou, o vetor

\footnotetext{
${ }^{2}$ Entropia significa a medida da quantidade de desordem de um sistema, de acordo com o Novo Dicionário Aurélio da Língua Portuguesa [19].
} 


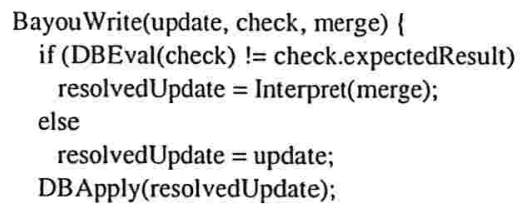

Figura 2.2: Processamento de uma atualização Bayou [74]

de versão de um servidor $X$ possui entradas para todas as réplicas que $X$ conhece e armazena accept-stamps de atualizações em suas entradas. Especificamente, o índice de $X$ no vetor de versão do servidor $Y, Y . V(X)$, é o maior accept-stamp de qualquer atualização conhecida por $Y$ originada em $X$.

\subsubsection{Detecção e Resolução de Conflitos}

Bayou foi projetado para fornecer suporte para a detecção e resolução de conflitos específicos à aplicação usuária. A aplicação é responsável por definir a noção de um conflito, além de especificar o procedimento para resolvê-lo. Bayou, por sua vez, é responsável por detectar e resolver conflitos automaticamente, de acordo com as definições dadas pela aplicação usuária. Uma discussão da interface para a definição desses procedimentos encontra-se na sessão 2.3.8.

Bayou inclui dois mecanismos para detectar e resolver conflitos automaticamente: procedimentos check e merge (dependency checks e merge procedures, respectivamente). Eles foram projetados para atender às necessidades de um amplo espectro de aplicações e permitem à aplicação usuária definir a noção de um conflito e o algoritmo que deve ser executado caso um conflito seja detectado.

Uma atualização é composta por três partes: um procedimento check, que verifica se a atualização introduz um conflito de dados no sistema, um procedimento merge, que é executado caso um conflito seja detectado e um procedimento update, que é uma operação que modifica ou lê o banco de dados e que é executada caso não haja um conflito. A figura 2.2 mostra como uma atualização é processada por Bayou. Cada atualização define um procedimento check, que é executado sobre a cópia local dos dados. Se check retornar o valor esperado, nenhum conflito foi detectado e portanto update é executado. Caso contrário, o servidor invoca o procedimento merge para resolver o conflito, como mostrado na figura 2.2. Merge é escrito em uma linguagem de alto-nível e é responsável por produzir um novo update para ser executado sobre o banco de dados. Quando a resolução automática do conflito não for possível, espera-se que merge registre essa ocorrência em um log de erros para que ele possa ser resolvido posteriormente com intervenção humana. Tal convenção, no entanto, é específica à 


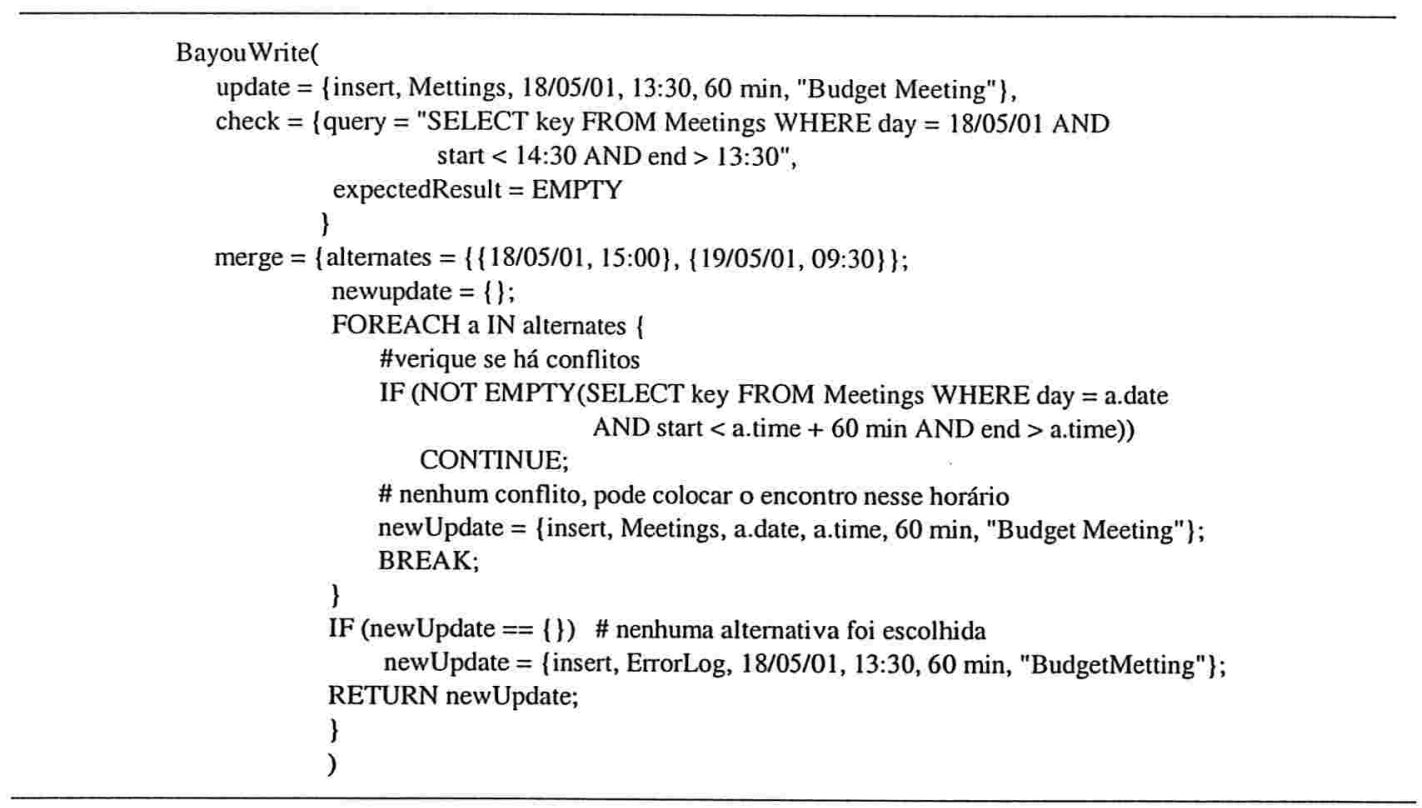

Figura 2.3: Exemplo de uma atualização Bayou para um programa de reserva de salas para reuniões [74]

aplicação usuária. A figura 2.3 mostra um exemplo de uma atualização para uma aplicação que reserva salas para reuniões.

\subsubsection{O Protocolo Básico de Anti-entropia}

O objetivo do protocolo de anti-entropia é reconciliar o estado de duas réplicas, ou seja, fazer com que elas tenham o mesmo conjunto de atualizações no seu log. O protocolo de anti-entropia possui os seguintes atributos e vantagens:

- Suporte para topologias de comunicação arbitrárias: o protocolo provê mecanismos para que atualizações possam ser propagadas entre qualquer par de réplicas. A teoria das epidemias (theory of epidemics) garante que essas atualizações serão propagadas para o restante do sistema [20];

- Consistência é sempre alcançada: cada atualização alcança todos os servidores. Servidores que tenham recebido as mesmas atualizações têm o mesmo conteúdo nos seus bancos de dados;

- Progresso incremental: o protocolo provê progresso mesmo que haja interrupções ou falhas temporárias na rede ou em alguns dos servidores (possivelmente todos); 
- Operações em redes de largura de banda baixa: o protocolo é baseado na troca de atualizações, ao invés de na transmissão do estado completo do banco de dados. Além disso, somente atualizações que a réplica receptora desconhece são propagadas;

- Armazenagem eficiente de dados: o protocolo permite que réplicas descartem atualizações guardadas no seu log para recuperarem o espaço de armazenagem usado nas sessões de reconciliação;

- Gerenciamento "leve" (lightweight) de grupos dinâmicos de réplicas: O protocolo permite a criação e remoção de réplicas através da comunicação com apenas uma réplica disponível;

- Escolha arbitrária de políticas de usuário: o protocolo dá suporte a qualquer política para a escolha da réplica com a qual se pretende fazer a reconciliação e para a escolha da freqüência com a qual as réplicas se reconciliam. A única restrição é que as políticas precisam garantir que haverá, em algum momento, um trajeto de comunicação ${ }^{3}$ entre qualquer par de réplicas do sistema.

O protocolo de anti-entropia se baseia em três decisões básicas de projeto:

1. É uma interação unidirecional entre pares de servidores;

2. Ocorre através da propagação de atualizações;

3. A propagação de atualizações é restrita pela ordem de aceitação.

Comunicação entre pares de servidores permite que eles reconciliem seus dados independentemente do tipo de conexão entre eles e da disponibilidade de outros servidores. O protocolo se baseia na teoria das epidemias para garantir que as atualizações sejam propagadas para todas as réplicas.

A razão pela qual o protocolo propaga atualizações ao invés do conteúdo inteiro do banco de dados é porque o processo de deteç̧ão e resolução de conflitos do Bayou (sessão 2.3.2) requer que todas as atualizações sejam processadas em cada réplica. Além disso, há outras vantagens em propagar atualizações ao invés de todo o conteúdo do banco de dados:

- O montante de informação enviado é menor, a não ser que o nível de atividade nos servidores seja muito alto. Nesse caso o tamanho total das atualizações enviadas é maior do que o banco de dados;

\footnotetext{
${ }^{3} \mathrm{Não}$ há necessidade de que todas as réplicas que fazem parte desse trajeto estejam conectadas simultaneamente.
} 
- Evita-se ambigüidades oriundas da criação e deleção de objetos (unidades de informação): quando um servidor recebe o novo estado de um objeto que ele não possui no seu banco de dados, ele não consegue identificar se o objeto é novo ou se já não está mais presente por ter sido removido.

O protocolo é simples e envolve duas réplicas: um remetente $(X)$ e um receptor $(Y)$. O vetor de versão de $Y, Y . V$, é enviado a $X$ e este percorre o seu $\log$ apenas uma vez, enviando todas as atualizações desconhecidas (identificadas como explicamos a seguir) por $Y$. O protocolo é incremental, ou seja, a reconciliação entre as duas réplicas progride mesmo que o protocolo seja interrompido em qualquer das suas fases por causa de desconexões ou de falhas na rede.

Considere uma atualização $a$ gerada em um servidor qualquer $Z$, armazenada no $\log$ de $X$. $X$ descobre se o receptor $Y$ desconhece $a$ comparando o accept-stamp de a com o accept-stamp armazenado na posição $Y . V(Z)$ do vetor de versão de $Y$. Se o accept-stamp de $a$ for menor ou igual ao de $Y . V(Z)$, então $Y$ possui a atualização $a$, caso contrário, $Y$ ainda não a processou.

Assim que uma atualização é recebida, ela pode ser executada e inserida no log do receptor, já que a réplica remetente terá enviado todas as atualizações necessárias para que a propriedade prefixo seja satisfeita no receptor. Em uma futura sessão de anti-entropia, essa atualização não será propagada pela réplica remetente e somente as atualizações desconhecidas pelo receptor serão enviadas.

O protocolo garante que cada atualização alcançará todas as réplicas sem exigir que mais do que duas delas estejam simultaneamente conectadas. Para isso, é necessário que haja, em algum momento, um trajeto de comunicação entre qualquer par de réplicas do sistema.

\subsubsection{Armazenagem Eficiente das Atualizações}

Atualizações devem ser descartadas periodicamente do log para que as réplicas retomem o espaço de armazenagem usado pelas sessões de reconciliação. Isso é ainda mais necessário para alguns computadores móveis, como palmtops, que possuem espaço de armazenagem limitado. Muitos computadores móveis fabricados hoje em dia, como laptops, possuem amplo espaço de armazenagem, da ordem de gigabytes e, portanto, não impõem restrições tão fortes ao sistema como era o caso em meados da década de 90, quando Bayou foi projetado. Ainda assim, não é razoável exigir que aplicações usuárias armazenem logs de tamanho indefinidamente crescente e por isso mecanismos para exclusão de atualizações precisam ser fornecidos.

Bayou adota uma política pela qual cada servidor decide quantas atualizações precisam ser removidas do seu log. Somente atualizações estáveis (como explicado a se- 
guir) podem ser excluídas. A remoção precipitada de atualizações pode ocasionar uma transferência integral do banco de dados de um servidor, como é o caso quando duas réplicas altamente inconsistentes ${ }^{4}$ executarem o protocolo, pois, nesse caso, as atualizações necessárias para uma das réplicas podem já ter sido excluídas. Há, portanto, um compromisso entre o espaço local de armazenagem e o custo de atualização de réplicas altamente inconsistentes.

\section{Estabilidade das Atualizações}

Bayou adota um modelo que estabiliza atualizações através de uma réplica primária. Ao contrário de sistemas que exigem quóruns de réplicas [42], o processo de estabilização adotado por Bayou não é afetado por desconexões demoradas de algumas das réplicas. A réplica primária estabiliza uma atualização quando a vê pela primeira vez, marcandoa com um commit sequence number (CSN) monoticamente crescente ${ }^{5}$. O CSN de uma atualização instável tem o valor de $\infty$. O CSN e o accept-stamp definem uma nova ordem parcial sobre todas as atualizações do sistema, a ordem estável, definida da seguinte maneira para duas atualizações $a$ e $b$ quaisquer (AS significa o accept-stamp de uma atualização):

$$
a<b \text { se }\left\{\begin{array}{l}
a \cdot \mathrm{CSN}<b . \mathrm{CSN} \text { ou } \\
a \cdot \mathrm{CSN}=b . \mathrm{CSN}=\infty \quad \text { e } \quad a . \mathrm{AS}<b . \mathrm{AS} \quad \text { e } \quad a \cdot \text { serverId }=b . \text { serverId }
\end{array}\right.
$$

A relação 2.1 define que a atualização $a$ antecede a atualização $b$ se o CSN de $a$ for menor do que o de $b$, ou se ambas forem instáveis e tiverem sido originadas no mesmo servidor e o accept-stamp de $a$ for menor do que o de $b$.

As atualizações estáveis são totalmente ordenadas entre si, vêm antes de qualquer atualização instável e, portanto, nunca precisam ser reordenadas. Quando uma réplica não-primária descobre que uma atualização se tornou estável, essa atualização se torna estável nessa réplica, uma vez que ela já vai ter recebido todas as outras atualizações com CSNs menores.

Ao contrário de sistemas de consistência fraca onde atualizações só podem ser realizadas em réplicas primárias (ver sessão 2.4), Bayou tolera falhas temporárias na réplica primária sem que isso impeça aplicações usuárias de fazerem progresso. A incapacidade de uma réplica de se comunicar com a réplica primária não a impede de ler e atualizar

\footnotetext{
${ }^{4} \mathrm{O}$ termo altamente inconsistente é usado informalmente para caracterizar uma grande divergência no estado de duas réplicas. Similarmente, o termo altamente consistente é usado para denotar réplicas cujos estados estão convergentes (não necessariamente de acordo com os critérios de one-copy-serializability).

${ }^{5}$ Embora [64] não defina o formato do CSN, ele pode ser um número inteiro.
} 
seus dados. As atualizações geradas nessa réplica simplesmente permanecem instáveis até serem aceitas pela réplica primária. [74] não define o comportamento do sistema caso a réplica primária falhe permanentemente.

\section{Propagação de Atualizações Estáveis}

A porção do $\log$ de um servidor que corresponde a atualizações estáveis pode ser representada usando o maior CSN presente no log.

Para propagar as atualizações estáveis, o protocolo percorre a porção do log do remetente correspondente a essas atualizações e as envia ao receptor caso este não as possua. É possível que o receptor possua alguma dessas atualizações, mas que desconheça o seu CSN (ou seja, a atualização ainda é instável no receptor, mas já foi estabilizada no remetente). Nesse caso o remetente propagará somente uma notificação indicando o CSN da atualização correspondente. Após essa etapa, o protocolo executa como descrito na sessão 2.3.3, atravessando o $\log$ do remetente e propagando todas as atualizações instáveis desconhecidas pelo receptor.

\section{Exclusão de Atualizações do $\log$}

O protocolo de anti-entropia permite que uma réplica exclua qualquer prefixo correspondente a atualizações estáveis do seu $\log$.

Durante uma sessão de anti-entropia, o remetente precisa verificar se o receptor precisa de atualizações que já foram excluídas do seu log. Para isso, cada servidor mantém um ommitted sequence number (OSN), cujo valor é o maior CSN das atualizações excluídas. Durante uma sessão de anti-entropia, o remetente compara seu OSN com o CSN do receptor: se o OSN for maior, então o receptor necessita de uma transferência do conteúdo completo do banco de dados. Há duas observações a serem feitas sobre tal transferência. Primeiro, a largura de banda necessária para essa operação geralmente é maior do que a necessária para propagar atualizações. Segundo, essa transferência não é uma operação incremental: todo o banco de dados precisa ser propagado para que ela tenha êxito.

\section{Desfazer Atualizações}

Há duas situações nas quais atualizações armazenadas no log dos servidores precisam ser desfeitas (rolled back): no remetente, quando uma transferência completa do banco de dados é necessária e no receptor quando, durante uma sessão de anti-entropia, ele recebe atualizações que têm uma posição menor do que as existentes no seu log. 
Desfazer atualizações no remetente deve ser uma operação rara, enquanto que no receptor isso deve acontecer no máximo uma vez por sessão de anti-entropia. No último caso, há duas otimizações que podem reduzir ainda mais a freqüência dessa operação. Primeiro, se uma réplica estiver envolvida em várias sessões de anti-entropia com servidores remotos, o log só precisa ser desfeito uma vez, até a posição da atualização recebida que possui o menor accept-stamp. Segundo, as atualizações desfeitas não precisam ser refeitas até que o cliente deseje ler o conteúdo do banco de dados. Portanto, há um compromisso em diminuir o custo de sessões consecutivas de anti-entropia e a latência de uma requisição feita pelo cliente. Uma solução seria calcular o intervalo de tempo médio entre requisições do cliente e, após uma sessão de anti-entropia, refazer as atualizações desfeitas após esse intervalo.

\subsubsection{Ordens Causal e Total}

Além da ordem parcial de propagação imposta pela propriedade prefixo, Bayou possui dois outros requisitos de ordenação: ordem causal, para fornecer garantias em uma sessão (session guarantees) e ordem total, para garantir consistência entre as réplicas.

Garantias de sessão diminuem as inconsistências observadas por clientes devido à comunicação com servidores diferentes. Uma breve descrição de garantias de sessão em Bayou encontra-se na sessão 2.3.8. Uma discussão mais detalhada encontra-se em [75]. No entanto, no que diz respeito ao protocolo de anti-entropia, garantias de sessão exigem que as atualizações sejam propagadas obedecendo a uma ordem causal, que especifica que uma atualização $a$ precede uma atualização $b$ se e somente se no momento em que $b$ foi aceita por um servidor, $a$ já havia sido aceita. Bayou implementa a ordem causal por meio de timestamps, que são atribuídos às atualizações quando elas são aceitas pela primeira vez por um servidor. Para isso, cada servidor mantém um relógio lógico [47] que avança quando novas atualizações são geradas por clientes, ou quando atualizações com timestamps maiores são aceitas por meio de anti-entropia. Por causa disso, uma nova atualização aceita por um servidor terá um timestamp maior do que todas as já existentes nesse servidor e por isso será ordenada depois delas. Nenhuma alteração precisa ser feita no protocolo de anti-entropia para acomodar a ordenação causal, já que ela define requisitos mais fortes do que os da ordem de aceitação e não altera a propriedade prefixo. Além disso, propagar atualizações na ordem causal faz com que essa ordem seja válida em todos os servidores.

A ordem total é necessária para que réplicas que possuam as mesmas atualizações tenham o mesmo conteúdo nos seus bancos de dados. A ordem estável introduzida na sessão 2.3 .4 garante essa propriedade para atualizações estáveis. No entanto é importante que, em sistemas de consistência fraca, essa propriedade também seja válida para as atualizações instáveis. A ordem de aceitação pode ser facilmente convertida 
à ordem total usando o identificador do servidor que gerou a atualização: acceptstamps são usados para implementar a ordem causal descrita acima e os identificadores dos servidores são usados para desempatar atualizações com accept-stamps iguais. A ordem estável também pode ser convertida à ordem total. Para isso, três componentes são usados: $\langle C S N$, accept-stamp, identificador do servidor $\rangle$, com o CSN sendo o fator mais significativo e o identificador do servidor sendo usado somente para desempatar atualizações com accept-stamps iguais. Da mesma maneira que a ordem causal, a ordem total pode ser usada sem nenhuma alteração no protocolo de anti-entropia. Além disso, propagar atualizações na ordem total faz com que essa ordem seja válida em todos os servidores.

\subsubsection{Criação e Exclusão de Réplicas}

Ao contrário de muitos sistemas distribuídos como Oracle [16], Ficus [30] e o mecanismo usado por Golding [26], que utilizam técnicas dispendiosas para criar e excluir réplicas de um grupo, Bayou adota um processo de funcionamento leve (lightweight) que lhe permite criar e excluir uma réplica comunicando-se com apenas um servidor disponível. Esse mecanismo é especialmente útil em redes de computadores móveis. Por exemplo, ao encontrar seu colega em uma viagem de negócios, um profissional pode fazer uma cópia do plano financeiro do seu colega e imediatamente começar a receber atualizações para esse plano, sem ter que esperar por uma conexão com um quórum de réplicas ou com algum servidor específico.

\section{Atualizações de Criação e de Aposentadoria}

Um servidor Bayou $S_{i}$ cria a si mesmo enviando uma atualização de criação (creation write) a um servidor $S_{j}$. Qualquer servidor pode ser usado. A atualização é tratada por $S_{j}$ como qualquer outra atualização, ou seja, ela é inserida no $\log$ de $S_{j}$ e identificada por $\left\langle C S N, T_{j, i}, S_{j}\right\rangle$, onde $T_{j, i}$ é o accept-stamp gerado por $S_{j}$.

A atualização de criação fornece um identificador globalmente único para a nova réplica e informa os demais servidores da existência de $S_{i}$ à medida que a atualização é propagada. A natureza recursiva dos identificadores dos servidores tem um grande impacto no tamanho dos vetores de versão. Por um lado, se todos os servidores forem criados a partir da primeira réplica do sistema, os identificadores dos servidores terão somente um nível de recursão e, portanto, serão pequenos. Por outro lado, se as réplicas forem criadas linearmente, os identificadores dos servidores serão progressivamente mais longos e, consequentemente, os vetores de versão terão um tamanho muito maior.

Quando uma réplica não deseja mais continuar operando, ela executa uma atualização de aposentadoria (retirement write), que é processada normalmente. Após esse 
instante, essa réplica não aceitará mais operações de clientes. No entanto, antes de se desligar, ela deve realizar pelo menos uma sessão de anti-entropia com algum outro servidor, para que suas atualizações, includindo a da sua aposentadoria, sejam propagadas para as outras réplicas. A propriedade prefixo garante que um servidor $S_{j}$ já vai ter recebido e processado todas as atualizações recebidas por $S_{i}$ antes de remover $S_{i}$ do seu vetor de versão.

\subsubsection{Políticas de Usuário}

Políticas de usuário afetam o desempenho e o custo do protocolo de anti-entropia, além de influenciarem a rapidez com a qual atualizações são propagadas e estabilizadas, o grau de consistência de uma réplica e o tamanho do log de um servidor. Bayou fornece quatro políticas de usuário:

1. Políticas para quando reconciliar dados;

2. Políticas para a escolha da réplica com a qual se quer reconciliar os dados;

3. Políticas para a exclusão de atualizações do $\log$;

4. Políticas para a escolha da réplica da qual criar um novo servidor.

Candidatos para a política de quando reconciliar dados incluem: reconciliação periódica, reconciliação desencadeada pelo usuário, reconciliação desencadeada pelo acontecimento de um evento no sistema, entre outras. Em geral, aumentar a freqüência de sessões de anti-entropia aumenta o grau de consistência entre réplicas e a rapidez com a qual atualizações são estabilizadas, a custo de um aumento no uso dos canais de comunicação.

Políticas para a escolha da réplica com a qual reconciliar dados envolvem diferentes fatores: quais réplicas podem ser contactadas e características das conexões de rede dessas réplicas, o grau de consistência das réplicas e qual é a réplica primária. Essas políticas também envolvem um compromisso entre o uso dos canais de comunicação e a rapidez de propagação das atualizações. Há técnicas eficientes para a escolha de uma réplica com a qual se deseja reconciliar os dados que permitem uma redução dramática no volume total de tráfego necessário para se propagar as atualizações, a custo de um pequeno acréscimo no tempo de propagação. Essas técnicas envolvem o favorecimento de servidores localizados nas redondezas e balanceamento de carga para evitar sobrecarregar elos de comunicação vagarosos [20,26, 64].

Políticas para exclusão de atualizações envolvem, como descrito na sessão 2.3.4, um compromisso entre o uso dos canais de comunicação e o espaço local de armazenagem do servidor. Evitar transferências do estado completo de uma réplica é importante se 
os servidores estão se comunicando por meio de uma rede com taxa de transmissão baixa e custo de acesso alto. O desafio na escolha dessa política é reduzir o espaço de armazenagem das réplicas e ao mesmo tempo minimizar a probabilidade de fazer uma transferência do banco de dados. Uma política interessante seria manter estimativas da taxa de estabilização de atualizações em cada réplica e usar esses valores para decidir quando e quantas atualizações excluir. Outra, mais simples, seria excluir atualizações quando o espaço local de armazenagem atingisse um mínimo pré-definido.

Por fim, políticas para determinar um servidor do qual criar uma nova réplica têm um grande impacto no desempenho do protocolo de anti-entropia (ver sessão 5.3). Quando vários servidores estão disponíveis, o comprimento dos seus identificadores deve ser considerado, junto com fatores como o grau de consistência da réplica, a largura de banda disponível e a completude do seu log de atualizações.

As políticas de usuário oferecidas por Bayou são um ponto chave para a flexibilidade do protocolo de anti-entropia e permitem que fatores complexos como a largura de banda disponível entre as réplicas e o custo de acesso à rede sejam tratados de maneira específica em sistemas diferentes.

\subsubsection{Suporte para Domínios Específicos de Aplicação}

Uma das caracteristicas que difere Bayou de outros sistemas de informação replicados, como Coda [45], Ficus [30], Rover [37,38] e Lotus Notes [40], é o suporte para domínios específicos de aplicação que ele oferece, que abrange cinco categorias [22]:

1. Detecção e resolução de conflitos específicos à aplicação usuária;

2. Escolha de réplicas;

3. Escolha das garantias de sessão;

4. Escolha da visão dos dados, estável ou instável;

5. Escolha das políticas de usuário.

O item 5 foi discutido na sessão 2.3.7. A seguir apresentamos uma breve discussão dos demais.

\section{Detecção e Resolução de Conflitos Específicos à Aplicação Usuária}

Os conceitos envolvidos na deteção e resolução automática de conflitos já foram discutidos na sessão 2.3.2. Essa sessão se concentra na interface necessária para a definição desses procedimentos. 
Bayou provê um mecanismo intuitivo para a definição de procedimentos de detecção e resolução de conflitos. A figura 2.3, na página 10, mostra uma atualização composta pelos procedimentos update, merge e check. Os procedimentos merge e check são opcionais e são definidos no contexto de uma atualização, ao contrário de sistemas como Coda, que exige que solucionadores de conflitos específicos (ASRs, sessão 6.2.4) sejam implementados como programas independentes e Rover, que não oferece modelos (templates) para a resolução de conflitos.

\section{Escolha de Réplicas}

Bayou permite que clientes selecionem réplicas específicas com a qual desejam realizar suas operações. Há duas vantagens principais em permitir que clientes escolham réplicas distintas ao decorrer da sua operação:

- Réplicas específicas podem ser selecionadas para otimizar esquemas de comunicação que impõem restrições. Um exemplo é um cliente que geralmente se comunica com um servidor que possui dados mais atualizados. Quando o cliente se desconecta desse servidor, ele pode executar um banco de dados no seu laptop e continuar acessando os dados. Ao se reconectar, o cliente pode mudar a sua réplica do banco de dados e voltar a acessar o servidor original;

- Aplicações de clientes distintos podem escolher uma mesma réplica e ter acesso imediato a alterações realizadas pelas outras aplicações. Desse modo, Bayou fornece suporte para que aplicações possam trabalhar de maneira altamente sincronizada.

\section{Escolha de Garantias de Sessão}

Bayou permite que aplicações usuárias acessem réplicas diferentes, com estados possivelmente divergentes. Por causa disso, operações consecutivas realizadas por clientes podem "enxergar" inconsistências no estado da informação acessada. Garantias de sessão existem para que aplicações possam estabelecer um nível de consistência mínimo para as suas próprias operações, evitando tais inconsistências.

Uma sessão é uma abstração para uma sequência de leituras (reads) e alterações (writes) realizadas pela aplicação. Garantias de sessão são implementadas restringindo o grupo de réplicas que podem ser escolhidas pelo cliente em uma sessão.

Bayou oferece quatro tipos de garantias:

- Leia suas alterações (LSA) garante que o resultado de todas as alterações realizadas anteriormente durante uma sessão são visíveis a leituras posteriores 
realizadas durante a mesma sessão. Ou seja, leituras só podem ser feitas a réplicas que contenham todas as alterações já realizadas durante essa sessão. Por exemplo, o usuário de um programa de e-mail cria um novo diretório, cujo nome é mostrado na sua tela, mas quando o cliente se comunica com uma outra réplica que não processou a criação do diretório, o nome do diretório some da tela. Com a garantia LSA, somente réplicas que já tenham processado a criação do diretório podem ser selecionadas;

- Leituras Monotônicas (LM) permite que clientes observem um banco de dados que se mantém atualizado ao decorrer do tempo. Leituras só são feitas a réplicas que possuem todas as alterações cujos efeitos foram observados por leituras anteriores durante a mesma sessão. Por exemplo, um usuário do mesmo programa de $e$-mail lê o conteúdo do seu inbox em um servidor e executa um comando para ler o conteúdo de um e-mail em particular. Sem a garantia LM, a aplicação usuária pode selecionar uma réplica que ainda não recebeu esse $e$-mail e incorretamente informar ao usuário que ele não existe. Com a garantia LM, somente réplicas que tenham processado a leitura do inbox podem ser selecionadas para processarem a leitura do e-mail;

- Alterações sucedem leituras (ASL) garante que as alterações feitas em um servidor durante uma sessão são inseridas após as alterações cujos efeitos foram observados por leituras anteriores durante a mesma sessão. Por exemplo, um usuário de um banco de dados bibliográfico lê o arquivo bibtex de um artigo e descobre que o nome de um dos autores está incorreto. O cliente realiza uma atualização corrigindo o nome do autor. A garantia ASL exige que somente uma réplica que possui a atualização de criação do arquivo possa receber a correção do cliente.

- Alterações monotônicas (AM) garante que novas alterações só são incorporadas ao banco de dados de uma réplica se todas as alterações anteriores dessa mesma sessão estiverem presentes nessa réplica e se a nova alteração for ordenada após as alterações anteriores. Um editor de textos poderia usar a garantia AM durante a edição de um arquivo replicado para garantir que a versão $n+1$ desse arquivo subsititua sua versão $n$. Em particular, a garantia MA elimina o risco da versão $n$ ser salva em um servidor qualquer, a versão $n+1$ em um servidor diferente e as duas versões serem propagadas simultaneamente, permitindo que a versão $n$ sobrescreva a versão $n+1$.

\section{Escolha da Visão dos Dados}

Bayou oferece um mecanismo que permite às aplicações usuárias diferenciarem dados estáveis de dados instáveis. Dados estáveis refletem somente a execução de atua- 
lizações estáveis, enquanto que dados instáveis correspondem a todas as atualizações processadas em uma réplica.

Bayou implementa as duas visões do banco de dados através de um vetor de bits associado a cada tupla (tuple) do banco de dados. O primeiro bit indica se a tupla faz parte da visão instável dos dados, enquanto que o segundo indica se ela faz parte da visão estável. Em um servidor que se comunica com a réplica primária freqüentemente, a visão estável do seu banco de dados é quase idêntica à sua visão instável, já que suas atualizações são estabilizadas rapidamente. Nesse caso, essa técnica reduz em metade o espaço de armazenagem do banco de dados.

\subsection{Outras Políticas de Consistência}

Uma das contribuições do sistema construído nessa dissertação é servir como arcabouço para o desenvolvimento e experimentação de políticas de consistência diversas. Nessa sessão analisaremos alguns outros mecanismos de consistência que não foram integrados ao RMIRep, mas que têm recebido atenção na literatura.

Alguns sistemas organizam seus servidores em uma hierarquia onde réplicas só podem reconciliar seus dados com seus "pais" ou "filhos". Exemplos disso são sistemas com uma arquitetura de cliente-servidor, como Coda e Rover. Bayou, por sua vez, emprega um modelo ponto-a-ponto onde qualquer par de réplicas pode trocar informação.

Todas as políticas de consistência descritas nesse capítulo são do tipo updateeverywhere. No entanto, vários mecanismos que se utilizam de uma cópia mestre (master copy) têm sido propostos. Em tais modelos, atualizações só podem ser realizadas em réplicas designadas como mestres (ou primárias). Quando uma réplica não-primária (ou escrava) deseja atualizar um objeto, ela deve mandar uma requisição à réplica primária. Atualizações realizadas na réplica mestre são propagadas para as escravas posteriormente [27,63]. Pacitti et al. [63] propõem um algoritmo que defere a propagação de atualizações realizadas em réplicas primárias por um período de tempo predefinido. Lenz [48] define o conceito de ilhas de consistência, que são grupos dinâmicos de réplicas que possuem estados altamente consistentes (de acordo com os critérios de one-copy-serializability) e que simulam a existência de uma réplica primária virtual. Dessa maneira, não há necessidade de escolher uma réplica primária física $a$ priori; a ilha de consistência pode escolher diferentes réplicas primárias ao decorrer do tempo. Réplicas que não pertencem à ilha de consistência (ou seja, que possuem consistência fraca com relação às réplicas na ilha) também podem realizar atualizações localmente, sendo posteriormente enviadas para alguma réplica na ilha, onde elas são serializadas em todos os seus componentes. Dessa maneira, a ilha de consistência funciona como uma réplica primária virtual para réplicas fora da ilha. 
Gray et al. [27] propõem um modelo de duas camadas (two-tier), onde há dois tipos de réplicas: móveis e fixas. Réplicas fixas estão sempre conectadas e mantém seus estados completamente sincronizados entre si. Réplicas móveis estão quase sempre desconectadas e devem reconciliar seus dados com alguma réplica fixa quando forem reconectadas. Nesse esquema, cada objeto (unidade de informação) possui uma casa, que é responsável por estabilizar atualizações realizadas a esse objeto. Um objeto replicado que não reside na sua casa é denominado instável, enquanto que objetos que moram em suas casas são chamados de estáveis. A maioria dos objetos nesse modelo reside em réplicas fixas, embora as móveis possam hospedar um número bem menor deles. Quando uma réplica está desconectada, atualizações realizadas em objetos estáveis são estabilizadas imediatamente, enquanto que as realizadas em objetos instáveis precisam ser validadas junto à casa do objeto alterado, uma vez que a réplica se reconectar. Esse mecanismo não provê suporte para a resolução automática de atualizações conflitantes. Ao invés disso, espera-se que as atualizações sejam projetadas para serem comutativas entre si.

A política de consistência total descrita nesse capítulo faz parte da família de protocolos ROWA [6] (Read-One-Write-All), onde uma atualização submetida lê o estado de uma só réplica (geralmente a mesma onde a atualização foi submetida) e altera o estado de todas. Duas outras políticas ROWA são (1) o mecanismo de callback, utilizado por Coda para informar seus clientes a respeito de atualizações realizadas nos seus servidores e (2) a técnica de invalidação, tradicionalmente usada para manter a consistência de caches em modelos de memória distribuída compartilhada (Distributed Shared $\mathrm{Me}$ mory, DSM $[13,82])$, mas que também têm sido empregadas para manter a consistência de objetos replicados em computadores móveis. No mecanismo de callback de Coda, um cliente registra um procedimento callback no servidor ao obter uma réplica de um objeto. Daí em diante, alterações realizadas no estado desse objeto no servidor ou em outro cliente são propagadas aos demais clientes por meio dos procedimentos callbacks. O mecanismo de invalidação, por outro lado, não tenta manter cópias sincronizadas em várias réplicas: alterações feitas na cópia matriz de um objeto invalidam o estado das suas réplicas localizadas em servidores remotos. A cópia (ou réplica) matriz é o único objeto do qual réplicas podem ser feitas e é responsável por manter a consistência do objeto. Há duas maneiras de invalidar réplicas. Na primeira, clientes que possuem cópias de um objeto podem apurar (poll) o estado da réplica matriz periodicamente. No entanto, em ambientes de computadores móveis, onde a latência das operações é grande devido a conexões sem fio, o modelo pull [70] que essa técnica usa geralmente produz sobrecargas de tempo inaceitáveis. A segunda técnica é baseada no modelo push [70], onde a cópia matriz envia mensagens de invalidação a todas as suas réplicas quando o seu estado é alterado. A desvantagem desse mecanismo, quando usado em ambientes móveis, é que os clientes passam a maior parte do tempo desconectados e portanto não podem receber a maioria das mensagens de invalidação. Jing et al. [35] propõem um algoritmo baseado no modelo push que ajusta o tamanho das mensagens 
de invalidação (invalidation reports) enviadas às réplicas de um objeto dinamicamente. Esse algoritmo visa ambientes de computadores móveis onde os objetos que serão replicados são conhecidos a priori e utiliza um vetor de bits que especifica, para uma janela de tempo $w$, os objetos que foram alterados durante essa janela e que por isso devem ser invalidados. Esse algoritmo também fornece suporte à replicação de objetos em um grupo dinâmico de servidores em ambientes onde esses servidores estão continuamente conectados.

Outro mecanismo de consistência tradicionalmente usado em DSMs é Lazy Release Consistency (LRC) [43,82], que se baseia na observação de que, em muitos casos, ações de consistência não são necessárias até certos pontos de sincronização serem alcançados. Ionitoiu et al. [33] propõem um modelo de replicação de objetos com consistência relaxada que usa LRC para propagar atualizações feitas em uma réplica quando isso for necessário (on demand). O projeto do modelo proposto por Ionitoiu não parece fornecer suporte para computadores móveis. 


\section{Capítulo 3}

\section{O Sistema Java RMI}

Sistemas distribuídos requerem que objetos residentes em espaços de memória distintos, possivelmente em máquinas diferentes, se comuniquem. O modelo de chamada remota de procedimentos (remote procedure call, RPC [60]) tem se tornado um dos mecanismos de comunicação mais populares desde que foi inicialmente proposto por Birrel e Nelson em 1984 [10]. RPC é uma abstração expressa em nível de linguagem de alto nível que se baseia no paradigma de requisição e resposta (request-reply) e permite que entidades residentes em espaço de memória distintos se comuniquem por meio do mecanismo de chamada de procedimentos.

Nos últimos anos, a popularização do modelo de programação orientado a objetos tem ocasionado o desenvolvimento de vários sistemas que se baseiam nos conceitos de RPC para permitir que objetos residentes em espaços de memória distintos se comuniquem por meio da invocação remota de métodos (Remote Method Invocation, RMI). Dois desses sistemas são o Common Object Request Broker Architecture (CORBA [28]), desenvolvido pelo Object Management Group e o Distributed Common Object Model (DCOM [55]) da Microsoft.

O sistema Java Remote Method Invocation (Java RMI $[57,76,78]$ ) é um modelo de objetos distribuídos que incorpora muitos dos conceitos presentes em sistemas de RPC anteriores e permite que um objeto em uma máquina virtual Java (JVM [49]) invoque métodos de um outro objeto residente em uma JVM distinta. Java RMI, no entanto, oferece características não presentes em sistemas de RPC anteriores, como a coleta de lixo distribuída e polimorfismo [58].

Como muitas das idéias de Java RMI são baseadas em RPC, a seguir descreveremos os conceitos básicos desse mecanismo. 


\subsection{Chamada Remota de Procedimento}

A operação que chama um procedimento tradicional e espera por seu resultado é similar ao processo de comunicação que envolve uma operação de requisição e resposta. Essa semelhança foi a motivação principal para o desenvolvimento de RPC. Em uma chamada remota de procedimento, o processo que executa o procedimento (denominado requisitante) bloqueia ${ }^{1}$ e transfere os argumentos (possivelmente envolvendo a rede) para o ambiente onde o procedimento será executado (denominado receptor). O resultado é enviado de volta ao requisitante, de maneira análoga ao retorno do resultado de um procedimento tradicional. Há várias vantagens relacionadas ao uso de chamadas remotas de procedimentos:

- Transparência: não há diferença na sintaxe de procedimentos locais e remotos e portanto a localização do servidor onde a implementação do procedimento se encontra é irrelevante para a aplicação usuária. Além disso, detalhes do protocolo de comunicação, como a conversão de parâmetros, são escondidos da aplicação usuária. Por outro lado, a semântica de RPC difere quanto a de procedimentos locais, já que a execução remota de um procedimento pode envolver comunicação através de uma rede. Por causa disso, mecanismos de RPC devem lidar com questões como erros de transmissão e falhas no protocolo de comunicação;

- Generalidade: em linguagens procedimentais, procedimentos são o mecanismo de comunicação mais eficiente que existe entre partes de um algoritmo;

- Simplicidade: a semântica do mecanismo de chamadas de procedimentos é bem compreendida. Ao associar o modelo de comunicação a esse mecanismo, economiza-se o tempo que seria gasto para que profissionais pudessem aprender e adquirir experiência com um outro mecanismo.

\subsubsection{Estrutura do RPC}

A estrutura de um programa que usa RPC é baseada no conceito do stub, que funciona como um agente procurador (proxy) no cliente. Um procurador age como o representante de uma entidade que não está fisicamente presente em um certo local. Nesse caso, a entidade ausente é o código do procedimento. A realização de um procedimento remoto envolve cinco componentes: o usuário, também chamado de cliente, o $s t u b$ do cliente, o ambiente de execução do RPC, o servidor (o processo que implementa o procedimento remoto) e o stub do servidor, posteriormente chamado de esqueleto. A figura 3.1 mostra a relação entre esses objetos. Uma chamada remota é iniciada por

\footnotetext{
${ }^{1}$ Desde então, alguns modelos de RPC assíncronos têm sido propostos $[14,50]$.
} 


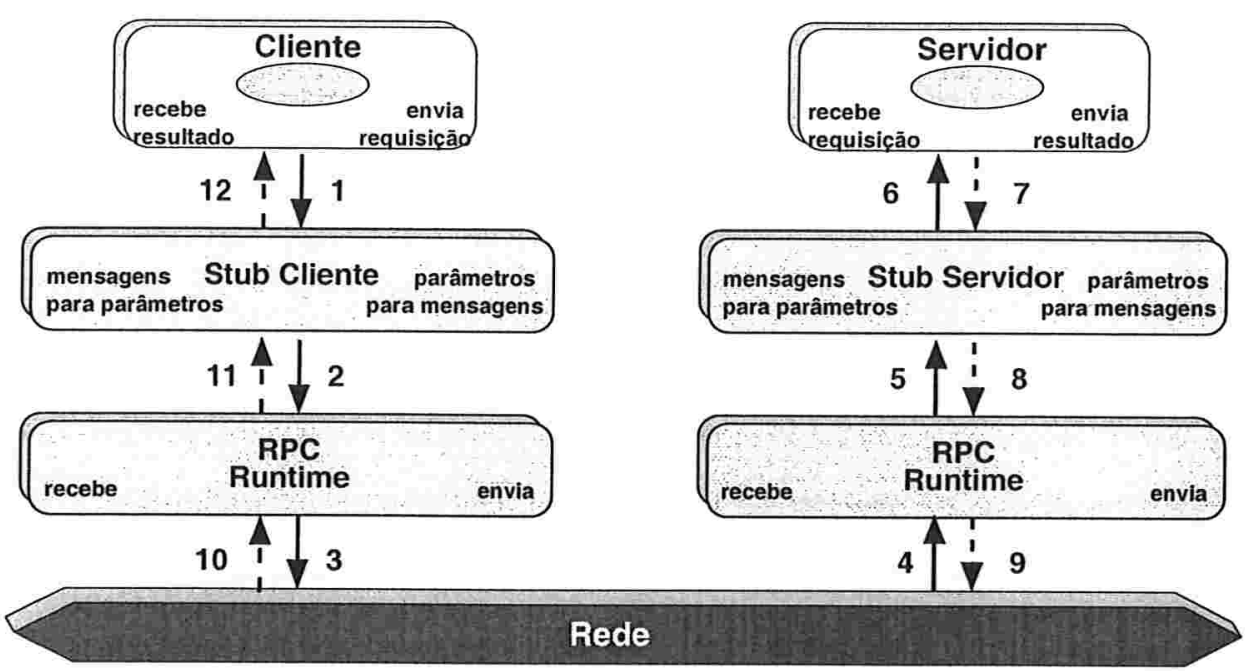

Figura 3.1: Componentes da arquitetura de RPC

um cliente, que realiza uma chamada local normal, que por sua vez invoca o procedimento correspodente no stub. O stub é responsável por empacotar os argumentos para o ambiente de execução do RPC (parameter marshaling). Além disso, ele deve enviar um identificador do procedimento chamado para que $s t u b$ do servidor possa direcionar a chamada para o procedimento correto. O ambiente de execução do RPC transmite os argumentos à camada de transporte, geralmente por meio de soquetes [68] (sockets). Ao receber um sinal da camada de transporte, o ambiente de execução do RPC no servidor intercepta a chamada remota e a passa para o stub do servidor, que desempacota os argumentos (parameter unmarshaling) e executa o procedimento. Ao terminar, os resultados são empacotados e retornados passando pelo stub do servidor, ambiente de execução do RPC no servidor e no cliente e finalmente pelo $s t u b$, que retorna o resultado ao cliente depois de desempacotá-lo. Além de questões que dizem respeito a falhas e ao processo de associação (binding) entre o cliente e o servidor, a chamada remota acontece da mesma maneira que um procedimento local.

\subsubsection{Transmissão de Parâmetros e Conversão de Dados}

As regras de RPC que dizem respeito à transmissão e à conversão de dados são responsabilidade do stub. Várias semânticas de transmissão de parâmetros existem, dentre as quais as mais populares são:

- Call-by-value: os argumentos passados ao procedimento são copiados em estruturas de dados auxiliares. Modificações feitas pelo servidor nessas cópias não são visíveis ao cliente quando a chamada retorna. Essa semântica é fácil de ser implementada no RPC; 
- Call-by-copy-restore: os argumentos passados ao procedimento são copiados em estruturas de dados auxiliares de modo análogo à semântica call-by-value. No entanto, quando o procedimento termina, os parâmetros são copiados e retransmitidos ao cliente. Dessa maneira, modificações realizadas pelo servidor são visíveis ao cliente.

Parâmetros simples (int, boolean, etc.) podem ser passados facilmente por RPC, enquanto que estruturas mais complexas, como árvores e grafos, impõem grande sobrecarga ao mecanismo de transmissão.

Um outro problema diz respeito às regras quanto à transmissão de mensagens pela rede, por causa da possível heterogenidade entre os modelos de representação de dados do cliente e do servidor. Algumas linguagens de alto-nível representam dados de maneira distinta (um int, por exemplo, pode ser representado usando 2 ou 4 bytes). Além disso, sistemas diferem quanto à posição do bit mais signicativo de uma mensagem: algums sistemas usam a ordem big-endian, com o bit mais significativo primeiro. Outros utilizam a ordem little-endian, com o bit menos significativo primeiro. Essas questões, entre outras [15], podem ser resolvidas através da utilização de uma linguagem canônica, usada para representar os dados de maneira neutra. Embora permitam que processos com maquinários heterogêneos se comuniquem de maneira simples, linguagens canônicas impõem sobrecargas aos processos, que devem traduzir suas representações nativas para a representação canônica em cada chamada remota. Por fim, linguagens canônicas podem ser usadas para a especificação de interfaces independentes de linguagens de programação específicas. Exemplos de linguagens canônicas são a XDR [73] e a IDL [62].

\subsubsection{Geração de Stubs}

A compilação de programas que utilizam RPC requer a especificação de uma interface (interface module) com o nome de todos os procedimentos que podem ser chamados por processos remotos, junto com os tipos e as semânticas dos parâmetros e o tipo do resultado de cada procedimento. A especificação de interface é suficiente para que o cliente e o servidor possam compilar seus programas independentemente. O stub do cliente gerado contém código para que um cliente possa se associar (bind) a um servidor e o stub do servidor gerado possui funcionalidade para permitir que um servidor seja registrado (como explicado a seguir).

A principal vantagem do uso de stubs é isolar o usuário do código relacionado com a comunicação entre processos. Após escrever a especificação de interface, o programador só precisa implementar o código do servidor e do cliente: o sistema RPC é responsável por lidar com os aspectos de baixo-nível que dizem respeito à comunicação. 


\subsubsection{Associação (Binding)}

Os mecanismos de associação entre um cliente e um servidor devem satisfazer duas questões principais:

- Naming: como um cliente especifica o servidor ao qual ele quer se associar?

- Localização: como um cliente especifica o endereço da máquina onde o servidor está executando?

Um programa que implementa a especificação de uma interface exporta essa interface (exportador) e um programa que chama os procedimentos definidos em uma especificação de interface a importa (importador). O mecanismo de associação deve ligar um importador a um exportador de uma mesma interface. Após essa associação, chamadas feitas pelo importador invocam procedimentos implementados no exportador.

O mecanismo de associação envolve quatro etapas:

1. Quando um servidor deseja tornar uma interface disponível remotamente, ele envia a sua localização a um serviço de nomes com endereço fixo. A sua localização consiste do endereço da máquina onde ele está executando (globalmente único), da porta onde o servidor aceitará invocações remotas e de um identificador (único no contexto da máquina onde o servidor está executando), que serve para localizar o processo do servidor. Outras alternativas para o serviço de nomes com endereço fixo têm sido exploradas. O projeto inicial de Birrel e Nelson, por exemplo, utilizou o banco de dados replicado Grapevine [9] para armazenar referências para interfaces exportadas. $\mathrm{O}$ uso de um banco de dados replicado (ou de um serviço de nomes replicado, ver sessão 3.3.2) fornece maior disponibilidade de acesso aos clientes;

2. Antes de realizar um procedimento, o cliente requisita ao serviço de nomes um gancho (handle) para o exportador da interface desejada;

3. O serviço de nomes retorna ao cliente o endereço, a porta e o identificador do servidor que implementa a interface desejada;

4. O ambiente de execução do RPC constrói uma referência para o cliente, que é usada para toda chamada remota futura. Cada requisição enviada pelo cliente inclui o endereço, a porta e o identificador obtidos do serviço de nomes. 


\subsubsection{Extensões do RPC}

Várias extensões têm sido propostas ao mecanismo básico de RPC. Lightweight RPC (LRPC [8]), por exemplo, explora a semântica de chamadas de procedimento que envolvem domínios de proteção diferentes em uma mesma máquina. LRPC sacrifica muito da generalidade de RPC em troca de um desempenho maior no caso médio.

O mecanismo tradicional do RPC possibilita a comunicação de um cliente com apenas um servidor. Técnicas de comunicação de grupo, aliadas aos conceitos de sistemas $\mathrm{RPC}$ tradicionais, permitem a um conjunto de réplicas se comunicarem eficientemente, através de procedimentos remotos. O ambiente de execução do RPC envia requisições a todos os participantes do grupo transparentemente, isentando o cliente de executar um procedimento para cada membro do grupo separadamente. Uma outra extensão de RPC diz respeito a falhas em sistemas distribuídos, que podem produzir consequências indesejáveis na execução de um procedimento remoto. Em particular, clientes que requisitam a execução remota de um procedimento em um servidor e depois falham produzem computações órfãs, que consomem recursos no servidor, incluindo tempo de CPU, locks e espaço de armazenamento. Um exemplo de um sistema que estende RPC para dar suporte a comunicação de grupo, detecção de falhas e tratamento de computações órfãs é o projeto FITOS [3].

\subsection{O Sistema Java RMI}

Java RMI é um sistema de invocação remota de métodos que estende os conceitos de RPC para dar suporte a objetos distribuídos Java. Há várias diferenças entre sistemas de RPC mais tradicionais, como o CORBA e o DCOM e o Java RMI. Essas diferenças resultam dos ambientes de operação distintos para os quais esses modelos foram construídos. A seguir examinaremos essas diferenças.

Mecanismos de RPC tradicionais, dos quais DCOM e CORBA fazem parte, foram construídos tendo em mente a heterogeneidade dos componentes de rede e de hardware de diferentes processos. Como descrito na sessão 3.1.2, o sistema distribuído em uso pode conter máquinas diferentes, com sistemas operacionais e representações de dados distintos. A solução encontrada para que esses componentes pudessem se comunicar foi o desenvolvimento de procuradores (stubs e esqueletos) que convertem dados enviados por outras máquinas. Linguagens para a definição de interfaces de procedimentos remotos, tal como a IDL [62], foram desenvolvidas para lidar com representações de dados diferentes. Há duas desvantagens principais relacionadas ao uso de IDLs:

- A natureza neutra de uma IDL restringe a classe de parâmetros que podem ser passados em um procedimento remoto a tipos básicos (como int) e a objetos remotos. Essa restrição vem do fato de que os parâmetros definidos em IDL devem 
possuir uma representação equivalente na linguagem de programação usada pelo cliente/servidor;

- A natureza dos dados passados em procedimentos remotos é estática. O receptor de uma chamada remota precisa saber exatamente o tipo do objeto que está sendo transmitido pela rede, para que ele possa associar o stub/esqueleto correspondente ao objeto transmitido. Portanto, o uso de polimorfismo [58] não é permitido a classe de um objeto transmitido não pode ser uma subclasse (mais específica) da classe esperada. Caso isso aconteça, o receptor converte o objeto transmitido (implicit casting) ao tipo esperado por ele (menos específico), introduzindo a possibilidade de erros no programa.

Java RMI, por sua vez, não precisa lidar com questões relacionadas com heterogenidade, já que tanto as classes do cliente como do servidor são escritas em Java e executam em JVMs, o que torna a rede uma coleção de máquinas (virtuais) homogêneas e elimina a necessidade de linguagens adicionais como a IDL.

A principal característica que distingue Java RMI de outros sistemas RPC, no entanto, é a sua capacidade de carregar o código fonte de classes remotas dinamicamente, permitindo o uso de polimorfismo. O mecanismo que realiza essa operação é composto por três componentes principais: um carregador de classes especializado, um gerenciador de segurança e a técnica de conserva (pickling [69]). A técnica de conserva permite que um objeto seja representado como um sequência de bytes e inclui informação sobre o tipo de objeto e sobre a localização do seu código fonte. Quando uma JVM recebe a referência de um objeto remoto, ela verifica o tipo específico do objeto. Se a JVM não possuir o stub específico para esse objeto, o carregador de classes especializado pode localizar e carregar o seu código fonte utilizando o endereço que o objeto carrega consigo. O código é verificado pelo gerenciador de segurança antes de ser executado. Uma descrição mais detalhada sobre o mecanismo usado por Java para carregar código dinamicamente encontra-se em [78].

A figura 3.2 exemplifica uma interação típica entre um cliente e um servidor Java RMI. O servidor (1) registra uma referência para um objeto remoto no serviço de nomes e (2) após obter essa referência, (3) o cliente pode executar chamadas diretamente nesse objeto, possivelmente obtendo referências para outros objetos remotos. A figura também mostra um servidor de web sendo usado para transferir o código e o estado dos objetos que são passados em invocações remotas.

\subsubsection{Modelo de Sistema Básico}

Com exceção das características discutidas na sessão anterior, o modelo de sistema de Java RMI é bastante similar ao de outros mecanismos de RPC mais tradicionais. A seguir apresentamos esse modelo. 


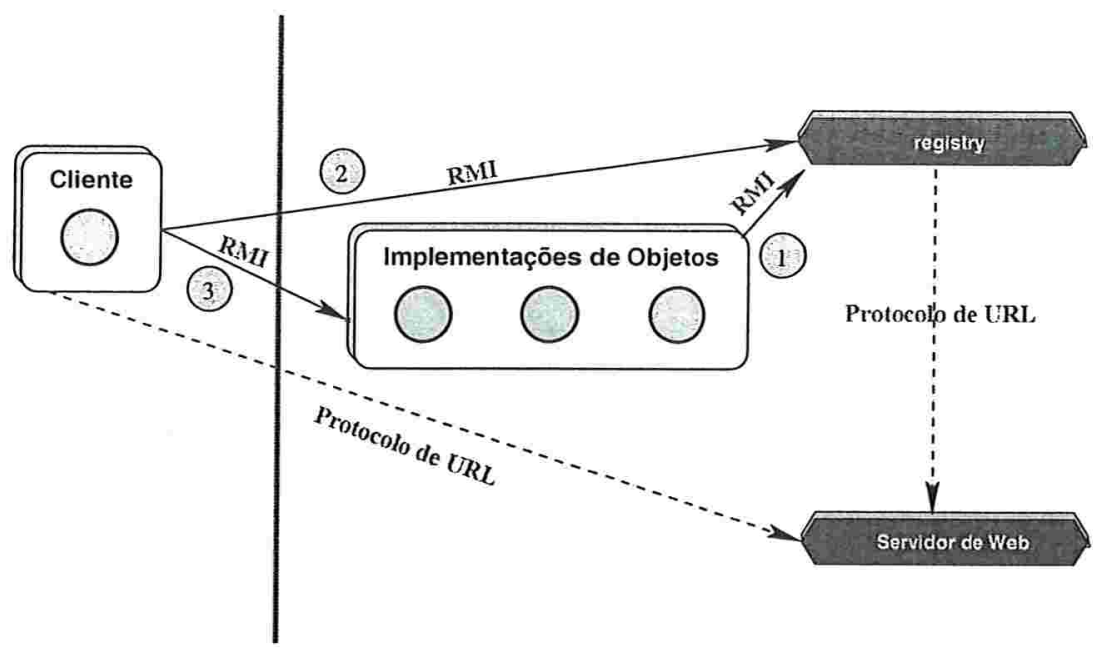

Figura 3.2: Exemplo de uma interação típica entre um cliente e servidor RMI [12]

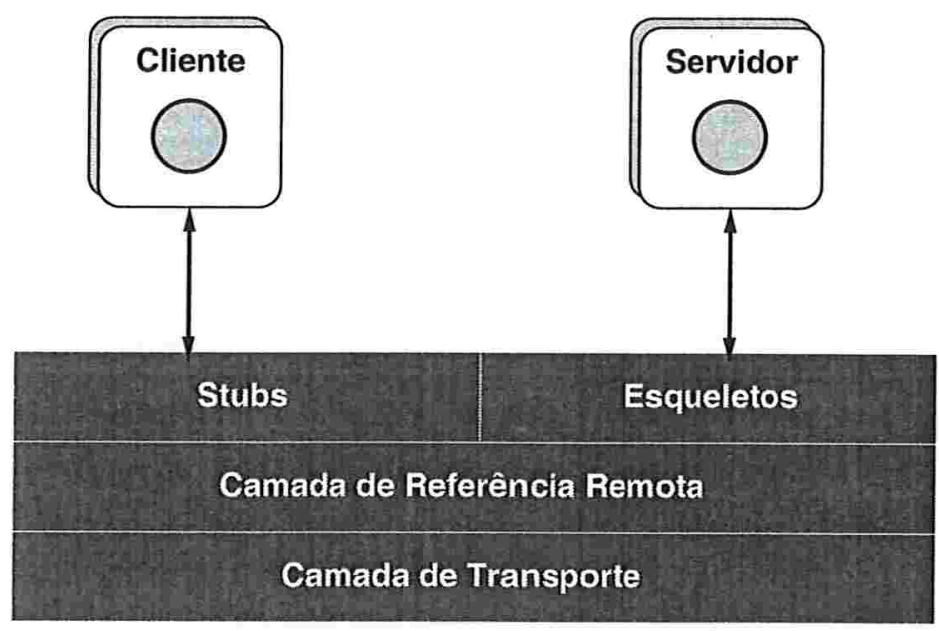

Figura 3.3: Arquitetura de alto-nível do RMI [78]

A funcionalidade básica do sistema Java RMI se encontra nos pacotes java.rmi, java.rmi.server, sun.rmi.server e sun.rmi.transport. As classes contidas no pacote sun são específicas à implementação do JDK (Java Development Kit) da Sun.

No modelo do Java RMI, um objeto é denominado remoto se os seus métodos podem ser invocados por objetos residentes em um espaço de memória distinto. Uma interface remota deve ser derivada, direta ou indiretamente, da interface java.rmi.Remote. Métodos definidos em interfaces remotas são denominados remotos e devem incluir a exceção java.rmi.RemoteException na sua cláusula throws. Uma exceção RemoteException é criada quando, durante uma invocação remota, alguma falha de co- 
municação ocorre. Somente métodos remotos estão disponíveis remotamente. Além deles, um objeto remoto pode definir outros métodos não-remotos, que só serão acessíveis localmente.

A arquitetura de Java RMI consiste de três camadas, como mostra a figura 3.3: a camada de stub/esqueleto, a camada de referência remota e a camada de transporte. O servidor que estiver exportando interfaces remotas pode estender java.rmi.server. UnicastRemoteObject ${ }^{2}$, que define a funcionalidade básica para um objeto remoto (como explicado a seguir).

Stubs e esqueletos são gerados pelo script rmic, que recebe como entrada o arquivo .class correspondente à implementação do servidor.

Quando um servidor é criado, o construtor de UnicastRemoteObject executa o método exportobject, que instancia e exporta um objeto sun.rmi.server.UnicastServerRef. Ele também cria uma referência viva (live reference), que representa a camada de transporte do servidor e contém um endereço IP, uma porta TCP e um identificador do objeto. Além disso, exportobject instancia o stub e o esqueleto do objeto. Depois disso, uma associação entre o identificador do objeto e o stub/esqueleto é registrado em uma tabela de objetos, residente na camada de transporte.

O cliente, por sua vez, obtém uma referência a um objeto remoto por meio do serviço de nomes rmiregistry ou através de outros objetos remotos. O stub funciona como uma camada entre o cliente e as outras camadas do Java RMI e a sua principal função é o empacotamento (marshaling) e desempacotamento (unmarshaling) de parâmetros enviados e recebidos de invocações remotas. O stub contém um objeto java.rmi.server.RemoteRef, que encapsula a camada de transporte do cliente e que obtém a referência viva do servidor quando uma invocação remota é realizada, estabelecendo uma conexão com ele. O stub chama o método invoke de RemoteRef para realizar a invocação remotamente. Quando a chamada chega ao servidor, a camada de transporte usa a sua tabela de objetos junto com o identificador da invocação para obter o esqueleto do objeto remoto ${ }^{3}$. O esqueleto desempacota os argumentos, realiza uma chamada à implementação do objeto e retorna o resultado ao cliente. Java RMI possui maquinário suficiente para diferenciar o resultado normal de uma invocação de uma exceção. A figura 3.4 mostra as fases de uma invocação típica feita por um cliente a um objeto remoto.

Qualquer objeto Java pode ser passado como argumento ou retornado como resultado de uma chamada remota. Java RMI implementa a semântica de transmissão

\footnotetext{
${ }^{2}$ Caso esse objeto não estenda UnicastRemoteObject, ele deve definir funcionalidade equivalente à que esse objeto implementa.

${ }^{3}$ A partir da versão 1.2 .2 do JDK, Java RMI não utiliza esqueletos. A camada de referência do lado do servidor possui maquinário suficiente para desempacotar argumentos e fazer uma chamada diretamente à implementação do objeto.
} 


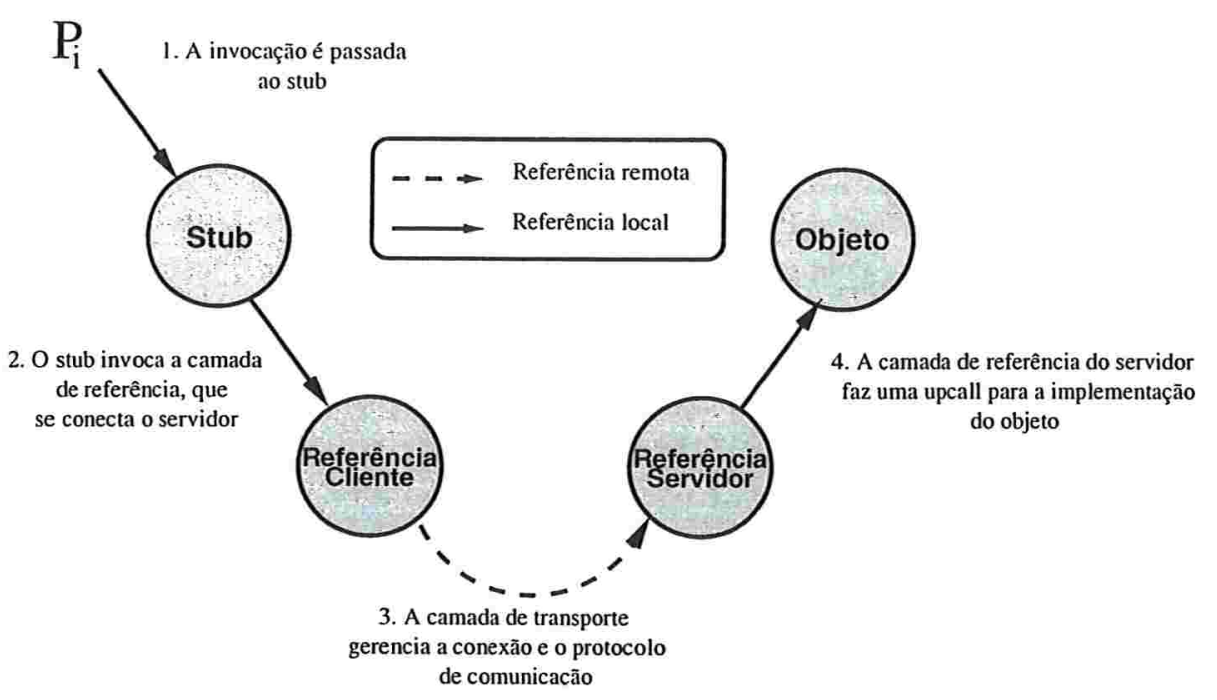

Figura 3.4: Uma invocação típica a um objeto remoto

call-by-value para objetos não-remotos.

\subsubsection{Coleta de Lixo Distribuída}

Uma outra característica que distingue Java RMI de outros mecanismos de RPC tradicionais é o seu mecanismo distribuído de coleta de lixo. Técnicas de gerenciamento de dados distribuídos, como a contagem explícita de referências, geralmente são complicadas e por isso têm um grande potencial para introduzir falhas no sistema [76]. Java RMI fornece suporte transparente para a coleta de lixo em aplicações distribuídas através de um protocolo que utiliza a contagem de referências. $\mathrm{O}$ ambiente de execução do Java RMI mantém uma tabela que contém, para cada objeto remoto, o número de referências locais para esse objeto. Quando a referência de um objeto remoto é instanciada pela primeira vez em uma JVM, Java RMI invoca o método referenced desse objeto e cria uma entrada para ele em sua tabela. Essa entrada contém um contador do número de processos locais que contém referências a esse objeto. À medida que clientes deixam de usar uma referência, o contador do objeto remoto decresce e, ao chegar em zero, Java RMI invoca o método unreferenced desse objeto. Quando nenhuma máquina virtual possui referências para um servidor e o mecanismo de coleta de lixo local dessa máquina indica que não há processos locais que possuem uma referência para ele, o servidor é coletado. Esse protocolo não funciona corretamente na presença de falhas. Especificamente, se uma partição na rede separar o cliente de um servidor, é possível que o servidor seja coletado prematuramente. 


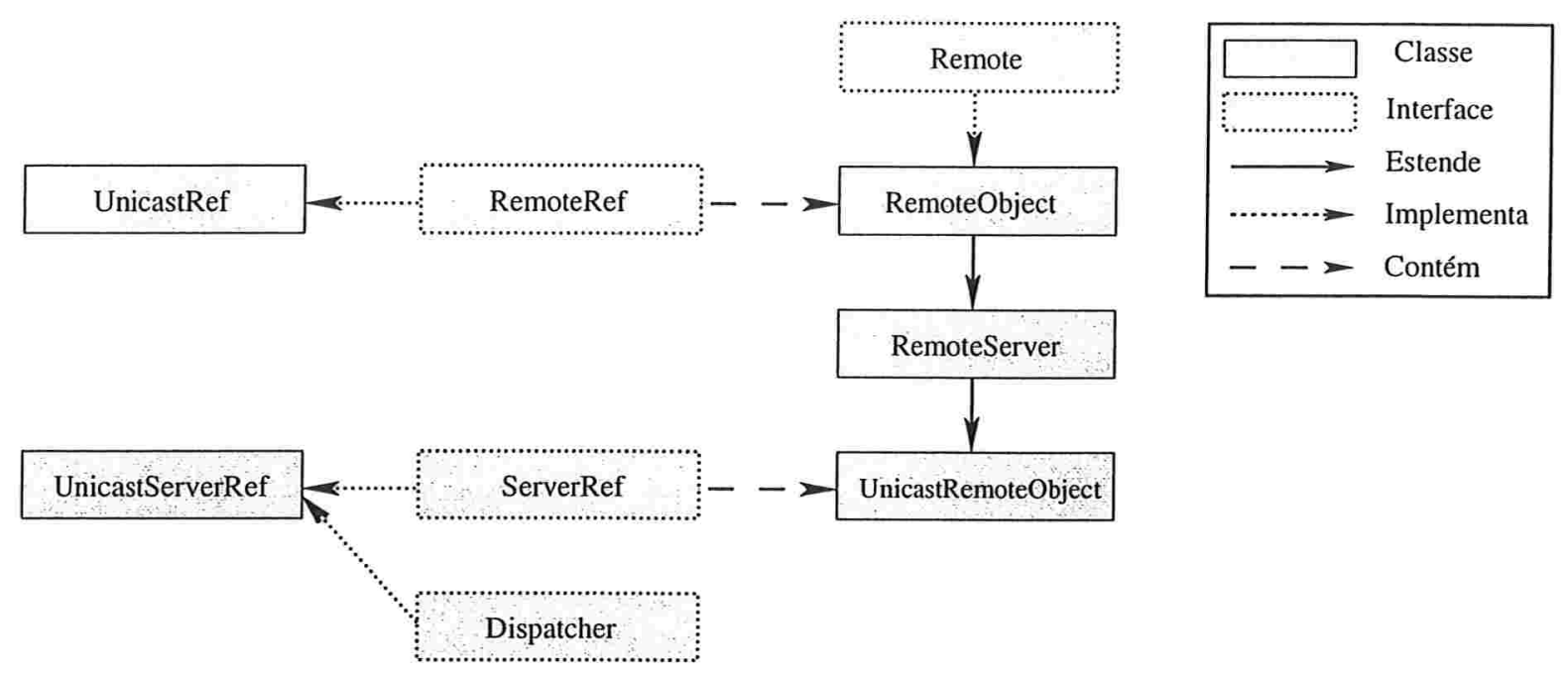

Figura 3.5: Hierarquia parcial de classes do RMI

\subsubsection{A Hierarquia de Classes}

A figura 3.5 apresenta a hierarquia das classes e interfaces do RMI relevantes ao nosso projeto. A seguir damos uma breve explicação de cada uma delas. As classes UnicastRef e UnicastServerRef e as interfaces RemoteRef e ServerRef representam a camada de referência remota da arquitetura do Java RMI (figura 3.3).

\section{Interface java.rmi.Remote}

Remote serve para identificar interfaces cujos métodos podem ser chamados de uma JVM remota. Toda interface remota deve estender, direta ou indiretamente, essa interface. Somente os métodos de um objeto especificados por uma interface remota estão disponíveis remotamente. Cada método de uma interface remota deve incluir a exceção RemoteException em sua cláusula throws.

Interface java.rmi.server.RemoteRef

Essa interface representa o gancho para um objeto remoto. O seu método mais importante é invoke, que permite a um stub invocar um método de um objeto remoto. RemoteRef contém uma referência viva (sun.rmi.transport. LiveRef), que representa a camada de transporte do sistema Java RMI. 
Interface java.rmi.server.ServerRef

Essa interface estende RemoteRef e adiciona métodos para permitir que um objeto remoto possa ser exportado. Ao ser exportado, um objeto disponibiliza o endereço da máquina onde ele está executando, a porta onde ele receberá invocações remotas, o seu identificador e um objeto Dispatcher, como explicado a seguir. A camada de transporte armazena essas informações em uma tabela de objetos para que quando uma invocação chegue, ela possa ser direcionada ao esqueleto correto.

Interface sun.rmi.server.Dispatcher

Essa interface define um método, dispatch, que é responsável por delegar uma invocação remota interceptada pela camada de transporte de um servidor para a implementação de um objeto remoto. Quando um objeto é exportado, ele passa à camada de transporte um objeto Dispatcher, que é armazenado em uma tabela de objetos. Quando uma invocação remota chega ao servidor, a camada de transporte utiliza essa tabela para identificar o objeto Dispatcher ao qual a invocação deve ser encaminhada e invoca o método dispatch desse objeto, que identifica o método do objeto remoto a ser invocado.

Classe java.rmi.server.RemoteObject

Essa classe implementa a funcionalidade de java.lang.Object no contexto de objetos remotos. Especificamente, RemoteObject sobrescreve os métodos equals, hashCode, toString e clone. A seguir analisamos as semânticas desses métodos em objetos remotos:

- equals: enquanto que o método Object.equals implementa a semântica de igualdade de conteúdo (ou seja, dois objetos são iguais se possuem o mesmo estado interno), o método RemoteObject. equals implementa a semântica de igualdade referencial: dois objetos remotos são iguais se as suas referências remotas são iguais, ou seja, se eles se referem à mesma implementação de um mesmo objeto. Implementar a semântica de igualdade de conteúdo em objetos remotos requeriria chamadas remotas para comparar os estados de dois objetos, aumentando consideravelmente a latência de uma invocação típica a equals. Além disso, chamadas remotas podem ocasionar a exceção RemoteException, que o método Object.equals não inclui na sua cláusula throws. Portanto, somente a semântica de igualdade referencial pode ser implementada em Java RMI sem custos adicionais; 
- hashCode: retorna o mesmo valor para dois objetos que possuem a mesma referência remota;

- toString: retorna um objeto String que representa a referência desse objeto. $\mathrm{Na}$ implementação atual do JDK, que suporta somente objetos não-replicados, o resultado desse método contém informação sobre o endereço, a porta e um identificador do objeto remoto;

- clone: fazer o clone de um objeto remoto é uma operação local e não pode ser usada por clientes para criar novos objetos remotos. Essa operação, quando realizada em clientes, cria uma nova referência para o mesmo objeto remoto, mas não efetua a cópia de nenhuma das suas estruturas internas, já que isso envolveria chamadas remotas e poderia gerar uma possível exceção RemoteException, que object.clone não inclui na sua cláusula throws.

\section{Classe java.rmi.server.RemoteServer}

RemoteServer é a superclasse comum a todas as implementações de servidores e oferece um arcabouço para uma grande variedade de referências remotas. Especificamente, RemoteServer define métodos abstratos para que um objeto remoto possa ser exportado. Atualmente, o Java RMI só implementa referências remotas não-replicadas (unicast), que podem ser transientes ou persistentes. Referências transientes são representadas pela classe UnicastRemoteObject e são válidas somente enquanto o servidor estiver executando. Referências persitentes são representadas pela classe Activatable e podem ser ativadas automaticamente.

Classe java.rmi.server.UnicastRemoteObject

Essa classe define um objeto não-replicado (unicast), cujas referências são válidas somente enquanto o processo servidor estiver executando. A principal funcionalidade que UnicastRemoteObject oferece é a exportação de objetos remotos.

Um objeto remoto não derivado de UnicastRemoteObject deve ser capaz de exportar a si mesmo e deve implementar toda a funcionalidade definida por RemoteServer.

\section{Classe sun.rmi.server.UnicastRef}

Essa classe é a referência remota de um cliente e implementa a interface RemoteRef. Ela disponibiliza o método invoke, que realiza uma invocação remota a um objeto. UnicastRef representa a camada de referência de um objeto remoto não-replicado, cujo estado não pode ser replicado em nenhuma JVM remota. 
Classe sun.rmi.server. UnicastServerRef

Essa classe é a referência remota de um servidor e implementa as interfaces ServerRef e Dispatcher. Ela disponibiliza métodos para exportar um objeto remoto e para despachar uma invocação remota enviada por um cliente de uma JVM remota à implementação do objeto.

\subsection{Contextualização do Java RMI na Literatura}

A popularização do sistema Java RMI tem levado pesquisadores a utilizá-lo como base para a construção de sistemas mais complexos, que fornecem funcionalidade específica para alguns tipos de aplicações.

Nessa sessão apresentaremos brevemente o projeto dos sistemas Manta e Filterfresh, com ênfase em como esses sistemas utilizam idéias presentes no sistema Java RMI para atingir seus objetivos.

Nos últimos anos, tem havido grande interesse no uso de Java em aplicações de computação paralela de alto desempenho. O seu modelo de programação seguro (type-safe) e orientado a objeto, junto com o suporte para concorrência que ela oferece, tornam Java uma ótima candidata para o desenvolvimento de aplicações paralelas de grande porte [53]. No entanto, embora Java ofereça mecanismos eficientes para a programação de sistemas baseados em múltiplos processadores compartilhados (SMPs), por meio do seu pacote de threads, ela não fornece suporte adequado para o desenvolvimento de aplicações paralelas em máquinas com memórias distribuídas [66]. O sistema Manta foi projetado para dar suporte a essas aplicações.

Um problema ortogonal diz respeito à disponibilidade de dados armazenados em servidores e o custo de acesso a esses dados. A atual implementação de Java RMI não fornece suporte para servidores tolerantes a falhas. Aplicações que estejam interessadas em detectar e resolver falhas nos componentes de uma computação distribuída devem implementar essa funcionalidade no nível da aplicação. Filterfresh é um pacote que dá suporte para a construção de servidores tolerantes a falhas.

\subsubsection{Manta}

O JDK da Sun é um sistema Java baseado em compilação just-in-time (JIT [79]), que gera código nativo à plataforma onde a JVM está executando imediatamente antes de um método ser executado. Compiladores JIT produzem código nativo para cada método por vez, à medida que eles são invocados.

O sistema Manta $[53,54]$, desenvolvido na Universidade Vrije, na Holanda, é um 


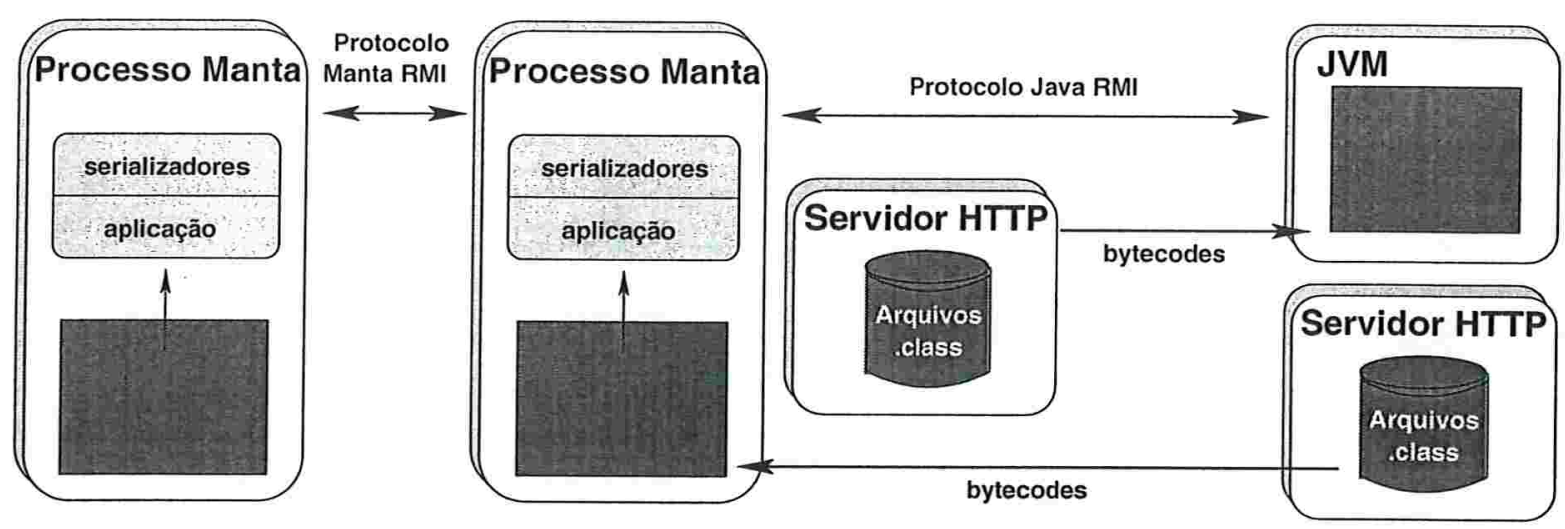

Figura 3.6: Interoperabilidade entre Manta e uma JVM

sistema Java baseado em compilação "estática", onde arquivos .class são usados para gerar código nativo antes da execução de um programa. Manta implementa um sistema RMI baseado em compilação estática, onde serializadores e desserializadores são gerados estaticamente para cada método remoto. Para ser capaz de se comunicar com uma máquina virtual que não utiliza essas otimizações, Manta também oferece o protocolo Java RMI como especificado pela Sun [57]. Quando Manta está executando programas de computação paralela com outras máquinas Manta, ele utiliza o protocolo Manta RMI. Quando Manta se comunica com máquinas JDK, ele utiliza o protocolo Java RMI. A figura 3.6 ilustra a interação de uma máquina Manta com uma máquina JDK e com outra máquina Manta.

O desempenho alcançado no sistema Manta chega a ser mais de uma ordem de magnitude superior ao do Java RMI. As características do protocolo Manta RMI responsáveis pelo seu bom desempenho são:

- Comunicação de baixo-nível mais eficiente: enquanto que Java RMI utiliza TCP/IP, que é adequado para aplicações baseadas em requisição e resposta, Manta utiliza bibliotecas de comunicação baseadas em C, especializadas para comunicação paralela;

- O protocolo RMI: o protocolo Manta RMI é implementado inteiramente em $\mathrm{C}$ e evita as camadas de stream de Java, o que minimaliza a quantidade de dados copiados em uma invocação remota. Além disso, o código que executa o protocolo Manta RMI é inteiramente nativo, ao contrário do JDK, onde o código do protocolo Java RMI é gerado por compiladores JIT;

- O protocolo de serialização: ao invés de usar a tecnologia de reflexão de Java [34], Manta RMI estaticamente gera serializadores e desserializadores específicos para cada método antes da execução de um programa. Um método cujo código não está presente em Manta no momento da sua execução é carregado 
dinamicamente, usando a técnica de conserva [69]. Serializadores e desserializadores específicos são dinamicamente compilados para esse método quando o seu código chega em Manta, para uso em futuras invocações.

Uma outra linha de pesquisa recentemente desenvolvida em Manta envolve a replicação de objetos e o uso de broadcasts atômicos e totalmente ordenados [51,52] para manter as réplicas consistentes. O modelo de replicação usado por Manta é baseado na técnica ROWA [6]: métodos que não modificam o estado de um objeto são executados localmente e métodos que alteram o seu estado utilizam o mecanismo de broadcast para manter suas réplicas consistentes. O modelo de replicação implementado em Manta foi projetado para ser integrado ao protocolo Manta RMI e portanto a invocação de um método de um objeto replicado tem a mesma sintaxe de uma invocação remota de um objeto não-replicado. Experimentos realizados mostram que o mecanismo de replicação de Manta é eficiente para várias classes de aplicações, inclusive para sistemas que utilizam redes de grande acesso [51].

Embora Manta RMI demonstre um desempenho de até uma ordem de magnitude superior ao do Java RMI [53], uma desvantagem desse protocolo é que ele não é portátil, por ter sido implementado especificamente para o sistema Manta.

\subsubsection{Filterfresh}

Filterfresh [2] é um pacote Java que dá suporte para a construção de servidores replicados tolerantes a falhas. Filterfresh utiliza um serviço de nomes replicado - uma extensão do serviço rmiregistry -, cujas réplicas são mantidas consistentes através de broadcasts atômicos e totalmente ordenados, mesmo em presença de falhas.

O registro rmiregistry (registro RMI) é um serviço de nomes simples fornecido por Java RMI. Ele permite que servidores registrem objetos através da operação bind. Um cliente pode obter uma referência para um objeto remoto por meio do método lookup. O registro mantém uma tabela que associa nomes (objetos String) a implementações de um objeto e executa em uma porta conhecida, geralmente a 1099.

O registro RMI só permite que objetos "locais" possam ser registrados, ou seja, chamadas ao método bind só podem ser realizadas por processos residentes na mesma máquina do registro RMI. Essa semântica restringe o uso de técnicas de tolerância a falhas em servidores. Além disso, ela dificulta a migração de objetos, já que Java RMI não fornece nenhum método para descobrir a localização de um objeto.

Filterfresh investiga três técnicas para resolver esses problemas: (1) a replicação de servidores, (2) a replicação do serviço de nomes e (3) uma nova camada de referência do lado do cliente. Em (1), quando um servidor é replicado, uma referência para a nova réplica é registrada no serviço de nomes replicado, sob o mesmo nome das demais 
réplicas. O serviço de nomes mantém uma tabela com a localização de todas as réplicas de um servidor com o mesmo nome. Quando uma servidor falha, invocações enviadas a ele são redirecionadas transparentemente para uma das suas réplicas, como explicado a seguir. Atualmente, Filterfresh só oferece replicação de servidores que não possuem estado (stateless), ou seja, que não precisam ser mantidos consistentes. A técnica (2) propõe que cada servidor possua uma réplica local do serviço de nomes, que é mantida altamente consistente (de acordo com os critérios de one-copy-serializability) com as demais réplicas. Para localizar um objeto remoto, um cliente invoca uma operação lookup local, fornecendo o nome do objeto. Caso o objeto tenha sido registrado em algum servidor, Filterfresh garante que lookup retornará uma referência para esse objeto. O mecanismo (3) propõe a definição de uma nova camada de referência do lado do cliente, que utiliza o serviço de nomes replicado para mascarar falhas nos servidores. Quando um cliente executa uma invocação em um servidor que não está mais executando, uma exceção é gerada remotamente. Ao invés de repassar essa exceção ao cliente, a nova camada de referência tenta localizar uma réplica do servidor e reexecuta o método transparentemente.

Uma desvantagem do Filterfresh é que ele não é compatível com o protocolo Java RMI e portanto não fornece suporte para aplicações construídas com o uso dessa tecnologia sem que haja a necessidade de modificá-las.

\subsection{Alternativas para Java RMI}

Várias alternativas ao uso de Java RMI têm sido propostas para a comunicação entre objetos Java residentes em máquinas virtuais distintas. Javaparty $[65,66]$ permite que aplicações multi-threaded construídas para SMPs sejam facilmente executadas em máquinas com memória distribuída. Para isso, uma nova palavra chave, remote, foi introduzida para identificar classes cuja implementação não se encontra localmente. Javaparty implementa todos os detalhes de comunicação transparentemente entre objetos remotos; a aplicação usuária só precisa identificar as classes que devem ser declaradas remote.

A partir da versão 1.3 do JDK, a Sun incorporou a implementação de um $O R B$ (Object Request Broker) à API (Application Programming Interface) do Java. Isso elimina a necessidade do licensiamento e da distribuição de ORBs Java específicos para que aplicações Java possam se comunicar com sistemas que utilizam o padrão CORBA [28].

Por fim, modelos de memórias compartilhadas distribuídas, onde não é necessário serializar o estado de objetos, têm sido propostos. Um exemplo é o sistema Java/DSM [81], que estende Treadmarks [44]. A camada de DSM lida com todos os aspectos relativos à comunicação entre máquinas virtuais distintas transparentemente. 


\section{Capítulo 4}

\section{O Sistema RMIRep}

A tecnologia Java RMI tem se tornado altamente popular porque oferece um ambiente simples e portátil para o desenvolvimento de objetos distribuídos. Java RMI, no entanto, não possui nenhum suporte para a replicação e consistência de objetos remotos e só implementa a semântica de objetos não-replicados (unicast). Uma aplicação que queira dar suporte a sistemas de informação distribuídos em redes de alta latência através da replicação de dados deve utilizar algoritmos de consistência para gerenciar seus objetos replicados, adicionando ao seu custo e complexidade. Essas aplicações se beneficiariam amplamente de uma camada de middleware que fornecesse replicação automática de dados e uma interface de alto nível para objetos replicados similar à que Java RMI fornece para objetos não-replicados.

Embora sistemas com suporte para a replicação transparente de objetos ofereçam muitas vantagens, há aplicações que gostariam de influenciar na maneira como os dados são replicados e mantidos consistentes. Por exemplo, uma ambulância móvel talvez possa esperar um intervalo máximo de 3 minutos para atualizar seus dados sobre o trânsito de São Paulo, enquanto que um motorista na marginal Tietê provavelmente tem uma tolerância de tempo maior. Sistemas que oferecem políticas de consistências "prontas" (black-box), que o usuário não possa configurar, são inadequadas para esse tipo de aplicação.

Há um compromisso, portanto, entre a flexibilidade desejada por aplicações quanto à replicação e consistência de dados e o custo e a complexidade de desenvolver, junto à aplicação usuária, políticas de consistência que satisfaçam as suas necessidades específicas.

O sistema RMIRep foi projetado para mitigar essa tensão de interesses. RMIRep estende a hierarquia Java RMI e tem como objetivo implementar replicação semitransparente de objetos distribuídos Java, com políticas de consistência variáveis, a serem escolhidas pela aplicação. Uma vez que a política seja escolhida, RMIRep 
provê mecanismos transparentes de replicação e consistência entre objetos. A principal política do RMIRep é Bayou, uma política de consistência fraca descrita na sessão 2.3. Bayou fornece flexibilidade ainda maior às aplicações usuárias por meio das políticas de usuário, que permitem a configuração de parâmetros de baixo nível que dizem respeito à propagação dos dados.

Os principais requisitos que guiaram o projeto e a implementação do RMIRep foram:

- Facilidade de uso: a maneira pela qual a aplicação usuária escolhe a política de replicação e consistência deve ser intuitiva e ter um impacto mínimo na forma com que o programador usualmente desenvolve suas aplicações distribuídas;

- Modularidade: a funcionalidade da replicação deve ser implementada em módulos e integrada modularmente às camadas já existentes do Java RMI. Aplicações projetadas para uso no Java RMI devem poder executar no sistema RMIRep sem que, para isso, sejam necessárias alterações no código dessas aplicações;

- Compatibilidade: alterações futuras feitas no suporte básico de Java para objetos distribuídos não devem requerer mudanças no sistema;

- Escalonamento: não deve haver uma queda de desempenho dramática relativa ao aumento no número de réplicas no sistema;

- Desempenho: o sistema deve ser capaz de executar em redes de banda estreita e na presença de falhas temporárias de alguns dos servidores (possivelmente todos).

Consideramos duas maneiras de integrar a funcionalidade do sistema RMIRep à tecnologia Java RMI: integração no nível da camada de referência remota e integração no nível de aplicação. Como veremos, a principal vantagem de trabalhar no nível da camada de referência é o aumento no desempenho. As desvantagens incluem complexidade de codificação maior e redução de compatibilidade com futuras versões do RMI.

\subsection{Projeto Inicial: Integração no Nível da Camada de Re- ferência Remota}

As interfaces RemoteRef e ServerRef e as suas implementações ${ }^{1}$ correspondem à $^{-}$ camada de referência remota da tecnologia RMI. Essa camada é responsável por gerenciar referências a objetos remotos, além de acionar e despachar invocações remotas.

\footnotetext{
${ }^{1}$ No JDK da Sun, essas implementações correspondem às classes UnicastRef e UnicastServerRef.
} 


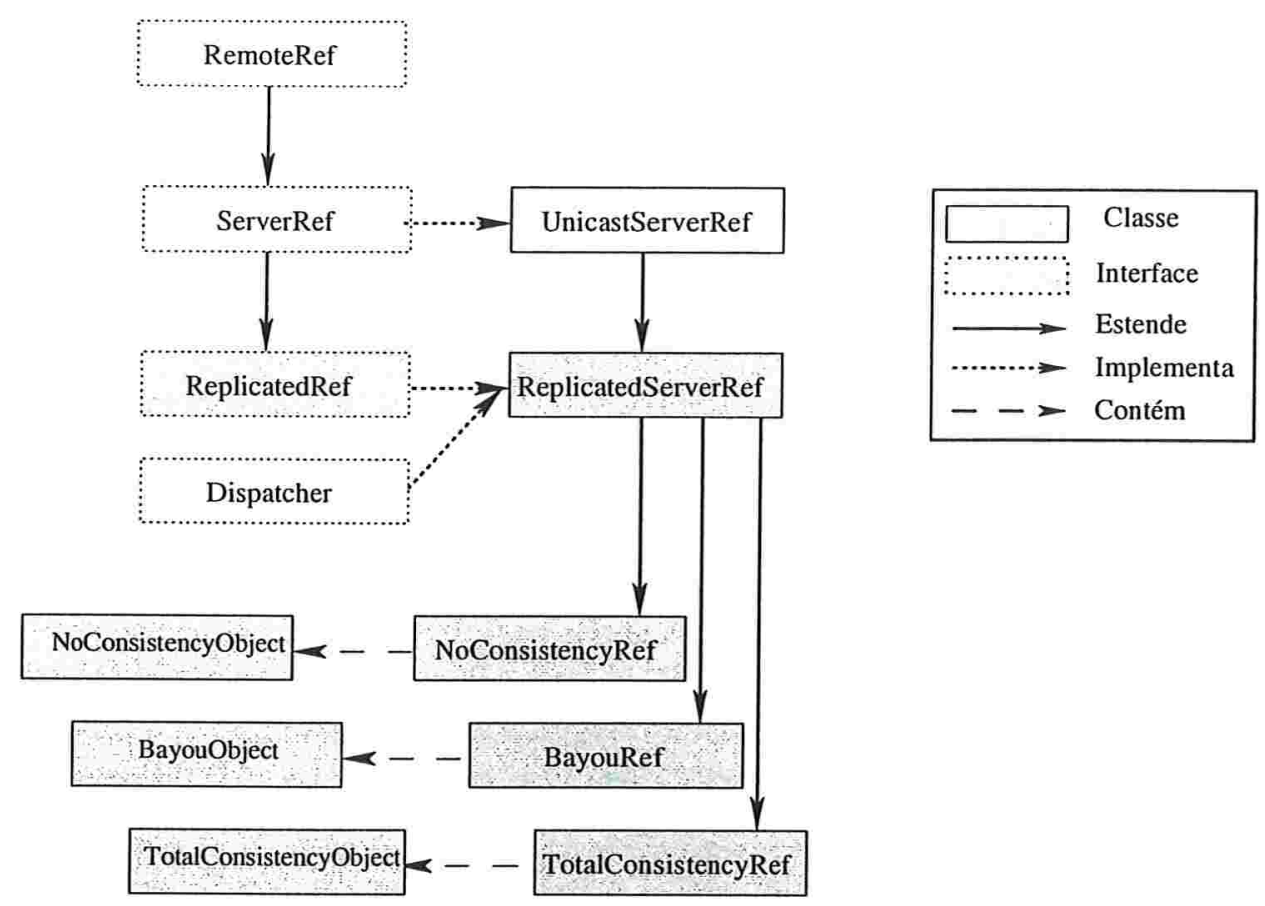

Figura 4.1: Hierarquia de classes original do RMIRep

Experimentos realizados pelos grupos de pesquisa Manta $[53,54]$ e Javaparty $[61,66]$ mostram que a sobrecarga do protocolo de serialização [56] em uma invocação remota corresponde a $35-42 \%$ do tempo total da invocação, enquanto que a sobrecarga imposta pelo protocolo Java RMI em si equivale a aproximadamente $35 \%$ do tempo total. Esse último componente inclui o tempo gasto para iniciar uma invocação no cliente, interceptá-la na camada de transporte do servidor, passá-la para a implementação do objeto e retornar o seu resultado para o cliente.

Com o objetivo de aumentar a eficiência dos protocolos utilizados pelo RMIRep, nossa primeira tentativa de implementação desse sistema buscou integrar sua funcionalidade à camada de referência remota do RMI. A camada de referência remota é o melhor lugar para adicionar essa funcionalidade porque é ali onde o empacotamento, o desempacotamento e a serialização dos parâmetros ocorrem. Portanto, quando uma invocação a múltiplos objetos é realizada, o tempo agregado do empacotamento, desempacotamento e serialização dos parâmetros da invocação é reduzido drasticamente. Nessa sessão apresentamos resumidamente o projeto inicial do sistema RMIRep e discutimos as razões pelas quais decidimos seguir outra abordagem.

A figura 4.1 mostra a hierarquia de classes do sistema RMIRep do projeto inicial. As classes representadas com caixas brancas fazem parte da hierarquia de classes do Java RMI. Nesta proposta, criamos a interface ReplicatedRef e a classe 
ReplicatedServerRef, que juntas definem um arcabouço para referências remotas de um objeto remoto replicado (ORR). ReplicatedServerRef mantém uma lista de réplicas (possivelmente inativas ${ }^{2}$ ) do ORR em questão e ReplicatedRef define métodos para que réplicas possam ser adicionadas e removidas do grupo de consistência do ORR. Além disso, ReplicatedServerRef provê métodos para a serialização do estado de objetos que serão replicados. A replicação e consistência dos dados não é abordada na implementação de ReplicatedServerRef: cada política de consistência define uma classe que estende ReplicatedServerRef e que lida com essas questões, como explicado a seguir.

Considere uma política de consistência qualquer, que chamamos de Policy. Policy é implementada no RMIRep pelo par de classes PolicyObject e PolicyObjectRef. PolicyObjectRef estende ReplicatedServerRef e é responsável por desencadear ações de consistência quando métodos são invocados no ORR correspondente. Em particular, PolicyObjectRef deve redefinir o método Dispatcher.dispatch, que, durante uma invocação remota, intercepta a chamada da camada de transporte e a delega à implementação do objeto (sessão 3.2.3). Usando a sua lista de réplicas, PolicyObjectRef invoca ações de consistência de acordo com os critérios que PolicyObject define. PolicyObject é a classe equivalente a UnicastRemoteObject no sistema RMI, ou seja, ela é a classe que aplicações usuárias devem estender para tornarem seus objetos replicáveis. Por exemplo, se uma aplicação estiver interessada na política de consistência Bayou, então seus objetos devem estender a classe BayouObject.

\subsubsection{Problemas no Projeto Inicial}

Nossa tentativa de integrar os módulos de replicação e consistência no nível da camada de referência remota do Java RMI não obteve sucesso. Java RMI instancia a referência de um objeto remoto em tempo de execução, de acordo com o nome fornecido pelo objeto ${ }^{3}$. Na interface RemoteRef há um campo final (final packagePrefix) que define o pacote onde a classe dessa referência se encontra. $\mathrm{Na}$ implementação do JDK 1.2.2, esse pacote é sun.rmi.server. Essa constante, por ser final, não pode ser redefinida por ReplicatedRef. Portanto, para que o ambiente de execução do Java RMI possa localizar nossas classes, elas devem estar presentes no pacote sun.rmi.server. Caso contrário, ao inicializar PolicyObject, o ambiente de execução do Java gera uma exceção (ClassNotFoundException) por não ter conseguido encontrar a implementação de PolicyObjectRef. Adicionar novas classes ao pacote de distribuição da API do Java comprometeria seriamente a facilidade de uso e a por-

\footnotetext{
${ }^{2}$ Há algumas classes de políticas que permitem que réplicas não participem ativamente do grupo de consistência em determinados momentos. Políticas de consistência fraca são um exemplo.

${ }^{3}$ Por exemplo, UnicastRemoteObject fornece o nome da classe UnicastServerRef, que representa a sua referência remota.
} 
tabilidade do sistema, pois as bibliotecas de Java teriam que ser modificadas na JVM de cada usuário.

Diante desse problema, nós consideramos outras alternativas, como fornecer um novo pacote de invocação remota de métodos, ou modificar partes do pacote RMI existente. Além de apresentar problemas adicionais, essas alternativas violam em grande parte as diretrizes que utilizamos para construir esse projeto. Em particular, fornecer um novo pacote de replicação impossibilita que aplicações Java RMI existentes possam usar o nosso sistema. Modificar a hierarquia atual de classes do Java RMI afeta a facilidade de uso do sistema, além de comprometer sua compatibilidade com futuras versões do Java RMI e ter o potencial de introduzir erros em programas existentes que já usam suas classes.

Por causa dessas razões, decidimos implementar o RMIRep no nível da camada de aplicação.

\subsection{Projeto Final: Integração no Nível da Camada de Apli- cação}

Nessa sessão apresentamos o projeto final e a implementação do sistema RMIRep no nível da camada de aplicação. RMIRep utilizou as classes do sistema Java RMI para implementar sua funcionalidade, como uma aplicação distribuída Java normalmente o faria.

\subsubsection{A Hierarquia de Classes}

A figura 4.2 mostra as principais classes e interfaces do sistema RMIRep. A seguir explicamos brevemente cada uma delas.

\section{Interface ReplicatedRemote}

A interface ReplicatedRemote define a funcionalidade que todo ORR deve implementar. Especificamente, essa interface contém apenas um método, que retorna uma réplica do objeto remoto.

\section{Classe ReplicatedRemoteObject}

Essa classe implementa ReplicatedRemote e define o arcabouço de um ORR. ReplicatedRemoteObject mantém uma lista de réplicas (possivelmente inativas) do 




Figura 4.2: Hierarquia de classes do RMIRep

ORR correspondente e fornece métodos para que réplicas sejam adicionadas ou removidas do grupo de consistência. Além disso, essa classe fornece métodos para serializar o estado de um objeto a ser replicado.

\section{Interface NoConsistency}

Essa interface define os métodos necessários à política de consistência de réplicas independentes (sessão 2.1). Daqui em diante nos referimos a essa política como NoConsistency.

\section{Classe NoConsistencyObject}

Essa classe implementa a política de consistência NoConsistency. Essa política não define nenhuma ação de consistência entre réplicas, permitindo que os seus estados divirjam. No entanto, porque NoConsistencyObject estende ReplicatedRemoteObject, ela herda métodos para que o grupo de consistência do ORR correspondente seja mantido atual, recebendo notificações de réplicas que entram e saem do grupo de consistência. Isso é necessário porque, embora um objeto com política NoConsistency não precise ter uma visão atualizada das réplicas no sistema, a sua política de consistência pode mudar e a nova política provavelmente precisará dessa informação. De fato, nós assumimos que a vasta maioria das políticas de consistência precisa ter conhecimento das demais réplicas e por isso implementamos o gerenciamento de entrada e saída de réplicas na classe ReplicatedRemoteObject, que todas as políticas devem estender. 
Interface TotalConsistency $2.2)$.

Essa interface define os métodos necessários à política de consistência total (sessão

\section{Classe TotalConsistencyObject}

Essa classe implementa a política de consistência total. Essa política define o maior grau de consistência entre as réplicas. Ela se utiliza de um lock para implementar uma visão sincronizada dos dados (one-copy serializability [18]). Além disso, TotalConsistency herda métodos para que o grupo de consistência do ORR correspondente seja mantido atual, recebendo notificações de réplicas que entram e saem do grupo de consistência.

\section{Interface BayouClientInterface}

Essa interface define todos os métodos da política Bayou que são acessíveis às aplicações usuárias. Em particular, BayouClientInterface define métodos para a configuração das políticas de usuário do Bayou e para a chamada de operações que a política Bayou fornece, como a aposentadoria de uma réplica ou uma sessão de antientropia. A definição da interface BayouClientInterface encontra-se no apêndice A.1.

\section{Interface Bayou}

Essa interface define métodos relacionados com o protocolo de anti-entropia e com a criação de réplicas Bayou. Essa interface não contém métodos para que réplicas sejam notificadas sobre a entrada e saída de outras réplicas do grupo de consistência, já que Bayou faz isso relaxadamente (lazily) através do protocolo de anti-entropia ${ }^{4}$. A definição da interface Bayou encontra-se no apêndice A.2.

\section{Classe BayouObject}

Essa classe implementa a política de consistência Bayou. Ela utiliza um log para armazenar atualizações feitas por clientes ou recebidas através de anti-entropia. BayouObject implementa as interfaces BayouClientInterface e Bayou.

\footnotetext{
${ }^{4} \mathrm{Na}$ verdade, BayouObject estende a classe ReplicatedRemoteObject, que possui essa funcionalidade.
} 


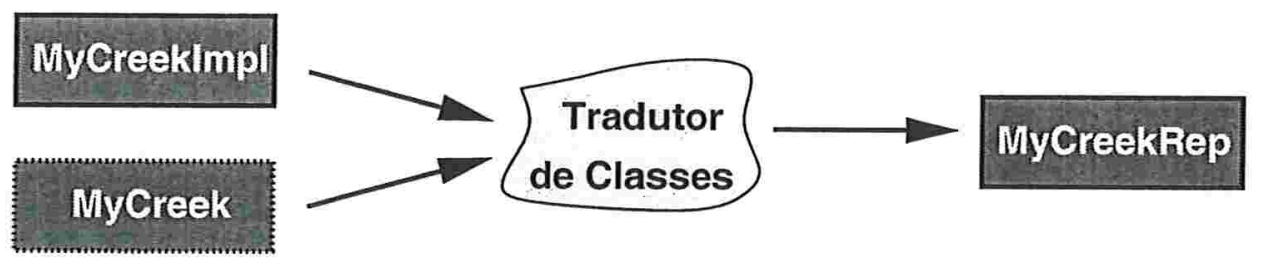

Figura 4.3: Tradução automática de classes remotas

\subsubsection{O Modelo Básico de Sistema}

Para que aplicações possam utilizar o sistema RMIRep, elas devem fornecer a implementação de um objeto remoto não-replicado Java. A aplicação implementa esse objeto sem considerar se ele será replicado ou não ${ }^{5}$. RMIRep fornece uma ferramenta Repc, que recebe como entrada os nomes da interface remota (por exemplo, MyCreek) e da implementação do objeto remoto (MyCreekImpl) e automaticamente gera uma classe (MyCreekRep) que pode ser replicada e que implementa MyCreek. A figura 4.3 demostra esse processo. A tradução automática de classes remotas é discutida na sessão 4.5 .

Há duas maneiras de inicializar um objeto replicado (uma instância de uma classe gerada por Repc): (1) iniciar um novo grupo de consistência, do qual o ORR sendo inicializado será o primeiro membro ou (2) adicionar o novo objeto a um grupo de consistência existente. No primeiro caso, três parâmetros adicionais, além dos exigidos pelo construtor do objeto remoto correspondente, são necessários: o nome para o ORR, o nome do host onde o ORR está sendo inicializado e o nome da política de consistência inicial do objeto. No segundo caso, o objeto também precisa saber a localização de alguma réplica do grupo de consistência existente e por isso é necessário dois outros parâmetros além dos já descritos: o nome de qualquer objeto remoto pertencente ao grupo de consistência ${ }^{6}$ e o nome do host onde esse objeto está residindo. Nesse caso, o objeto remoto recebe um pedido de criação e transfere o seu estado para o objeto requisitante, que entra em operação e daí em diante passa a receber as atualizações de outros servidores. Um novo objeto replicado tem a mesma política de consistência do ORR que o originou.

A política de consistência de um ORR pode ser mudada dinamicamente em qualquer momento. Quando um cliente desencadeia uma mudança de política, RMIRep propaga uma notificação de mudança de política para todos os servidores ativos. Essa notificação é feita através de um broadcast e exige que todos os servidores que participarão da mudança de política estejam ativos e conectados simultaneamente. Essa restrição pode ser facilmente relaxada para permitir que réplicas que não estejam co-

\footnotetext{
${ }^{5} \mathrm{~A}$ política de consistência Bayou pode precisar de um montante mínimo de código extra (sessão 4.7.3).

${ }^{6}$ Esse nome precisa ser o mesmo usado pelo ORR para se registrar junto ao serviço de nomes.
} 
nectadas no momento da mudança recebam uma notificação após serem reconectadas e reconciliem os seus estados adequadamente. Isso seria de grande importância se um grupo de réplicas com consistência fraca mudasse sua política para outro tipo de consistência fraca. Nesse caso, não seria razoável exigir que todas as réplicas do sistema estivessem conectadas simultaneamente. Na implementação atual do RMIRep, no entanto, as duas combinações de mudança de política esperadas (de Bayou para total e vice-versa) se baseiam no fato de que todas as réplicas do sistema estão simultaneamente conectadas (já que a política total exige isso) e por isso o protocolo atual usado por RMIRep funciona adequadamente. Todas as ações de usuário são bloqueadas durante o processo de mudança da política de consistência. Invocações realizadas pelos clientes durante esse processo são executadas, na ordem em que foram chamadas, imediatamente depois.

Nós utilizamos o padrão de arquitetura Whole-Part [11] para desenvolver a estrutura de um objeto replicado. Um ORR é formado por dois componentes principais, que descrevemos a seguir:

- Uma instância da classe de implementação do objeto remoto ${ }^{7}$ o ORR implementa a interface do objeto remoto e utiliza a técnica de delegação [25] para repassar as invocações para a implementação desse objeto;

- Objetos de consistência: Para cada política de consistência que RMIRep oferece, existe um objeto de consistência relacionado (por exemplo, BayouObject para a política Bayou, ver figura 4.2). Somente um desses objetos está ativado simultaneamente, o equivalente à política de consistência em vigor. O ORR utiliza os mecanismos de consistência fornecidos por esse objeto para manter seu objeto remoto consistente.

Nenhum dos objetos descritos acima é visível exteriormente. A aplicação usuária acessa os métodos do objeto remoto por meio da interface desse objeto, que o ORR implementa. No entanto, também é necessário que um ORR forneça a aplicações usuárias uma interface para seus objetos de consistência, porque há políticas (como Bayou) que permitem que aplicações configurem alguns dos seus parâmetros. O ORR fornece essa interface usando a técnica de delegação, repassando os métodos invocados para o objeto de consistência apropriado. A figura 4.4 mostra uma visão de altonível de um objeto remoto replicado com a política de consistência total. Os objetos sombreados estão desativados, ou seja, têm valor null.

\footnotetext{
${ }^{7} \mathrm{Na}$ verdade, cada ORR possui duas instâncias dessa classe, para simular visōes de objeto diferentes na política de consistência Bayou (sessão 4.7.3).
} 


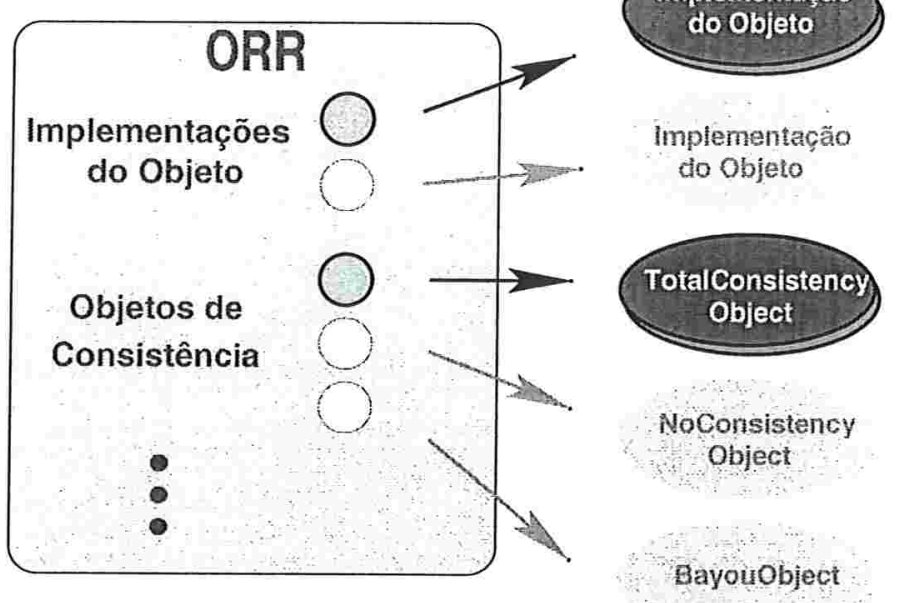

Figura 4.4: Um ORR com política de consistência total

\subsection{Implementação das Políticas Total e de Réplicas Indepen- dentes}

No contexto do RMIRep, uma atualização é definida como uma invocação de um método remoto de um objeto. Atualizações não são classificadas como read ou write pelo RMIRep ${ }^{8}$. Adotamos uma visão conservadora onde cada atualização tem o potencial de entrar em conflito com atualizações realizadas em outra réplicas. Essa decisão é excessivamente pessimista, já que é possível identificar métodos Java que possuem a semântica read-only $[36,46,51]$ e portanto nunca introduzem um conflito. No entanto, para favorecer a simplicidade do nosso código, decidimos não distinguir entre os possíveis tipos de atualização no nosso projeto.

\subsubsection{Política NoConsistency}

A política NoConsistency não oferece suporte automático para a consistência dos dados, no entanto ela permite que réplicas sejam adicionadas e removidas do grupo de consistência. A razão pela qual essa política gerencia uma lista de réplicas é para que, caso a política de consistência seja mudada, a nova política não precise requisitá-la a um outro servidor. Na verdade, se essa política não mantivesse um registro das outras réplicas, a política de consistência não poderia ser mudada, já que essa operação exige o

\footnotetext{
${ }^{8}$ Isso não impede que alguma política de consistência específica trace uma distinção entre os dois tipos de atualizações: a política Bayou, por exemplo, define tal distinção (sessão 4.7.6).
} 
envio de uma notificação a cada réplica do sistema que participará da mudança (sessão 4.4).

Quando um ORR com a política NoConsistency é inicializado a partir de um objeto remoto, ele recebe o estado desse objeto, que consiste somente da lista de réplicas do sistema. Quando uma nova réplica é adicionada ao grupo, NoConsistency realiza um broadcast a todas as demais cópias, para avisá-las da existência da nova réplica. Note que, por se utilizar de um método broadcast, NoConsistency assume que todas as réplicas estão simultaneamente conectadas. Isso é uma exigência inaceitável para a grande maioria das aplicações, especialmente aquelas que teriam interesse de utilizar NoConsistency. Assumidamente, por restrições de tempo e por não ser o enfoque do nosso projeto, resolvemos não desenvolver um mecanismo mais relaxado que esperasse por uma eventual reconexão das réplicas desconectadas para avisá-las sobre a nova réplica. No entanto, acreditamos que isso seria uma tarefa simples.

\subsubsection{Política Total}

A política de consistência total se utiliza de um lock para implementar uma visão sincronizada dos dados. O lock é um programa Java independente que possui localização conhecida por todos. Antes de executar uma invocação de um cliente, a política deve adquirir acesso ao lock através da chamada do método acquire. A consistência total dos dados é implementada ao restringir o acesso ao lock a uma réplica por vez. Isso é facilmente implementado em Java acrescentando a palavra chave synchronized ao método acquire. Uma vez de posse do lock, a réplica executa a invocação localmente e faz um broadcast para as demais réplicas. Quando todas as réplicas terminam de executar o método, o lock é liberado pelo método release. Esse processo é repetido para cada invocação de um cliente.

O estado da política total consiste somente da lista de réplicas do sistema. Ela utiliza o mesmo mecanismo de NoConsistency para adicionar réplicas ao grupo de consistência.

\subsection{Mudança Dinâmica da Política de Consistência}

Todo objeto replicado define o método remoto:

changePolicy(int newPolicy, Object state, String sender).

Esse método executa a mudança dinâmica da política de consistência de um grupo de réplicas. Quando um ORR decide mudar sua política, ele executa esse método localmente e depois nas demais réplicas. O parâmetro state contém quaisquer dados que 
tenham que estar consistentes em todas as réplicas antes que a mudança da política possa ser efetivada. Por exemplo, se um grupo de réplicas com consistência Bayou decidir mudar para a política total, é necessário que os estados de todas as réplicas estejam consistentes por causa da propriedade de serialização dos dados que a política total impõe (sessão 2.2). Nesse caso, state contém o estado da implementação do objeto remoto da réplica que desencadeou a mudança. Quando a nova política é NoConsistency ou Bayou, state é null: no caso de Bayou, a transferência do estado de sender está incorporada ao seu modelo de criação de réplicas e por isso não precisa ser diretamente lidado por changePolicy (sessão 2.3.6). Observe que, se a nova política for Bayou ou total, mudar o tipo de consistência de um grupo de réplicas requer transferência de um grande número de dados. Como esperado, essa operação não é escalável com relação ao número de réplicas no sistema, como veremos no capítulo 5 .

O mecanismo de mudança dinâmica da política de consistência não é muito flexível e exige mudanças na classe de um objeto replicado para que novas políticas de consistência possam ser adicionadas ao RMIRep. Em outras palavras, o mecanismo que efetua a mudança da política é hard-coded na classe do objeto remoto replicado.

\subsection{O Tradutor de Classes Remotas}

O sistema RMIRep fornece uma ferramenta, Repc, que permite a geração automática de classes de ORRs a partir da interface remota de um objeto e da sua implementação. A tradução de uma classe remota consiste de duas fases: a criação de métodos estáticos, que não dependem da interface e da implementação do objeto remoto e a criação de métodos dinâmicos, que variam de acordo com a interface e a implementação passadas ao tradutor. Para criar os métodos estáticos, o tradutor lê um arquivo que contém as suas definições. Esse arquivo é fornecido como parte da distribuição de RMIRep. Para criar os métodos dinâmicos, o processo de tradução utiliza a tecnologia de reflexão Java [34] para obter informações sobre os métodos da interface remota, gerando métodos correspondentes na classe replicada. A implementação de cada um desses métodos delega a invocação para o objeto de consistência em vigor, que invoca o método na implementação do objeto.

Após criar arquivos com o código fonte da classe replicada, Repc os compila e gera o arquivo .class correspondente. Os arquivos com o código fonte gerados por Repc são apagados, a não ser que o usuário especifique o contrário.

Atualmente, Repc suporta a tradução de objetos que implementem somente uma interface remota. Estender o tradutor para que ele suporte cenários mais flexíveis, que envolvam múltiplas interfaces remotas, é uma tarefa simples. 


\subsection{Restrições na Arquitetura de um ORR}

A arquitetura de um objeto replicado não é muito flexível. Idealmente, novas políticas de consistência deveriam poder ser criadas e utilizadas por objetos replicados construídos por Repc sem precisar alterar a classe do ORR. Para isso, o ORR teria que se comunicar com as políticas de consistência de maneira uniformizada, possivelmente através de uma interface que cada política de consistência implementaria. No entanto, isso representa um desafio por causa da grande variedade de políticas existentes, que impõem exigências variadas no ORR que deve gerenciá-las. O desafio existe porque as políticas de consistência são criadas estaticamente e não têm acesso à implementação do objeto remoto que será replicado. Esse objeto se encontra uma camada acima, na classe do ORR, criada dinamicamente. Essa classe deve permitir que a política de consistência altere a implementação do objeto remoto de acordo com a sua especificação de consistência, que varia muito entre políticas diferentes. Além disso, porque as políticas de consistência não são diretamente acessíveis ao usuário, a classe do ORR deve fornecer uma interface para cada uma delas, delegando invocações realizadas pelo usuário à política apropriada. Criar uma interface que definisse um padrão de comunicação entre a classe do ORR e as políticas de consistência seria um trabalho interessante de extensão do RMIRep.

\subsection{Implementação da Política Bayou}

A política de consistência Bayou foi adaptada e implementada no sistema RMIRep. Essa sessão descreve e discute as diferenças de semântica da política Bayou construída no Xerox PARC e da política Bayou do RMIRep. Na nossa implementação, somente um subconjunto das propriedades do sistema Bayou foi implementado. Em particular, não lidamos com questões relacionadas com segurança, garantias de sessão (sessão 2.3.5), suporte para transações, a escolha do servidor do qual criar uma nova réplica (sessão 2.3.8) e a escolha de réplicas com as quais o cliente pode se comunicar (sessão 2.3.7).

\subsubsection{O Conceito de Cliente e Servidor}

O sistema Bayou fornece uma arquitetura de cliente-servidor flexível, que pode ser usada para simular uma topologia ponto-a-ponto, onde servidores possuem réplicas do banco de dados e prestam serviços a clientes interessados em acessar tal informação. A conexão entre clientes e servidores é feita por meio de RPC.

No sistema RMIRep, nós adotamos uma arquitetura diferente: objetos replicados são clientes e servidores simultaneamente. Quando um servidor decide fazer uma réplica de um objeto remoto, RMIRep instancia um ORR nesse servidor. Esse ORR funciona 
como um cliente, recebendo invocações da aplicação usuária e como um servidor, enviando atualizações de consistência a outras réplicas. Nossa decisão foi baseada em duas observações: (1) a sobrecarga de espaço que as estruturas de replicação e consistência impõem ao objeto remoto não são grandes e portanto computadores móveis não terão problema em comportá-los no seu sistema ${ }^{9}$; (2) o conceito de banco de dados usado em Bayou não faz sentido no RMIRep, já que no nosso sistema lidamos com objetos transientes, cujas operações não envolvem tantos recursos do sistema como um banco de dados.

\subsubsection{O Modelo de Sistema Básico da Política Bayou}

Assim como os procedimentos de Bayou, os métodos de objetos remotos no RMIRep devem ser completamente determinísticos para que, em algum momento no futuro, as réplicas possam estar consistentes. No contexto do Bayou, um método é determinístico se as mudanças no estado do objeto produzidas por ele não dependem de dados relacionados com o tempo, como o resultado de System.currentTimeMillis ou de informação específica a um servidor, como o seu nome. Além disso, caso um desses métodos falhe por limitações no uso da CPU ou de outros recursos, ele deve falhar deterministicamente.

Bayou permite que a aplicação usuária defina, para cada método do presente na interface do objeto remoto, dois métodos adicionais: doCheck e doMerge. Esses métodos são equivalentes aos procedimentos check e merge apresentados na sessão 2.3.2. A definição de métodos para detecção e resolução de conflitos é opcional para cada método.

Bayou utiliza a API do Java a fim de implementar estruturas de dados para representar atualizações, vetores de versão, identificadores dos servidores, etc. Embora tenhamos nos esforçado para implementar estruturas de dados e algoritmos eficientes, há espaço para torná-los ainda mais econômicos e rápidos. Em particular, o tamanho da estrutura de dados que representa uma atualização (a classe Write) é relativamente grande, em parte pela representação de objetos de Java [49] e em parte pela nossa implementação.

O protocolo de anti-entropia implementado no RMIRep é essencialmente igual ao desenvolvido no Xerox PARC. A figura 4.5 mostra esse protocolo.

\footnotetext{
${ }^{9} \mathrm{O}$ tamanho aproximado das estruturas relacionadas com a replicação dos dados é de 3 Kbytes em um sistema com 1 réplica e de 11 Kbytes em um sistema com 100 réplicas.
} 


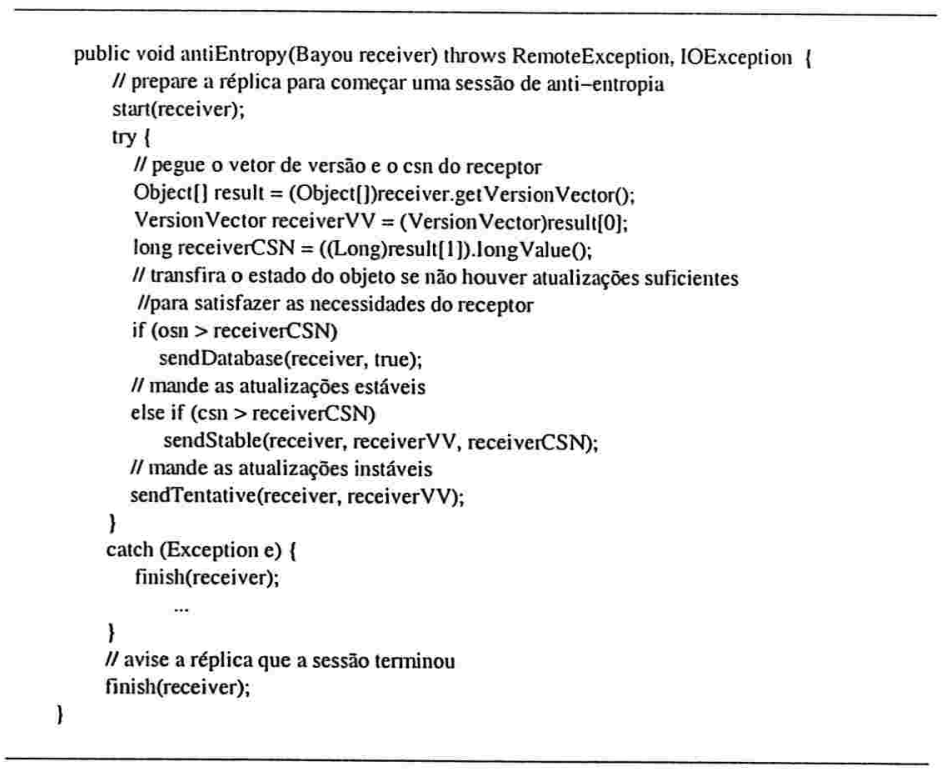

Figura 4.5: O protocolo de anti-entropia com suporte para propagação e exclusão de atualizações estáveis

\subsubsection{Detecção e Resolução de Conflitos}

Uma atualização é criada quando um cliente executa um método em um objeto remoto. Ela é formada pelos métodos do, doCheck e doMerge. O tradutor de classes remotas detecta, para cada método, se a aplicação usuária definiu os métodos doCheck e doMerge para o método do.

RMIRep impõe algumas restrições aos métodos doCheck e doMerge. Algumas delas não são verificadas pelo tradutor de classes remotas em tempo de compilação. A não observância dessas restrições não causa erros fatais na operação de Bayou, no entanto pode comprometer a consistência entre as réplicas. As restrições impostas por Bayou são as seguintes:

- Se um dos métodos doMerge ou doCheck for definido, o outro também deve ser definido, caso contrário o tradutor de classes gera uma exceção;

- O método doCheck deve retornar um objeto boolean, caso contrário o tradutor de classes gera uma exceção. Isso faz com que a semântica desse método seja equivalente ao do procedimento check. Se o resultado do método for true, do é executado, caso contrário doMerge é invocado;

- O método doMerge deve ter a semântica read-only, ou seja, ele não deve alterar o estado do objeto remoto. Essa restrição não é verificada pelo sistema; 


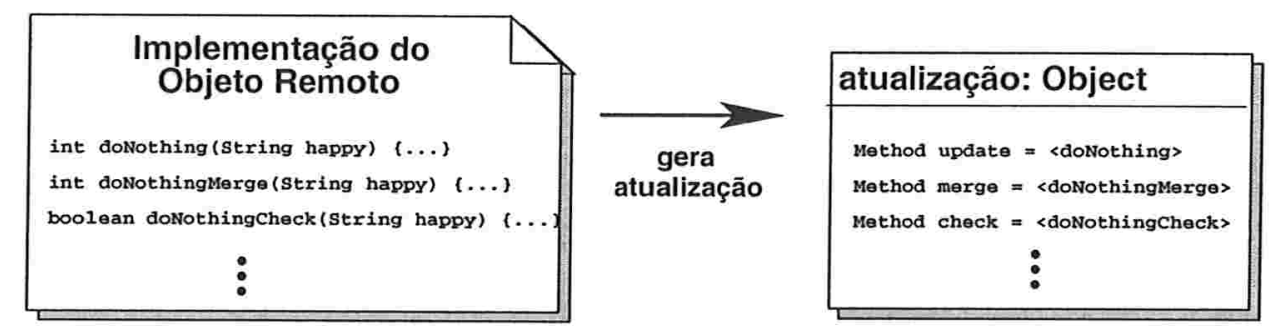

Figura 4.6: Atualização gerada para método que suporta detecção e resolução automática de conflitos

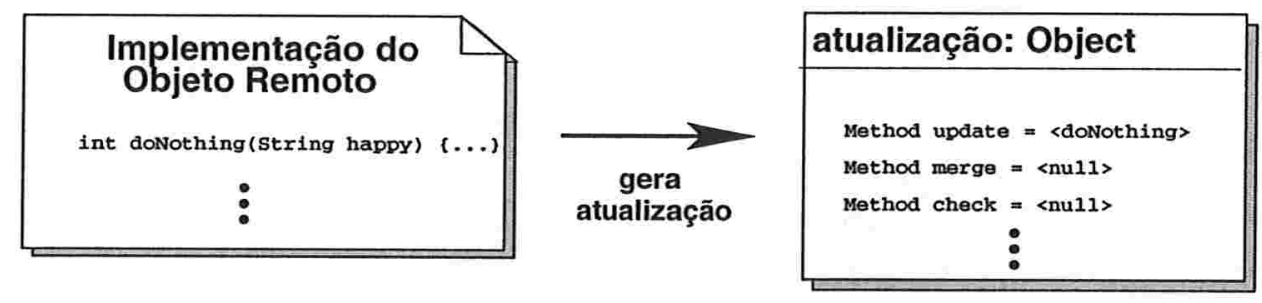

Figura 4.7: Atualização gerada para método que não suporta detecção e resolução automática de conflitos

- Caso os métodos doMerge e doCheck tenham sido definidos, eles devem conter exatamente os mesmos parâmetros que do, na mesma ordem. Além disso, doMerge deve retornar o mesmo tipo de objeto que do retorna. Essa restrição simplifica bastante o projeto e a implementação do mecanismo de deteç̧ão e resolução de conflitos, sem diminuir o poder computacional desses métodos. Além disso, essa restrição reduz o tamanho das atualizações propagadas, que não precisam conter parâmetros distintos para cada um desses três métodos.

Seria trivial incorporar a funcionalidade dos métodos do, doCheck e doMerge em um só método. No entanto, decidimos mantê-los separados para que a semântica da nossa política fosse a mais parecida possível com a do modelo definido pelo sistema Bayou e, principalmente, por causa de transparência: usuários devem ser capazes de definir a funcionalidade de um objeto remoto sem se preocupar se esse objeto será replicado ou não. O usuário só precisará implementar os métodos doCheck e doMerge para um determinado método se, no futuro, ele decida tornar o objeto replicável e se houver interesse na deteç̧ão de conflitos para esse método. As figuras 4.6 e 4.7 mostram duas implementações de um objeto que define o método remoto doNothing e as atualizações que RMIRep gera para cada uma dessas versões quando doNothing é executado por um cliente. 


\subsubsection{Sincronização}

A implementação atual do RMIRep contém algumas restrições relativas à sincronização de dados. Em particular, uma réplica só pode estar envolvida em uma sessão de anti-entropia por vez. Além disso, invocações feitas por clientes e sessões de antientropia são operações mutualmente exclusivas. Quando um cliente quer executar um método e o ORR está realizando uma sessão de anti-entropia, a execução do método é bloqueada e só é liberada após o término do protocolo.

Essas restrições podem ser removidas com um projeto cuidadoso de sincronização das estruturas de dados da política Bayou. Optamos por implementar um modelo de sincronização mais simples e restritivo.

\subsubsection{Desfazer e Refazer Operações (Roll backs)}

Uma das principais diferenças entre a nossa política Bayou e a desenvolvida no Xerox PARC diz respeito a desfazer e refazer atualizações do $\log$ de uma réplica. Como vimos na sessão 2.3.4, uma réplica precisa ser capaz de desfazer e refazer atualizações para que elas possam ser reordenadas e reexecutadas de acordo com uma ordem global de serialização.

O sistema Bayou original dispõe de um gerenciador de banco de dados que implementa rotinas para desfazer e refazer atualizações atomicamente. O sistema RMIRep precisa implementar uma solução equivalente para poder desfazer e refazer métodos realizados em objetos remotos. Decidimos manter duas cópias do objeto remoto no ORR, como mostra a figura 4.4. Um desses objetos é desativado (recebe o valor de null) quando a política de consistência do ORR não é Bayou.

Além de fornecer uma solução para o problema em questão, manter duas implementações do objeto remoto permite oferecer duas visões do estado desse objeto à aplicação usuária. Quando um ORR recebe uma atualização por meio de anti-entropia, ele aciona a política de consistência Bayou para lidar com a atualização e passa as duas implementações do objeto remoto (objetos estável e instável) a ela. O objeto estável reflete somente as atualizações estáveis executadas nesse servidor, enquanto que o objeto instável corresponde a todas as atualizações conhecidas por essa réplica. O nome instável vem do fato que o estado desse objeto pode vir a mudar devido a uma possível reordenação das atualizações instáveis. Bayou reordena suas atualizações se, ao receber uma nova atualização $a$, o identificador de $a$ for menor do que o de alguma atualização existente no seu $\log$. A nova atualização é inserida no $\log$ de acordo com a nova ordem.

Quando uma atualização precisa ser desfeita em um objeto remoto Bayou faz uma cópia do objeto estável e executa todas as atualizações instáveis, já reordenadas, nesse objeto. Dessa maneira, o objeto estável é usado para simular um checkpoint do objeto 
(a)

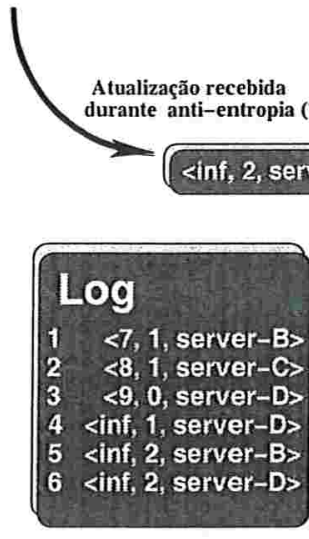

(b)

(c)
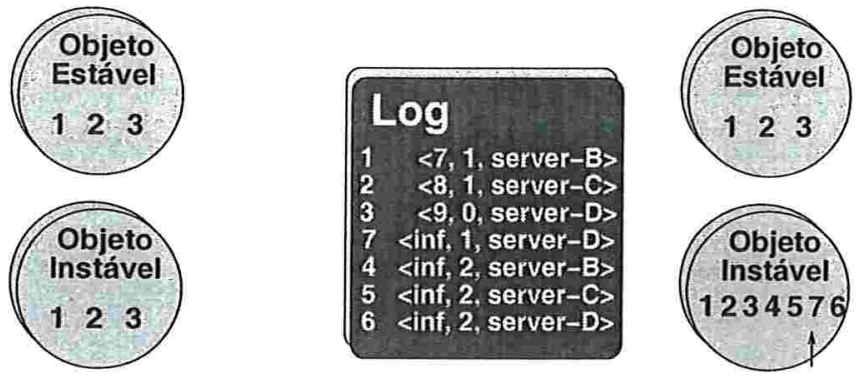

Figura 4.8: Reordenação de atualizações durante anti-entropia (a) Uma nova atualização (7) é recebida (b) Uma cópia do objeto estável passa a ser o novo objeto instável, o que é equivalente a desfazer as atualizações instáveis (4,5 e 6) (c) As atualizações 4, 5, 7 e 6 são refeitas, nessa ordem, no novo objeto instável

remoto, já que os métodos realizados no objeto estável nunca são reordenados e por isso nunca precisam ser reexecutados. Portanto, Bayou permite que atualizações sejam desfeitas de uma maneira equivalente a como aconteceria em um banco de dados que realizasse checkpoints do seu estado logo após a execução de cada atualização estável. O nosso mecanismo desfaz, na média, mais atualizações do que o necessário. Por exemplo, na figura 4.8, uma nova atualização (7) é recebida e somente a atualização 6 precisa ser desfeita. No entanto, a última atualização estável é a 3 e por isso as atualizações 4 e 5 também são desfeitas.

\subsubsection{Visões Estável e Instável}

Como descrito na sessão anterior, Bayou fornece duas visões do estado do objeto remoto às aplicações usuárias: visão estável, que reflete somente as atualizações estáveis e visão instável, que reflete todas as atualizações executadas na réplica. Bayou permite que uma aplicação usuária defina a visão do sistema em tempo de execução.

Quando uma aplicação escolhe a visão estável de Bayou, atualizações feitas por clientes continuam sendo realizadas no objeto instável. No entanto, o valor retornado ao cliente é o resultado dessa mesma atualização realizada no objeto estável. Essa técnica introduz um problema: em réplicas não-primárias, atualizações não podem ser realizadas no objeto estável até que elas se tornem estáveis. Para solucionar esse problema, introduzimos a exceção NotReadOnlyException. Se a aplicação tiver interesse em acionar a visão estável do seu objeto remoto, NotReadOnlyException deve 
ser incluída na cláusula throws de todos os métodos que não forem read-only. Se uma réplica não-primária acionar a visão estável dos dados e executar um método que não seja read-only, RMIRep gera a exceção NotReadOnlyException.

\subsubsection{O $\log$ de Bayou}

O $\log$ da nossa política Bayou é similar ao usado pela política Bayou original. No entanto, há duas diferenças principais. A primeira delas diz respeito às atualizações que são armazenadas nele. Uma atualização correspondente à invocação de um método do é composta por:

- Três objetos java.lang.reflect.Method, dois dos quais podem estar inativos (correspondentes aos métodos doMerge e doCheck);

- Os argumentos passados ao método do;

- O identificador da atualização, composto por um accept-stamp, um CSN e o identificador do servidor que gerou a atualização.

A segunda e mais importante diferença diz respeito à atomicidade de operações realizadas no $\log$ do RMIRep, que não fornece suporte para operações atômicas. Embora isso pudesse ser incluído no sistema com relativa facilidade, decidimos não fazê-lo, já que RMIRep não fornece suporte para objetos persistentes e por isso operações de log atômicas não adicionariam nenhuma robustez ao sistema: caso houvesse uma falha no servidor que deixasse o $\log$ inconsistente, o estado do ORR correspondente provavelmente também ficaria inconsistente. Como o RMIRep não provê suporte para checkpoints do estado de um objeto remoto, seria impossível recuperar algum estado consistente desse objeto.

Suporte para operações atômicas, checkpoints e objetos persistentes consiste em uma possível linha de trabalhos futuros em cima do RMIRep.

\subsubsection{Políticas de Usuário}

Nessa sessão descrevemos as políticas de usuário (sessão 2.3.7) presentes na nossa implementação do Bayou.

As políticas para quando realizar a reconciliação dos dados incluem sessões de antientropia manuais, desencadeadas pela aplicação usuária, sessões periódicas, com intervalo de tempo definido pela aplicação usuária e sessões desencadeadas pelo sistema quando o nível de inconsistência entre as réplicas (definido pela aplicação usuária) atingir um limite pré-definido. Essa última, que chamamos de MethodCount, é classificada 
por Lenz [48] como uma política de dimensão espacial com um predicado de consistência fraco. O predicado é o número de chamadas locais que um cliente pode invocar em um ORR até que ele tenha que realizar uma sessão de anti-entropia com alguma réplica.

As políticas disponíveis para a escolha da réplica com a qual se deseja realizar antientropia são a escolha aleatória de uma réplica e a definição de uma réplica específica. Essa última política, junto com MethodCount, permite que uma aplicação usuária escolha uma réplica qualquer e defina o grau máximo de variação de consistência entre essa réplica e a sua própria. Isso é particularmente útil em situações onde há um servidor em um grupo de réplicas que é de interesse especial para algum cliente. Um cenário onde essa combinação de políticas seria útil envolve um executivo que possui uma cópia da sua agenda eletrônica em filiais da sua empresa e no computador da sua secretária. Ao viajar, ele designa a réplica da sua secretária como a sua parceira de anti-entropia e resolve que todas as atualizações realizadas no seu laptop vão ser propagadas imediatamente para o computador da sua secretária (o predicado de MethodCount nesse caso seria 1).

A única política de exclusão de réplicas implementada no RMIRep é a manual, onde o usuário define a percentagem de atualizações a serem excluídas do log e desencadeia o processo de exclusão manualmente. 


\section{Capítulo 5}

\section{Testes e Resultados}

A implementação do sistema RMIRep contém 41 classes, 5451 linhas de código e se baseia inteiramente na API do Java JDK 1.2.2. Essa implementação executa nos sistemas operacionais Linux 2.4, SunOS 5.7 e Windows 98 sem modificações.

Resumidamente, os testes e resultados nessa sessão confirmam o desempenho esperado do sistema RMIRep:

- A política de consistência total não é escalável. Quando o número de réplicas no sistema é baixo, o desempenho desta política é uma função linear do número de réplicas e da banda de rede disponível, mas começa a deteriorar à medida que o número de réplicas aumenta;

- O desempenho do protocolo de anti-entropia é uma função linear do número de atualizações propagadas e da banda de rede disponível e portanto é adequado para redes com taxa de transmissão baixa e conectividade intermitente;

- Quase a totalidade do tempo de execução do protocolo de anti-entropia é gasto na rede e no empacotamento, desempacotamento e serialização dos parâmetros;

- A política de criação de novas réplicas de Bayou exerce um grau de importância elevado no desempenho do protocolo de anti-entropia: a maneira como as réplicas Bayou são criadas influencia diretamente no tamanho do vetor de versão e do identificador de cada servidor e portanto determina, em parte, o montante de dados transferidos em cada sessão de anti-entropia;

- O tempo gasto para refazer atualizações desfeitas (rolled back) no protocolo de anti-entropia é praticamente constante com relação ao número de atualizações propagadas;

- O tempo gasto para decidir se uma nova operação deve ser enviada durante o protocolo de anti-entropia é negligenciável; 
- A mudança dinâmica da política de consistência de um grupo de réplicas não é uma operação escalável.

\subsection{A Estrutura e a Organização dos Testes}

Para realizar os testes, foi construído um objeto, TestImpl, que implementa a interface remota Test. Test contém somente um método:

public void doNothing(java.lang.String).

O objeto TestRep foi gerado automaticamente pelo tradutor de classes Repc e foi nesse objeto que os testes foram realizados.

A implementação do método doNothing na classe TestImpl é vazia, para que os resultados obtidos durante os testes reflitam somente questões ligadas à replicação e à consistência dos dados. Também realizamos um teste onde esse método efetuou a multiplicação de dois vetores, para que pudéssemos obter dados mais parecidos com situações do dia-a-dia dos usuários. A razão pela qual doNothing contém um parâmetro String é para que o tamanho das atualizações propagadas pela política de consistência possa ser controlado através do parâmetro. Utilizamos dois tamanhos de atualizações: 1000 e 5000 bytes (B) ${ }^{1}$. Acreditamos que a mensagem de $1000 \mathrm{~B}$ representa bem o tamanho de uma invocação remota típica, enquanto que a mensagem de 5000B representa um caso extremo.

O conteúdo de uma operação propagada é específico à política de consistência utilizada. Na política total, a operação propagada equivale a uma invocação remota do método doNothing. O tempo medido é o intervalo de tempo que TestRep gasta para, após ter executado o método localmente, executá-lo nas demais réplicas. A reconciliação é imediata: o controle retorna ao usuário somente após todas as réplicas terem executado o método. Nenhuma outra operação pode ser executada enquanto doNothing não terminar. O tamanho das atualizações propagadas nessa política é completamente determinado pelo parâmetro String, que é gerado artificialmente: para as mensagens de $1000 \mathrm{~B}$, foram gerados parâmetros de 1000 caracteres; e para mensagens de 5000B, parâmetros de 5000 caracteres $^{2}$.

Na política de consistência Bayou, a operação propagada é a estrutura de dados que encapsula a invocação do método doNothing. O tempo medido é o que TestRep leva para executar uma sessão de anti-entropia com alguma réplica. A reconciliação

\footnotetext{
${ }^{1} \mathrm{O}$ tamanho das atualizaçōes não inclui o cabeçalho das mensagens dos protocolos usados pelo RMI, somente dados no nível de aplicação. Após uma sessão inicial de troca de informação entre as réplicas, o RMI adiciona aproximadamente aproximadamente 50 bytes de sobrecarga a cada mensagem [57].

${ }^{2}$ Todas as plataformas onde realizamos os testes alocam 1 byte para 1 caractere.
} 
das réplicas não é imediata: o controle retorna ao usuário imediatamente após a invocação local do método. O tamanho das atualizações propagadas é determinado pelo parâmetro String e pela estrutura de dados que encapsula doNothing ${ }^{3}$.

O número de réplicas nos experimentos variou entre 2 e 800 . Há aplicações que exigem uma grande número de réplicas de dados, como a sendo desenvolvida pelo projeto SIDAM [17]. Portanto é necessário analisar o desempenho do sistema para um grande número de réplicas de forma a obter conclusões sobre o escalonamento do sistema.

Três plataformas foram usadas nos nossos testes: Windows 98 (uma máquina Pentium II $400 \mathrm{MHz}$ e uma máquina Pentium III $450 \mathrm{MHz}$ ); Linux 2.4 (duas máquinas Pentium II $400 \mathrm{MHz}$ ); e SunOS 5.7 (duas máquinas SPARCStation 4, uma com quatro CPUs de $167 \mathrm{MHz}$ e outra com duas CPUs de $296 \mathrm{MHz}$ ). Todos os Pentiums possuem 128 Mbytes (MB) de memória, enquanto que as SPARCStations possuem 1280 e 512MB respectivamente. As máquinas Windows usam o sistema de arquivos FAT (File Allocation Table) para armazenar os logs das réplicas Bayou, enquanto que as outras usam o NFS. Usamos dois tipos de conexão remota para realizar os testes: uma rede Ethernet de 10Mbps e uma conexão PPP (point-to-point protocol) que se utilizou de um modem com uma taxa de conexão de $9.6 \mathrm{Kbps}$. A taxa real de transmissão não pôde ser medida em nenhum teste. As máquinas Linux e Unix são servidores da rede do IME-USP (Instituto de Matemática e Estatística) e são compartilhadas por estudantes e professores. No entanto, todos os testes foram realizados no período de utilização mínima da rede: em ambos os casos, a CPU estava praticamente $100 \%$ disponível. A maioria das réplicas em cada experimento foram instanciadas em uma mesma máquina. Caso elas estivessem sido distribuídas em máquinas distintas, com uma réplica por máquina, a degradação observada nos experimentos teria sido maior, devido ao tempo gasto pelos protocolos para estabelecer comunicação com as diversas máquinas. Por fim, a maior parte dos testes foi realizada cinco vezes, embora os mais rápidos tenham sido realizados dez vezes e os mais lentos três vezes.

\subsection{Os Tempos de Execução da Política Total}

As figuras 5.1(a) e 5.1(b) mostram os tempos da propagação de 1 método entre duas réplicas com a política total na rede Ethernet. Na plataforma Sun, não conseguimos instanciar mais do que 500 réplicas e na plataforma Windows, não conseguimos instanciar mais do que 700 réplicas e portanto os gráficos mostram resultados incompletos para essas plataformas. Ainda assim, é possível obter algumas conclusões. Como

\footnotetext{
${ }^{3}$ Nos nossos experimentos, o tamanho mínimo dessas estruturas foi de 880B. Portanto, para atualizações de tamanho 1000, foram gerados parâmetros de 120B e para atualizações de tamanho 5000, parâmetros de $4120 \mathrm{~B}$
} 


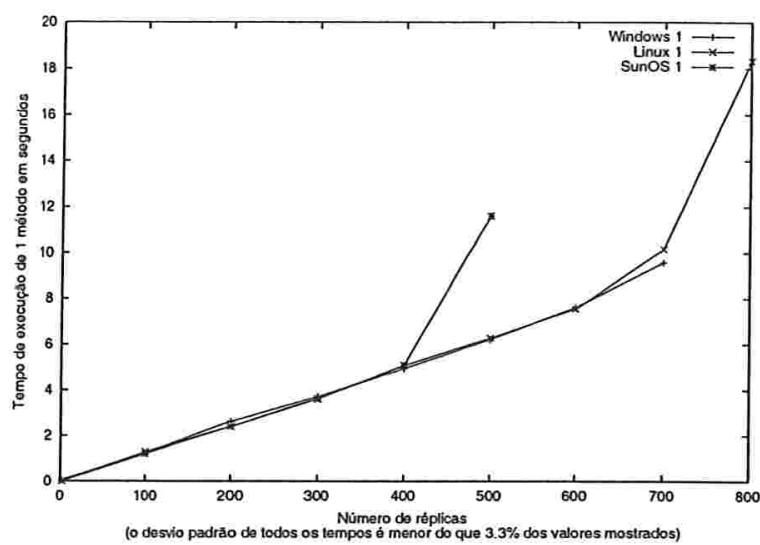

(a) Método de tamanho 1000

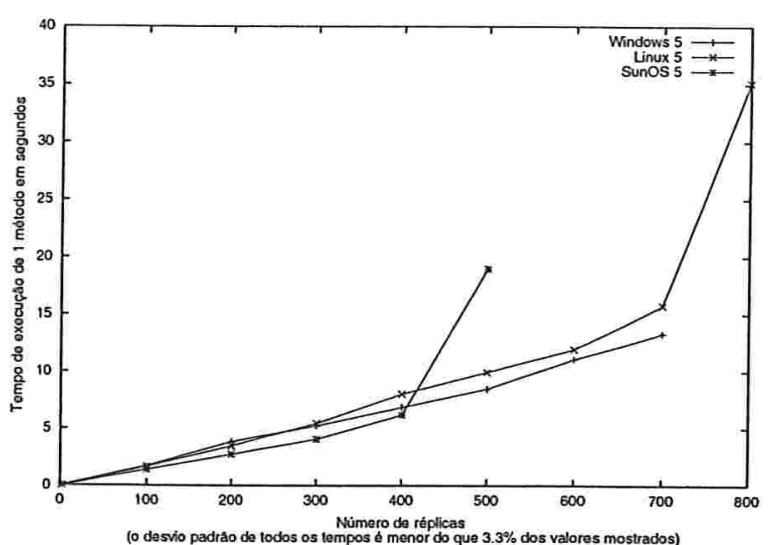

(b) Método de tamanho 5000

Figura 5.1: Execução de 1 método com a política total na rede Ethernet

esperávamos, a política total não é escalável com relação ao número de réplicas. Nos servidores Linux, quando o número de réplicas é pequeno, a política total executa linearmente com relação ao número de réplicas no sistema. Porém, quando esse número ultrapassa 600, o desempenho da política total começa a degradar. Dizemos que 600 é o limite (threshold) do número de réplicas. Nos servidores Sun, embora não tenhamos conseguido instanciar mais do que 500 réplicas, já é possível observar um decréscimo significativo no desempenho do sistema. Na plataforma Windows, não conseguimos detectar uma degradação no desempenho da política total para o número de réplicas instanciadas.

A discordância dos resultados nas plataformas Sun, Linux e Windows pode ser atribuída, em parte, às suas diferentes implementações da máquina virtual Java.

\subsection{Os Tempos de Execução da Política Bayou}

As figuras 5.2(a) e 5.2(b) demonstram que o tempo de execução do protocolo de anti-entropia é uma função linear do número de atualizações sendo propagadas. A inclinação da função depende do tamanho das atualizações e da taxa de transmissão disponível para a reconciliação. Em um extremo, duas máquinas Linux comunicandose via Ethernet requerem, em média, 1,39 segundos para propagarem 100 atualizações. No outro extremo, duas máquinas Windows comunicando-se via modem requerem, em média, 339 segundos (5,6 minutos) para propagarem o mesmo número de atualizações. Esses resultados mostram que o protocolo é adequado para o uso em redes de banda baixa e com conectividade intermitente. 


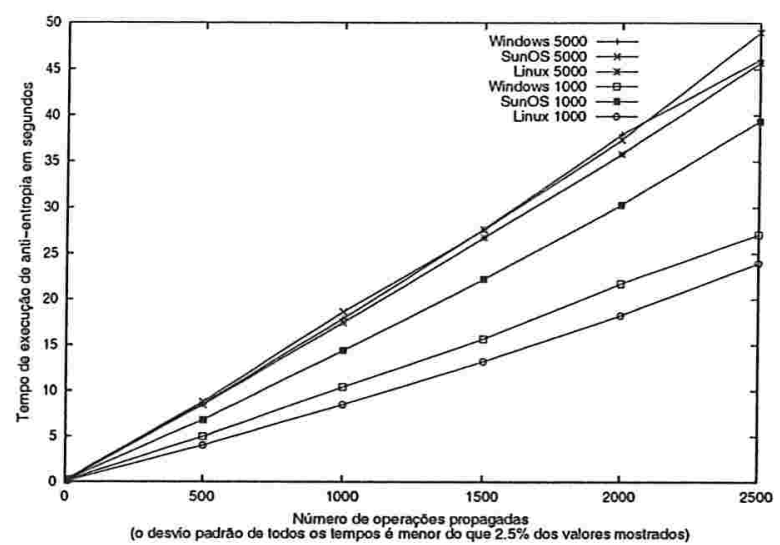

(a) Anti-entropia na Ethernet

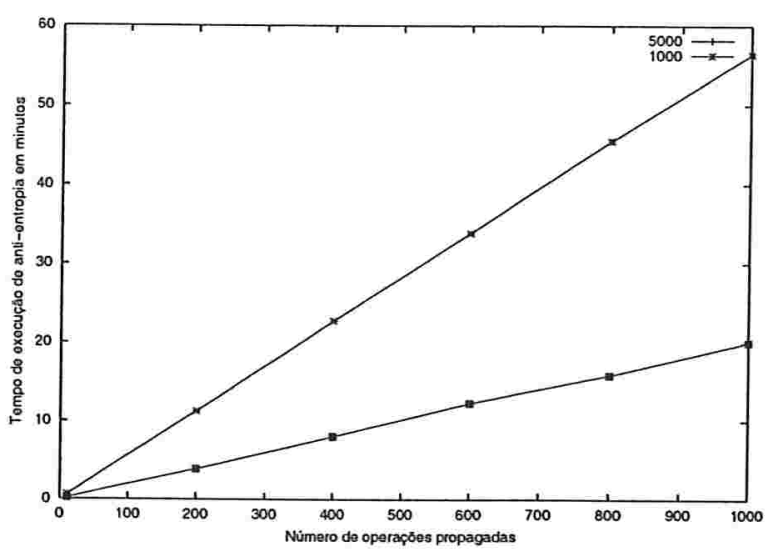

(b) Anti-entropia com PPP

Figura 5.2: Execução de anti-entropia como função do número de réplicas

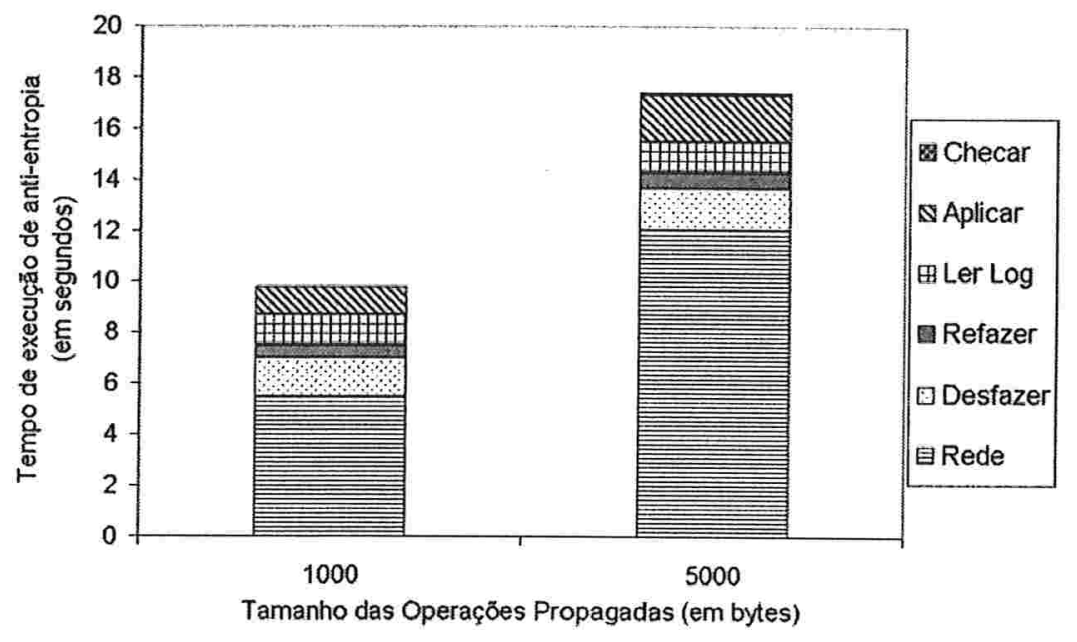

Figura 5.3: Análise do tempo de execução de anti-entropia para 1000 atualizações propagadas na Ethernet com o fator da rede

Para entendermos melhor o desempenho do protocolo, nós analisamos o tempo de execução de sessões de anti-entropia que propagaram 1000 atualizações de tamanho 1000. O gráfico da figura 5.3 corresponde ao tempo de execução do protocolo entre duas máquinas Windows na rede Ethernet. Os testes realizados com o modem mostram que quase $100 \%$ do tempo de execução do protocolo é gasto na rede e por isso os resultados para esses testes não são mostrados.

Como a figura 5.3 mostra, os fatores mais significativos no desempenho do protocolo 


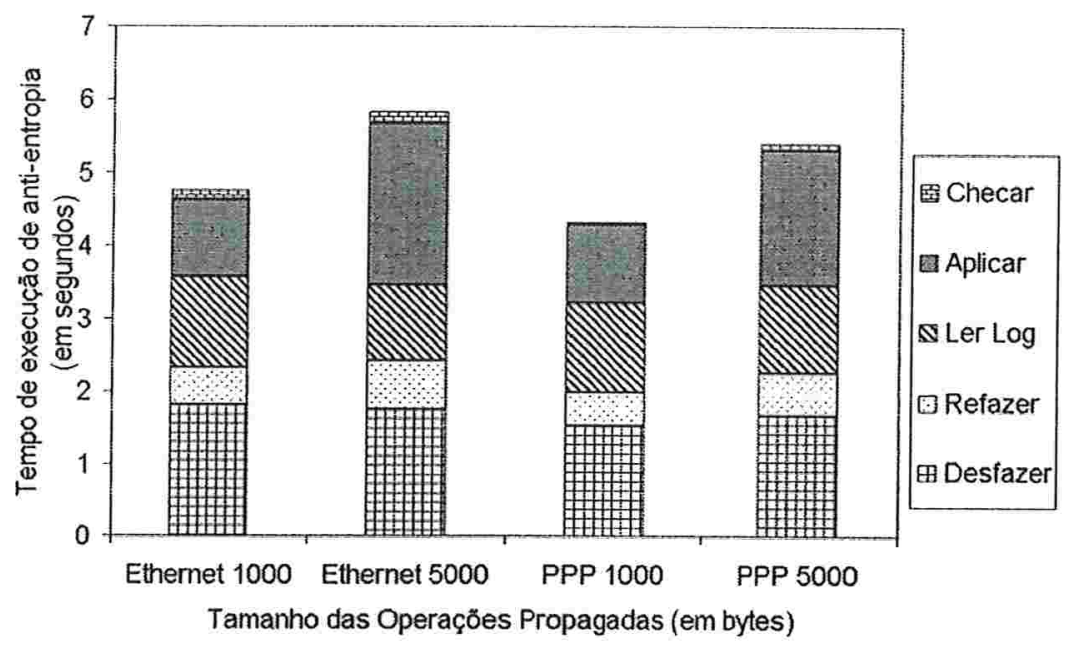

Figura 5.4: Análise do tempo de execução de anti-entropia para 1000 atualizações propagadas na Ethernet e com um modem sem o fator da rede

de anti-entropia são:

- Transferência na rede: essa fase inclui o empacotamento, desempacotamento e serialização dos parâmetros, além do tempo gasto na rede em si. Isso é devido, em parte, às ineficiências nos protocolos de comunicação e serialização usados pelo RMI [53, 54];

- Desfazer as atualizações: o mecanismo que determina se haverá uma reordenação das atualizações lê todo o conteúdo do $\log$ para cada atualização recebida e portanto é lento. Manter todo o contéudo do $\log$ em memória pode não ser possível caso o número de atualizações de uma réplica seja grande. Uma técnica mais viável seria manter somente as atualizações instáveis em estruturas de dados na memória;

- Executar as atualizações: esse estágio corresponde ao tempo que a réplica receptora leva para executar as atualizações recebidas por anti-entropia. Inclusos nessa fase estão o tempo para inserir as atualizações no log da réplica e o tempo de execução dos métodos remotos nos objetos locais. Esse último componente foi nulo nos nossos testes, já que doNothing não efetua nenhuma computação.

- Ler o $\boldsymbol{L o g}$ : esse estágio equivale ao tempo que a réplica remetente leva para ler as atualizações do seu $\log$ e verificar se elas deviam ser enviadas.

Para analisarmos melhor os estágios do protocolo de anti-entropia que levaram tempo menos significativo, a figura 5.4 mostra os tempos de execução do protocolo, 


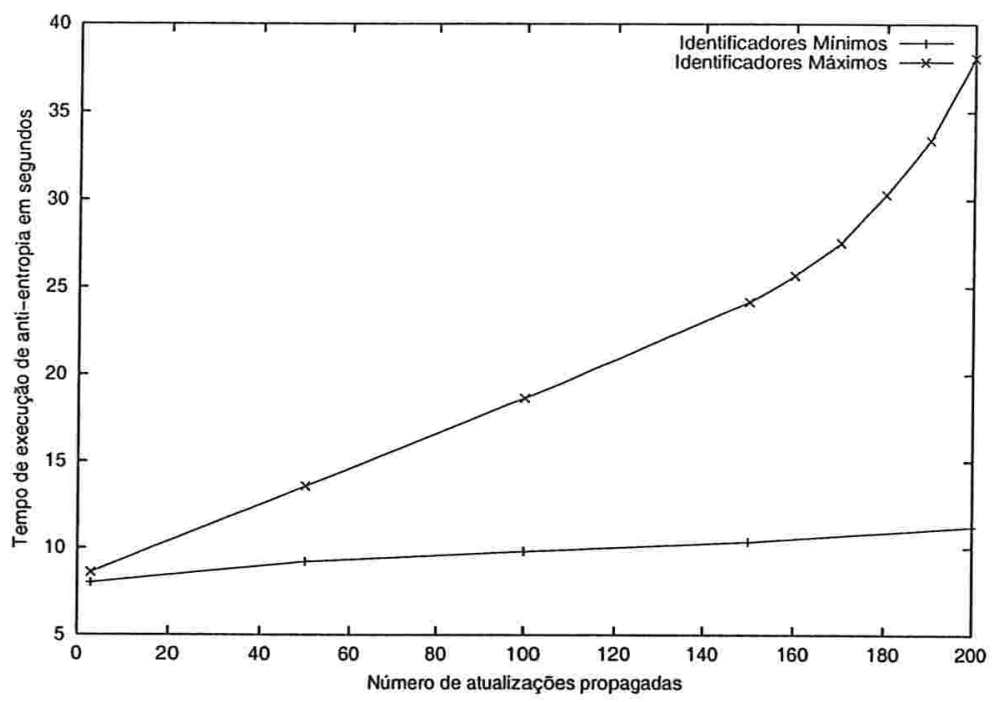

Figura 5.5: Tempo de execução de anti-entropia com réplicas criadas com identificadores máximas

sem levar em consideração o tempo gasto na rede. Os testes foram realizados em máquinas Windows na rede Ethernet e com uma conexão PPP.

O tempo gasto na réplica remetente para decidir se uma atualização devia ser enviada para o receptor foi negligenciável em todos os testes. Também fizemos testes para investigar o tempo que a réplica remetente levaria para decidir se atualizações já conhecidas pelo receptor deveriam ser enviadas. O tempo gasto por uma máquina Linux para ler 1000 atualizações, já conhecidas pelo receptor, foi menor do que 230 milissegundos em todos os casos. Esse teste foi realizado na Ethernet e com a conexão PPP.

Analisamos os efeitos da política de criação de novas réplicas no desempenho do protocolo. A figura 5.5 mostra os resultados de uma sessão de anti-entropia realizada em máquinas Linux na rede Ethernet, onde 1000 atualizações de tamanho 1000 foram propagadas. A figura mostra que o protocolo é linear com relação ao número de réplicas no sistema quando todas as réplicas são criadas de um mesmo servidor, enquanto que seu desempenho modela uma função quadrática quando as réplicas são criadas linearmente. E interessante notar, neste último caso, que o protocolo só começa a deteriorar após 150 réplicas serem instanciadas.

Medimos o tamanho das três estruturas do objeto Bayou0bject que causam a queda de desempenho do protocolo nesse último caso: os dois vetores de versão e o identificador do servidor que criou o ORR. Em ambos os testes essas estruturas de dados apresentam o mesmo tamanho na primeira réplica do sistema: 343B para cada vetor de 


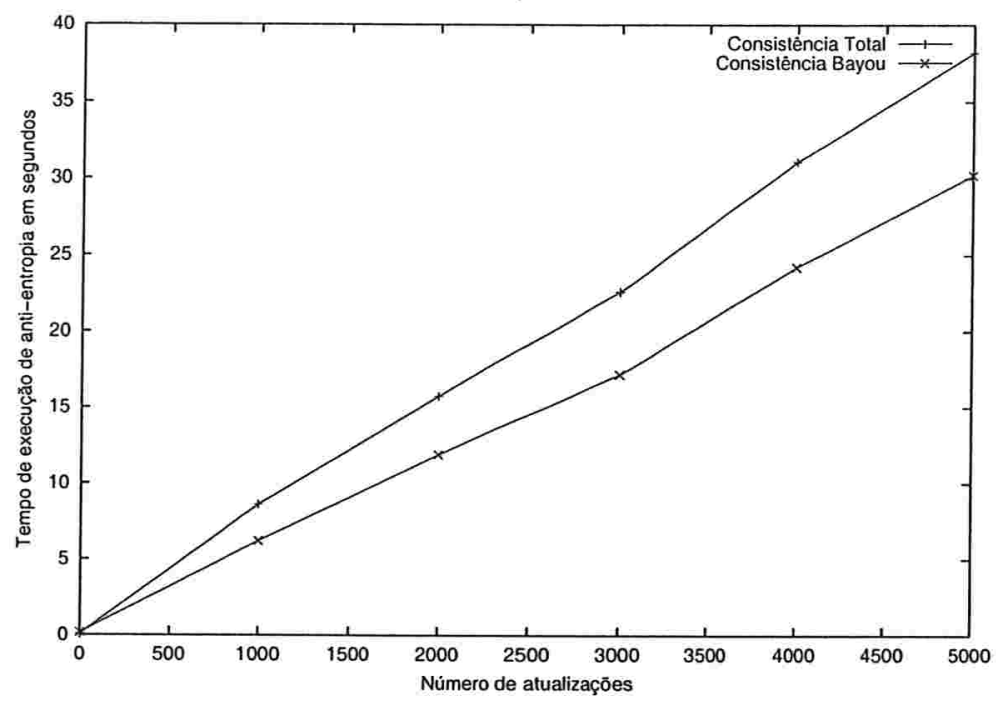

Figura 5.6: Comparação entre o desempenho das políticas total e Bayou como função do número de atualizações propagadas

versão e 104B para o identificador do servidor. A última réplica criada (número 200) no primeiro teste aloca 5,6 Kbytes (KB) para cada vetor de versão e 104B para o identificador do servidor, enquanto que essa mesma réplica no segundo teste aloca $279,6 \mathrm{~KB}$ para cada vetor de versão e $2,8 \mathrm{~KB}$ para o identificador do servidor. Isso corresponde a uma diferença superior a meio megabyte entre os dois testes, o que nos leva a concluir que a política de criação de réplicas deve ser cuidadosamente escolhida. Uma possível política seria estabelecer uma política que imponha um limite no tamanho máximo da cadeia linear de servidores, criando assim uma topologia de árvore onde o comprimento máximo da raiz até qualquer uma das suas folhas é determinado pelo usuário.

\subsection{Comparação entre as Políticas Total e Bayou}

Ao comparar as políticas de consistência total e Bayou, nós desejamos determinar sob quais circunstâncias a política Bayou obtém um desempenho superior ao da política total. Para realizarmos essa comparação, não consideramos as vantagens e as desvantagens de cada política com relação à disponibilidade e à consistência dos dados. A nossa análise leva em consideração puramente os gastos de cada política para efetuar a reconciliação de réplicas divergentes.

Em nossos testes, um par de réplicas Bayou realizou anti-entropia variando o número de atualizações enviadas. Um outro par de réplicas com consistência total propagou o mesmo número de métodos. A figura 5.6 apresenta os resultados dessa comparação. 
As réplicas executaram no sistema Windows e se comunicaram através de uma conexão PPP.

O eixo $x$ representa o número de atualizações propagadas. $\mathrm{O}$ eixo $y$ mostra o tempo que cada política levou para enviá-las à réplica remota. Na política total, cada invocação local de um método desencadeou o envio de uma atualização. Na política Bayou, configuramos a política de usuário whenPolicy para desencadear uma sessão de anti-entropia após um número de invocações locais ocorrerem. O limite de variação de consistência (sessão 4.7.8) foi igual ao número de atualizações propagadas. Por exemplo, quando 100 atualizações foram enviadas, uma sessão de anti-entropia ocorreu após a centésima atualização ser realizada.

Podemos observar que somente quando o limite de variação de consistência é igual a um (ou seja, cada invocação de um método desencadeia uma sessão de anti-entropia) a política total tem um desempenho superior ao de Bayou. Isso é esperado: enquanto que a atualização propagada pela política total corresponde a uma invocação remota, Bayou propaga uma estrutura de dados bem maior (sessão 5.1). Quando o limite de variação de consistência é superior a 10, o desempenho de Bayou já se mostra superior ao da total. Isso se deve, em grande parte, ao fato de que a política total deve tomar posse de um lock remoto para cada invocação local, triplicando assim o seu número total de invocações remotas.

Por fim, podemos concluir que o tempo médio gasto para propagar uma atualização na política Bayou independe do limite de variança. Para um limite de 10, a propagação de uma atualização levou, em média, 3,8 segundos. Para um limite de 1000, esse tempo foi de 3,9 segundos. Isso confirma o desempenho linear do protocolo e nos permite concluir que a periodicidade das sessões de anti-entropia não influi no desempenho do sistema. Portanto, réplicas podem ser mantidas altamente consistentes de maneira eficiente. No entanto, na implementação atual de Bayou, as operações realizadas por clientes são bloqueadas se a réplica correspondente estiver realizando uma sessão de anti-entropia com outra réplica. Como discutido na sessão 4.7.4, esse problema pode ser solucionado com um projeto cuidadoso de sincronização das estruturas de dados da política Bayou.

\subsection{Mudança Dinâmica da Política de Consistência}

O desempenho do mecanismo de mudança da política de consistência é uma função do número de réplicas no sistema e da nova política de consistência. A figura 5.7 mostra que o tempo gasto para mudar a política de réplicas Bayou para a consistência total é uma função linear ${ }^{4}$. Por outro lado, a transição da política total para Bayou leva mais

\footnotetext{
${ }^{4}$ Essa afirmação é válida para um número pequeno de réplicas. Esperamos que, quando esse número aumentar, o desempenho da mudança de política sofrerá uma degradação similar à observada nos gráficos
} 


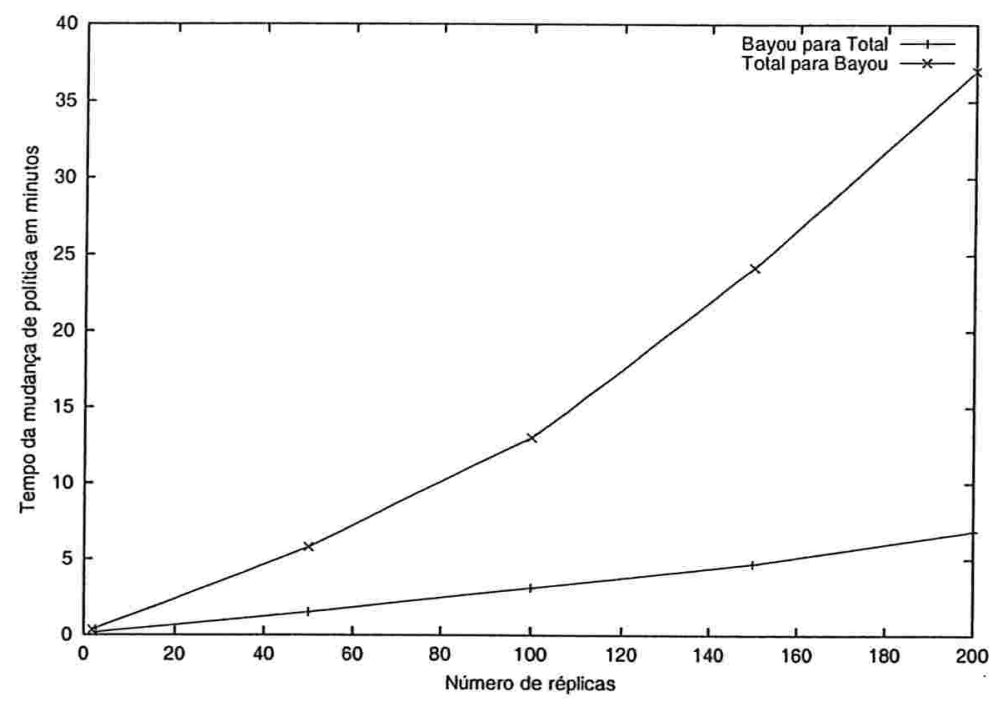

Figura 5.7: Tempo de mudança dinâmica da política de consistência com uma conexão PPP

tempo. Os dados obtidos para os mesmos experimentos na rede Ethernet apresentam dados similares, porém na escala de segundos.

A razão pela qual a transição da política total para Bayou não é uma operação linear é previsível já que, nesse caso, é necessária uma transferência completa do estado da réplica que desencadeou a mudança, possivelmente envolvendo grande quantidade de dados.

5.1 (a) e 5.1(b) na página 64. 


\section{Capítulo 6}

\section{Trabalhos Relacionados}

Um grande número de projetos de pesquisa têm utilizado consistência fraca para reconciliar os seus dados relaxadamente. Nesse capítulo apresentamos três sistemas que fornecem funcionalidade similar à do Bayou e realizamos breves análises desses projetos. Investigamos o ambiente para o desenvolvimento de objetos distribuídos Rover, o sistema de arquivos Coda e o ambiente de objetos replicados Deno. Concluímos esse capítulo com uma breve descrição de alguns outros trabalhos relacionados. As seções 6.1 e 6.2 contém, em parte, material adaptado de [67].

\subsection{Rover}

Rover [37,38] é um kit para o desenvolvimento de objetos distribuídos para aplicações móveis. Rover fornece ferramentas e abstrações de comunicação para o desenvolvimento de aplicações móveis transparentes (mobile-unaware) e não-transparentes (mobile-aware).

\subsubsection{Arquitetura do Sistema}

Há dois conceitos chaves na arquitetura de Rover: chamadas remotas de procedimento alinháveis (queued remote procedure calls, QRPCs), que permitem chamadas assíncronas a objetos remotos e objetos dinâmicos reendereçáveis (relocatable dynamic objects, RDOs), que permitem a transferência de objetos do servidor para o cliente e vice-versa. Tanto o código como os dados de uma aplicação Rover são representados como RDOs. QRPC é uma variação do modelo de RPC tradicional: quando um cliente realiza uma operação local, ela é armazenada em um log e o controle retorna imediatamente ao cliente. As operações são propagadas quando houver uma conexão com a rede, possivelmente em lote. 


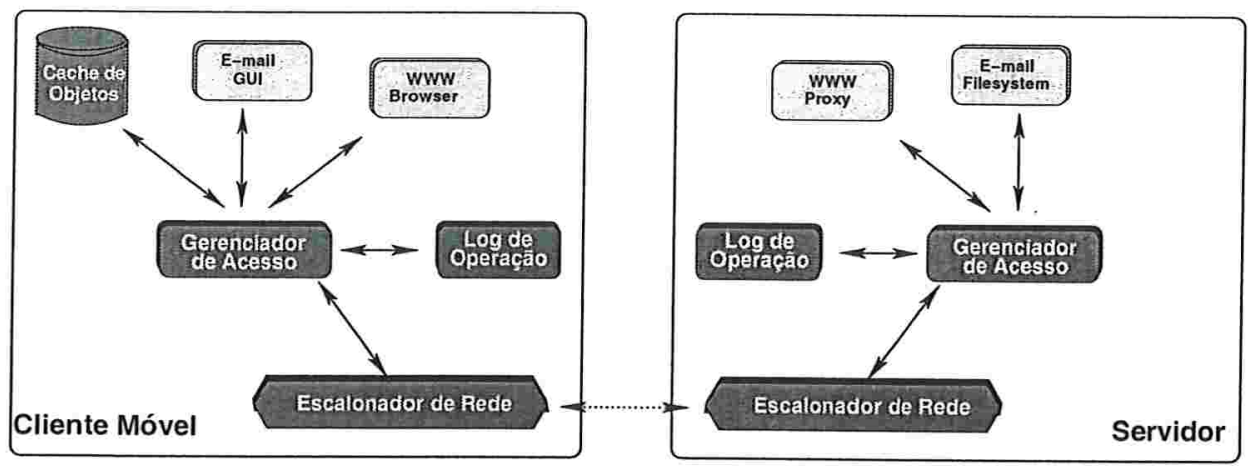

Figura 6.1: A arquitetura de Rover [38]

O programador deve distribuir a funcionalidade da aplicação entre o cliente e o servidor. A aplicação trabalha junto ao ambiente de execução do Rover para importar RDOs de servidores para o cache do cliente, realizando operações locais nesses objetos e propagando essas operações para o servidor relaxadamente.

O ambiente de execução do Rover é composto por quatro componentes principais, como mostra a figura 6.1: o gerenciador de acesso (access manager), o cache de objetos (presente somente no cliente), o log de operações e o escalonador de rede. O gerenciador de acesso é responsável por todas as interações entre o cliente e o servidor, atendendo a requisições por RDOs, gerenciando o $\log$ do cliente e mediando o acesso à rede. Os clientes se comunicam com os servidores através de QRPCs e podem requisitar réplicas de objetos remotos. Por fim, o escalonador de rede é responsável por propagar ao servidor os QRPCs presentes no seu log relaxadamente.

\subsubsection{Operação Desconectada}

Em preparação para desconexões voluntárias, o cliente deve transferir RDOs de interesse para o seu cache. A interface para a escolha de RDOs é específica à aplicação usuária.

A principal política de consistência do Rover é baseada em uma cópia primária. Todo RDO possui um servidor mãe, que é responsável por reconciliar as atualizações feitas às réplicas do seu objeto. Clientes importam cópias do RDO desse servidor para seus caches e exportam QRPCs que contém as atualizações realizadas na sua réplica de volta ao servidor mãe. Rover permite que outros protocolos de consistência sejam definidos, para atender às necessidades específicas de aplicações variadas.

Quando um cliente está desconectado, requisições por RDOs que não estejam presentes no seu cache são inseridas no log na forma de QRPCs. Quando o cliente executa invocações que modificam o estado de RDOs no seu cache, Rover insere um QRPC no 
$\log$, executa a invocação localmente e retorna o controle à aplicação.

Quando o cliente se reconecta, QRPCs são propagados relaxadamente aos servidores mãe dos RDOs modificados. As invocações são executadas nesses servidores e conflitos são detectados e resolvidos de acordo com rotinas especificadas pela aplicação usuária. Métodos read-only são processados localmente e não precisam ser propagados ao servidor.

\subsubsection{Conectividade Fraca}

O protocolo de reconciliação de Rover é incremental e por isso se adequa a ambientes de rede com conectividade fraca. Várias otimizações no processo de transferência de operações são possíveis, entre elas o envio em lotes de atualizações para um mesmo servidor e a reordenação de operações de modo a favorecer as mais urgentes. Também é esperado que aplicações se envolvam no processo de otimização da transferência de dados. Um RDO, por exemplo, pode definir métodos para a compressão e descompressão de dados, diminuindo assim a quantidade total dos dados transferidos.

\subsubsection{Comparação entre Bayou e Rover}

Rover permite que várias políticas de consistência sejam implementadas e possibilita às aplicações usuárias uma participação ativa na configuração de parâmetros de baixo nível quanto à propagação dos dados entre o cliente e o servidor. No entanto, a implementação desses mecanismos adiciona à complexidade das suas aplicações, requerendo uma média de 10 a $15 \%$ de código extra [38]. Bayou fornece um mecanismo similar através da configuração das políticas de usuário, que concentram a funcionalidade da replicação e da consistência dos dados no sistema. No entanto, assim como em Rover, métodos para a deteç̧ão e resolução automáticas de conflitos devem ser fornecidos pela aplicação usuária.

\subsection{Coda}

Coda [45] é uma sistema de arquivos replicados altamente disponível, projetado para dar suporte transparente à replicação de dados. Coda utiliza o sistema de arquivos Unix para armazenar seus arquivos. 


\subsubsection{Arquitetura do Sistema}

Coda é composto por um número de clientes e um número bem menor de servidores, localizados em uma rede fixa. Conjuntos de arquivos, denominados volumes, podem ser replicados nos servidores e são mantidos consistentes de acordo com os critérios de one-copy-serializability [71]. Clientes mantém cópias de arquivos em caches locais para aumentar a disponibilidade dos dados. Há uma distinção entre a qualidade das réplicas localizadas nos servidores (denominadas cópias de primeira classe) e das réplicas presentes nos clientes (denominadas cópias de segunda classe), que são mais incompletas, inexatas e menos persistentes. Coda possui um gerenciador de cache, Vênus, que durante a desconexão de um cliente age como um pseudo-servidor.

\subsubsection{Operação Desconectada}

Para dar suporte a desconexões, Vênus possui três estados de execução: acúmulo (hoarding), emulação e reintegração. Durante o período de acúmulo Vênus se comunica com algum servidor para atender às requisições do cliente, mas procura manter arquivos de interesse no seu cache, prevendo uma possível desconexão. O protocolo de consistência do cache é baseado em callbacks: clientes são notificados pelos servidores quando arquivos presentes no seu cache são modificados por outros processos.

Ao se desconectar, Vênus entra no estado de emulação. Nessa fase Vênus funciona como um pseudo-servidor e atende às requisições do cliente baseado no conteúdo do seu cache. Alterações feitas nos arquivos são armazenadas em logs e requisições a objetos não presentes no cache geram erros na aplicação.

Ao se reconectar, Vênus muda para o estado de reintegração. Nessa fase, o conteúdo do cache do cliente é reconciliado com os servidores. Conflitos são resolvidos com o auxílio de programas implementados pela aplicação usuária (Application Specific Resolvers, ASRs).

Vênus se utiliza de informações implícitas e explícitas para decidir quais arquivos ele deve manter no cache durante a fase de acúmulo. A informação implícita é baseada no histórico recente da utilização de arquivos no cliente, enquanto que a informação explícita é obtida com o auxílio das aplicações usuárias que determinam, por meio de uma estrutura denominada hoarding database [45], os arquivos que são de interesse para o usuário.

\subsubsection{Conectividade Fraca}

Vênus funciona de maneira diferente quando conectado intermitentemente a um servidor. Atualizações feitas em arquivos presentes no cache de um cliente são propa- 
gadas assincronamente por meio de um mecanismo de envelhecimento e de uma técnica denominada reintegração de gotas (trickle reintegration). Coda permite que a granularidade dos dados propagados seja definida para evitar um estrangulamento nos meios de comunicação.

O protocolo de consistência do cache de um cliente, quando a conexão entre clientes e servidores possui taxa de transmissão baixa, não é mais baseado em callbacks e sim no mecanismo de revalidação [59]. Coda utiliza diferentes níveis de granularidade [45] para reduzir o tempo de revalidação de caches em ambientes com largura de banda limitada.

\subsubsection{Comparação entre Bayou e Coda}

Coda organiza suas réplicas em uma hierarquia de clientes e servidores e impossibilita a comunicação entre réplicas remotas sem que haja a intervenção de um servidor. Bayou, por sua vez, permite a comunicação entre qualquer par de réplicas disponíveis. Uma das vantagens de utilizar uma topologia mais restritiva, como a de Coda, é que um cliente pode manter uma estimativa melhor da qualidade dos dados da réplica com a qual ele está se comunicando.

Coda foi originalmente projetado para dar suporte à replicação transparente de dados. ASRs foram adicionados à sua arquitetura posteriormente, para permitir que atualizações conflitantes pudessem ser resolvidas de maneira específica à aplicação. ASRs definem funcionalidade equivalente aos procedimentos check e merge do Bayou.

\subsection{Deno}

Deno $[41,42]$ é um sistema de objetos replicados projetado para ambientes móveis. Deno se baseia no modelo de sistema do Bayou e apresenta muitas características similares a ele, como suporte para a comunicação ponto-a-ponto entre réplicas, propagação de atualizações via anti-entropia e resolução automática de conflitos. A principal caracterítisca de Deno que o difere de Bayou é o seu mecanismo de estabilização de atualizações, que funciona através de eleições e de valores de circulação (currency).

\subsubsection{Procedimentos de Comutatividade}

Procedimentos de comutatividade se baseiam no fato de que muitas operações em sistemas de informação em redes de grande acesso são comutativas, ou seja, não precisam obedecer a uma ordem global de serialização. Dessa maneira, atualizações podem ser ordenadas de maneira diferente em réplicas distintas sem alterar a consistência dos 
dados. Deno permite que aplicações usuárias definam tabelas de comutatividade, listando operações que são comutáveis entre si. A ausência de uma operação nessa tabela indica que ela não é comutável com nenhuma outra operação. Ao processar uma atualização $a$, cujo identificador é menor do que o de alguma atualização $b$ presente no $\log$ de um servidor, Deno verifica se $a$ e $b$ são comutáveis, usando a tabela de comutatividade. Se elas forem comutáveis, $a$ pode ser inserida no $\log$ depois de $b$ sem que seja necessário reordenar as atualizações existentes.

\subsubsection{Estabilização de Atualizações}

Deno utiliza um mecanismo de eleição para estabilizar atualizações. Ao contrário de protocolos que exigem a participação da maioria das réplicas de um grupo [15], o protocolo de eleição de Deno propaga votos através de sessões de anti-entropia entre pares de réplicas e não exige que mais do que dois servidores estejam simultaneamente conectados.

Cada objeto possui um valor de circulação fixo ${ }^{1}, 1.0$, distribuído entre as suas réplicas. Quando uma réplica $o_{n}$ é criada da réplica $o_{n-1}$, o valor de circulação de $o_{n-1}$ é dividido entre as réplicas $o_{n}$ e $o_{n-1}$, de acordo com uma política definida pela aplicação usuária. À medida que uma atualização é propagada, as réplicas que a aceitam "votam" nessa atualização. Os votos de réplicas distintas possuem pesos diferentes e são equivalentes ao valor de circulação de uma réplica. A atualização carrega consigo os votos de todas as réplicas que votaram nela. Uma atualização pode ser estabilizada, por qualquer réplica, em duas situações:

1. Quando o valor total dos votos recebidos por essa atualização for maior do que 0.5 ;

2. Em caso de atualizações conflitantes, quando nenhuma outra atualização puder ganhar mais votos e a atualização em questão for escolhida por um procedimento de desempate, que leva em conta o identificador do servidor que gerou a atualização.

A figura 6.2 demontra o processo de estabilização de atualizações de Deno. Quatro servidores possuem uma réplica dos objetos $x$ e $y$. O valor de circulação desse objetos é dividido igualmente entre os servidores. Em 6.2(a), o servidor $v_{1}$ cria uma atualização instável para $x$ em $t_{0}$. Em $t_{1}, v_{1}$ propaga essa atualização para $v_{2}$ e $v_{2}$ a envia para $v_{3}$ em $t_{2}$. Nesse instante, $v_{3}$ estabiliza a atualização $u_{1,1}$, pois ela já possui $75 \%$ do valor de circulação do objeto $x$. No momento $t_{3}, v_{2}$ também a estabiliza e $v_{4}$ cria uma atualização, $u_{4,2}$, que será abortada quando $v_{4}$ ganhar conhecimento de $u_{1,1}$.

\footnotetext{
${ }^{1}$ Esse valor pode mudar durante falhas no servidor onde o objeto replicado reside.
} 


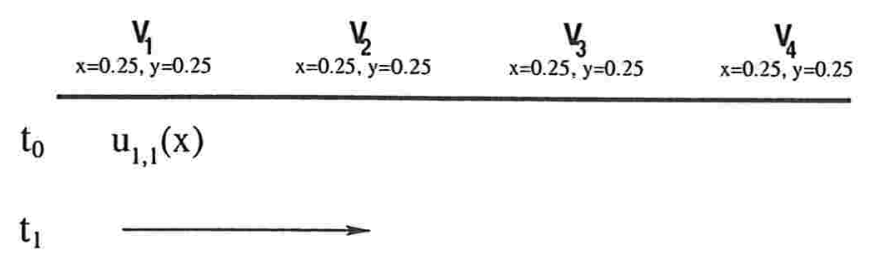

(a) $t_{2}$
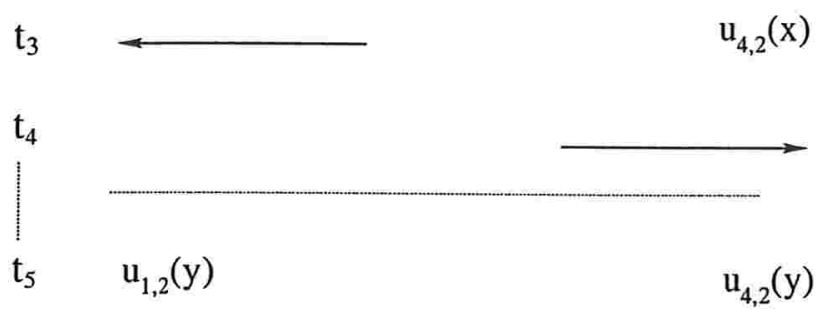

(b) $t_{6}$

$\mathrm{t}_{7}$

$? ?$

Figura 6.2: Estabilização de atualizações através de valores de circulação

A figura 6.2(b) mostra duas atualizações conflitantes, $u_{1,2}$ e $u_{4,2}$, criadas no momento $t_{5}$ em $v_{1}$ e em $v_{4}$, respectivamente. Em $t_{6} v_{1}$ propaga $u_{1,2}$ para $v_{2}$ e $v_{4}$ envia $u_{4,2}$ para $v_{3}$. Nesse momento, tanto $u_{1,2}$ como $u_{4,2}$ estão empatadas, cada uma com $50 \%$ dos votos. Deno desempata as atualizações usando os identificadores dos servidores e, nesse caso, a atualização $u_{1,2}$ ganha a eleição e $u_{4,2}$ é abortada.

\subsubsection{Alocação do Valor de Circulação}

A política através da qual valores de circulação são atribuídos a novas réplicas pode ser configurada por aplicações usuárias. Dividir o valor de circulação igualmente entre as réplicas ${ }^{2}$ simula um mecanismo de eleição tradicional [15], enquanto que concentrar todo o valor de circulação de um objeto em um servidor simula o mecanismo de uma réplica primária [72].

\subsubsection{Comparação entre Bayou e Deno}

O modelo de sistema de Deno se assemelha em grande parte ao de Bayou e portanto os dois sistemas compartilham muitas propriedades e objetivos, incluindo suporte para

\footnotetext{
${ }^{2} \mathrm{~A}$ não ser que o número de réplicas de um objeto seja conhecido a priori, dividir o valor de circulação de um objeto igualmente entre réplicas não é uma tarefa simples.
} 
redes de alta latência e conectividade intermitente. A tabela de comutatividade de Deno pode ser estendida para exercer função semelhante aos procedimentos check e merge do Bayou, permitindo a resolução automática de conflitos específicos à aplicação usuária.

O protocolo de estabilização de atualizações de Deno oferece maior flexibilidade do que o mecanismo utilizado por Bayou, já que Deno pode ser configurado dinamicamente para simular o funcionamento de uma réplica primária. No entanto, resultados experimentais [41] demonstram que, até mesmo em ambientes de alta latência, o mecanismo de réplicas primárias estabiliza atualizações mais rapidamente.

\subsection{Outros sistemas}

Nessa sessão apresentamos brevemente outros trabalhos relacionados com a nossa linha de pesquisa.

Krishnaswamy et. al. [46] implementaram um sistema que provê caching de objetos remotos Java. Invocações que não modificam o estado de uma réplica são executadas localmente, enquanto que métodos que alterem o seu estado devem ser sincronizados com a réplica primária desse objeto. Dessa maneira, esse sistema provê um protocolo de consistência que se assemelha à política total do RMIRep. O projeto inicial do RMIRep se baseou, em grande parte, na arquitetura desse sistema.

Rumor [29] é um sistema de arquivos baseado no sistema Ficus [30] e foi projetado para uso em redes de computadores móveis. Rumor propaga suas operações entre pares de réplicas e portanto não exige que mais do que dois servidores estejam conectados simultaneamente. Rumor provê mecanismos para a deteç̧ão de conflitos, porém aplicações que desejem resolvê-los automaticamente devem implementar suas próprias ferramentas e incorporá-las ao sistema.

Rumor utiliza uma topologia adaptável de anéis, que se reconfigura à medida que novas réplicas são adicionadas ou quando há desconexões ou falhas nos servidores. Embora detalhes do protocolo de reconfiguração do Rumor não estejam presentes em [29], esse tipo de mecanismo exige que cada servidor tenha conhecimento das demais réplicas do sistema para que, em casos extremos onde somente um par de réplica esteja disponível, a reconciliação de dados ainda possa ser possível.

O projeto TACT [80] propõe um conjunto de métricas para limitar a inconsistência máxima entre servidores replicados com consistência fraca. TACT define três métricas: erro númerico, erro de ordem e obsolescência. Erro númerico impõe um limite ao número de atualizações que uma réplica pode executar sem reconciliar seus dados com outra réplica. Ordem de erro limita o número de atualizações instáveis presentes em uma réplica e obsolescência impõe um limite de tempo real entre a execução de uma 
atualização em um servidor e a sua propagação a outros servidores. Bayou permite que aplicações usuárias controlem, de maneira limitada, a inconsistência máxima entre réplicas do sistema, através da configuração das políticas de usuário. Em particular, a política MethodCount (sessão 4.7.8) equivale à métrica de erro numérico do Rumor.

Wiesmann et al. [77] investigam mecanismos de replicação usados em sistemas distribuídos e em bancos de dados e propõem um modelo que permite que diferentes algoritmos e técnicas de replicação de ambas as comunidades possam ser comparados. De acordo com esse trabalho, aplicações de sistemas distribuídos geralmente possuem a noção de um grupo, que fornece o paradigma de comunicação um-para-muitos (oneto-many). RMIRep implementa a noção de grupo, mas de forma limitada. Embora cada réplica possua conhecimento das demais réplicas, o conceito de líder é inexistente e o sistema não fornece suporte para broadcasts atômicos e totalmente ordenados.

Um trabalho recente desenvolvido no Instituto Federal de Tecnologia da Suíça [23] propõe uma técnica de replicação ativa de objetos, onde ações de consistência são enviadas pelo cliente a todas as réplicas [77]. Replicação ativa geralmente é implementada usando broadcasts atômicos. Esse trabalho difere de outros projetos porque apresenta um algoritmo que é eficiente na maioria dos casos e que simultaneamente previne inconsistências nos estados das réplicas.

Por fim, sistemas como Bayou, Rover e Coda só permitem atualizações realizadas em um único objeto por vez. Holliday et al. [31] apresentam protocolos que integram o modelo de propagação epidêmica de atualizações [20] a quóruns de réplicas, de modo a dar suporte a atualizações realizadas em múltiplos objetos. O mecanismo de estabilização de atualizações de Deno se baseia, em grande parte, nesse projeto. 


\section{Capítulo 7}

\section{Conclusão}

Ambientes de computação móveis apresentam desafios e restrições de comunicação e integridade de dados que não estão presentes em sistemas distribuídos tradicionais. Embora infra-estruturas que suportem ambientes de computadores móveis estejam se tornando cada vez mais populares, a replicação de dados é uma técnica inestimável em redes de alta latência. Em particular, problemas introduzidos com o advento de redes e computadores móveis não podem ser solucionados somente com conexões rápidas e precisam ser cuidadosa e diretamente tratados por ambientes específicos.

Mecanismos de replicação e consistência fraca propiciam alta disponibilidade de dados e controle sobre parâmetros de baixo nível que dizem respeito à reconciliação dos dados. Essas políticas são ideais para o uso em sistemas de computadores móveis, onde há grande heterogeneidade de plataformas e tipos de rede. No entanto, esses sistemas freqüentemente introduzem inconsistências no estado da informação replicada e necessitam reconciliar seus dados junto a outras réplicas de maneira eficiente.

Nessa dissertação estudamos várias políticas de consistência fraca, com ênfase na política Bayou $[5,64,74]$, desenvolvida no Xerox PARC. Bayou permite que aplicações controlem o equilíbrio entre os graus de disponibilidade, inconsistência e reconciliação de dados, através do mecanismo das políticas de usuário, que podem ser configuradas para aplicações específicas. Atestamos o fato de que fornecer uma interface para a configuração dessas políticas é um processo simples e intuitivo.

Implementamos a política Bayou junto com a política de consistência total e de réplicas independentes no sistema RMIRep, um ambiente de replicação semitransparente que estende o sistema Java RMI [57, 76, 78]. RMIRep fornece suporte para a mudança dinâmica da política de consistência de um objeto replicado, podendo portanto ser usado em um amplo espectro de aplicações. Em particular, RMIRep pode ser usado em sistemas de informação dinâmicos que precisam variar o grau de consistência entre suas réplicas e impõem limites no desempenho da reconciliação dos 
seus dados. Um exemplo de uma aplicação onde o RMIRep seria útil é o SIDAM [17].

Apresentamos um breve histórico do mecanismo de chamada remota de procedimentos (RPC, $[10,60])$ e investigamos o sistema Java RMI e a sua contextualização na literatura.

Experimentamos com a política Bayou e observamos que o seu desempenho é linear com relação ao número de atualizações transmitidas e à banda de rede disponível. Isso torna Bayou uma política adequada e viável para uso em redes com taxa de transmissão baixa e com conectividade intermitente.

O projeto inicial do RMIRep tentou adicionar a funcionalidade da replicação e da consistência dos dados à camada de referência remota do Java RMI. No entanto, decidimos seguir outra abordagem porque Java RMI não permite que algumas constantes importantes sejam redefinidas por outras classes. O projeto final do RMIRep incorporou os módulos de replicação e consistência no nível da camada de aplicação. Isso possibilitou um aumento na modularidade, extensibilidade e simplicidade do nosso código, à custa de um possível detrimento no desempenho do sistema.

Uma contribuição dessa dissertação foi a integração de políticas de consistência diversas em um sistema de replicação que se baseia em uma tecnologia popular e extensível, o Java RMI. Embora muitas políticas venham sendo propostas e implementadas em sistemas específicos ou pouco conhecidos, é de grande proveito integrar algumas delas em um sistema popular, que possa co-existir com aplicações de sistemas de informação existentes.

Uma outra contribuição foi o desenvolvimento de um sistema que pode servir como arcabouço para o desenvolvimento e a análise de outras políticas de consistência, o RMIRep. Embora a sua implementação atual não forneça suporte para operações atômicas e objetos persistentes, RMIRep implementa funcionalidade suficiente para dar suporte a um vasto número de mecanismos de consistência.

Futuramente, algumas melhorias podem ser feitas no sistema RMIRep, para permitir a tradução de um objeto remoto que implemente várias interfaces remotas. Atualmente, RMIRep só oferece suporte para objetos remotos que implementem uma única interface remota. Uma outra melhoria seria o desenvolvimento de interfaces padronizadas para que novas políticas de consistência possam ser integradas e usadas por um objeto remoto sem que seja necessário modificar o código fonte desse objeto.

Uma outra linha de trabalhos futuros envolvendo políticas de consistência seria um estudo de políticas de usuário ótimas para ambientes de rede específicos. Nesse estudo seria considerado quais as melhores políticas de usuário para um determinado ambiente de rede. Além disso, poderia ser implementado um mecanismo que trocasse as políticas de usuário automaticamente quando fossem detectadas mudanças no ambiente de rede de uma determinada réplica. 
O código de RMIRep encontra-se na página www.ime.usp.br/〜 jorgeb/reprmi. 


\section{Apêndice A}

\section{Definição das Interfaces da Política de Consistência Bayou}

\section{A.1 Interface BayouClientInterface}

\begin{tabular}{|c|l|}
\hline void & $\begin{array}{l}\text { antiEntropy() } \\
\text { Start an anti-entropy session. }\end{array}$ \\
\hline int & $\begin{array}{l}\text { getTruncateLogPolicy() } \\
\text { Get the value of truncateLogPolicy. }\end{array}$ \\
\hline void & $\begin{array}{l}\text { setTruncateLogPolicy (int policy) } \\
\text { Set the value of truncateLogPolicy. }\end{array}$ \\
\hline int & $\begin{array}{l}\text { getDelay() } \\
\text { Get the delay between anti-entropy sessions. }\end{array}$ \\
\hline void & $\begin{array}{l}\text { Set the delay between anti-entropy sessions. } \\
\text { Arguments: } \\
\text { delay - the interval (in ms) between consecutive anti-entropy sessions }\end{array}$ \\
\hline
\end{tabular}




\begin{tabular}{|c|c|}
\hline boolean & $\begin{array}{l}\text { getObjectView() } \\
\text { Return whether the stable view is turned on. }\end{array}$ \\
\hline boolean & $\begin{array}{l}\text { setObjectView (boolean stable) } \\
\text { Set the stable view. If the stable view is on, then only stable writes will } \\
\text { be reflected in the user's view of the database. } \\
\text { Arguments: } \\
\text { stable - true to turn on the stable view, false to turn it off }\end{array}$ \\
\hline void & $\begin{array}{l}\text { retire() } \\
\text { Request that this replica retire. Perform a last anti-entropy session with } \\
\text { another replica. When control returns, the replica is considered retired, } \\
\text { and will accept no further operations or anti-entropy requests. } \\
\text { Exceptions: } \\
\quad \text { IOException - if the replica cannot process a retirement write }\end{array}$ \\
\hline int & $\begin{array}{l}\text { getWhenPolicy() } \\
\text { Get the value of whenPolicy. }\end{array}$ \\
\hline void & $\begin{array}{l}\text { setWhenPolicy (int policy) } \\
\text { Set the value of whenPolicy. }\end{array}$ \\
\hline void & $\begin{array}{l}\text { setMethodLimit (int limit) } \\
\text { Set the number of methods that this replica will execute before perfor- } \\
\text { ming anti-entropy with some replica. }\end{array}$ \\
\hline void & $\begin{array}{l}\text { setWithWhichPolicy(int policy) } \\
\text { Set the value of withWhichPolicy. }\end{array}$ \\
\hline void & $\begin{array}{l}\text { setReplicaName(String replicaName) } \\
\text { Specify this replica's anti-entropy partner. }\end{array}$ \\
\hline
\end{tabular}




\begin{tabular}{|c|l|}
\hline int & $\begin{array}{l}\text { getTruncateLogPolicy() } \\
\text { Get the value of truncateLogPolicy. }\end{array}$ \\
\hline void & $\begin{array}{l}\text { setTruncateLogPolicy(int policy) } \\
\text { Set the value of truncateLogPolicy. }\end{array}$ \\
\hline
\end{tabular}




\section{A.2 Interface Bayou}

\begin{tabular}{|c|c|}
\hline Object & $\begin{array}{l}\text { getVersionVector ( ) } \\
\text { This method returns this object's version vector and CSN. This is needed } \\
\text { during the anti-entropy session, to identify which writes that the sender } \\
\text { holds are unknown to the receiver. }\end{array}$ \\
\hline void & $\begin{array}{l}\text { acceptCommitNotification(String sender, WriteId writeId, } \\
\text { ServerId serverId) } \\
\text { This method is called by a sender who wishes to transmit a commit } \\
\text { notification for a write the receiver already knows about, but presently } \\
\text { holds uncommitted. } \\
\text { Arguments: } \\
\text { sender - the URL-formatted name of the sender } \\
\text { writeId - the id of the write for which the notification is being sent } \\
\text { serverId - the id of the server where the write was generated } \\
\text { Exceptions: } \\
\text { IOException - if the replica cannot process the notification }\end{array}$ \\
\hline void & $\begin{array}{l}\text { acceptWrite (String sender, Write write) } \\
\text { This method is called by a sender who wishes to transmit a write unk- } \\
\text { nown to the receiver. } \\
\text { Arguments: } \\
\text { sender - the URL-formatted name of the sender } \\
\text { write - the write being accepted through anti-entropy } \\
\text { Exceptions: } \\
\text { IOException - if the replica cannot process the write }\end{array}$ \\
\hline
\end{tabular}




\begin{tabular}{|c|c|}
\hline ServerId & $\begin{array}{l}\text { create (String sender) } \\
\text { This method is called by a sender who wishes to create itself. After } \\
\text { processing this write, the receiver will provide a unique server id for the } \\
\text { new replica. } \\
\text { Arguments: } \\
\text { sender - the URL-formatted name of the replica asking to be created } \\
\text { Exceptions: } \\
\text { IOException - if the receiver cannot process a creation write }\end{array}$ \\
\hline void & $\begin{array}{l}\text { acceptCommitted(String sender, VersionVector committed, } \\
\text { long CSN, Vector stableWrites) } \\
\text { This method is called by a sender who wishes to transmit its committed } \\
\text { version vector and CSN to the receiver during a full database transfer. } \\
\text { Arguments: } \\
\text { sender - the URL-formatted name of the replica transferring its state } \\
\text { committed - sender's committed version vector } \\
\text { CSN - sender's commit sequence number } \\
\text { stableWrites - sender's set of stable writes } \\
\text { Exceptions: } \\
\text { IOException - if the receiver cannot process the stable writes }\end{array}$ \\
\hline void & $\begin{array}{l}\text { acceptReplica(String sender, Object replica) } \\
\text { This method is called by a sender who wishes to perform a full-database } \\
\text { transfer with the receiver. Note that the sender sends the database equi- } \\
\text { valent to its stable view. This means that the database transferred alre- } \\
\text { ady reflects all of the stable writes performed at the sender. } \\
\text { Arguments: } \\
\text { sender - the URL-formatted name of the replica transferring its state } \\
\text { replica - sender's state }\end{array}$ \\
\hline
\end{tabular}




\begin{tabular}{|c|c|}
\hline void & $\begin{array}{l}\text { start (Bayou sender) } \\
\text { This method is called by a replica who wishes to start performing anti- } \\
\text { entropy with the receiver. } \\
\text { Arguments: } \\
\text { sender - the stub reference to the sender }\end{array}$ \\
\hline void & $\begin{array}{l}\text { finish (Bayou sender) } \\
\text { This method is called by a replica who wishes to inform the receiver that } \\
\text { it has finished performing anti-entropy with it. } \\
\text { Arguments: } \\
\text { sender - the stub reference to the sender }\end{array}$ \\
\hline void & $\begin{array}{l}\text { transferDatabase(String replica) } \\
\text { Request a full-database transfer. } \\
\text { Arguments: } \\
\text { replica - the URL-formatted name of the requesting replica } \\
\text { Exceptions: } \\
\text { IOException - if the receiver cannot read its own writes from its log } \\
\text { NotBoundException - if replica has not been registered at the na- } \\
\text { ming service }\end{array}$ \\
\hline void & $\begin{array}{l}\text { performAntiEntropy (Bayou sender) } \\
\text { Receive a request from a replica to perform anti-entropy with it. } \\
\text { Arguments: } \\
\text { sender - the stub for the replica requesting anti-entropy }\end{array}$ \\
\hline
\end{tabular}




\section{Referências Bibliográficas}

[1] Ken Arnold, James Gosling, and David Holmes. The Java Programming Language. Addison-Wesley, 2000.

[2] Arash Baratloo, P. Emerald Chung, Yennun Huang, Sampath Rangarajan, and Shalini Yajnik. Filterfresh: Hot Replication of Java RMI Server Objects. In Proceedings of the 4th USENIX Conference on Object-Oriented Technologies and Systems (COOTS), Santa Fe, New Mexico, April 1998.

[3] L. Barreto and I. Jansch-Pôrto. Open and Reliable Group Communication Processing: The FITOS-RPC Approach. In 6th EuroMicro Workshop on Parallel and Distributed Processing, pages 389-394, 1998.

[4] A. Bartoli, B. Kemme, and Ö. Babaoğlu. Online Reconfiguration in Replicated Databases Based on Group Communications. Technical Report UBLCS-2000-17, Departement of Computer Science, University of Bologna, Mura Anteo Zamboni 7, 40127 Bologna (Italy), December 2000.

[5] Bayou Homepage. http://www.parc.xerox.com/csl/projects/bayou/.

[6] P. Bernstein, V. Hadzilacos, and N. Goodman. Concurrency Control and Recovery in Database Systems. Addison-Wesley, 1987.

[7] Phil Bernstein and Nathan Goodman. The Failure and Recovery Problem for Replicated Distributed Databases. ACM Transactions on Database Systems, 9(4), December 1984.

[8] Brian N. Bershad, Thomas E. Anderson, Edward D. Lazowska, and Henry M. Levy. Lightweight Remote Procedure Call. IEEE Concurrency, pages 5-7, JulySeptember 1998.

[9] A. D. Birrell, R. Levin, R. M. Needham, and M. D. Schroeder. Grapevine: An Exercise in Distributed Computing. Communications of the ACM, 25(4):260-274, April 1982. 
[10] A. D. Birrell and B. J. Nelson. Implementing Remote Procedure Call. ACM Transactions on Computer Systems, 2(1):39-59, 1984.

[11] F. Buschmann, R. Meunier, H. Rohnert, P. Sommerland, and M. Stal. Patternoriented Software Architecture - A System of Patterns. Wiley, 1996.

[12] Mary Campione, Kathy Walrath, and Alison Huml. The Java Tutorial: A Short Course on the Basics. Addison-Wesley, 2000.

[13] J. B. Carter, J. K. Bennett, and W. Zwaenepoel. Implementation and Performance of Munin. In Proceedings of the 13th ACM Symp. on Operating Systems Principles (SOSP-13), pages 152-164, 1991.

[14] D. R. Cheriton. Exploiting Recursion to Simplify RPC Communication Architectures. In Proceedings of the ACM SIGCOMM, 1988.

[15] R. Chow and T. Johnson. Distributed Operating Systems and Algorithms. AddisonWesley, 1997.

[16] Oracle Corporation. Oracle7 Server Distributed Systems: Replicated Data, Release 7.1. Technical Report Part no. A21903-2, 1995.

[17] Dilma Menezes da Silva, Marco Dimas Gubitoso, and Markus Endler. Sistemas de Informação Distribuídos para Agentes Móveis. In Proceedings of the XXV Brazilian Software and Hardware Seminars (SEMISH'98), pages 125-140, Belo Horizonte, Brazil, August 1998.

[18] S. Davidson, H. Garcia-Molina, and D. Skeen. Consistency in a Partitioned Network: A Survey. ACM Computing Surveys, 17(3):341-370, September 1985.

[19] Aurélio Buarque de Holanda Ferreira. Novo Dicionário Aurélio da Língua Portuguesa. Editora Nova Fronteira, 1986.

[20] A. Demers, D. Greene, C. Hauser, W. Irish, J. Larson, S. Shenker, H. Sturgis, D. Swinehart, and D. Terry. Epidemic Algorithms for Replicated Database Maintenance. In Proceedings of the Sixth Annual ACM Symposium on Principles of Distributed Computing, pages 1-12, Vancouver, Canada, August 1987.

[21] A. J. Demers, K. Petersen, M. J. Spreitzer, D. B. Terry, M. M. Theimer, and B. B. Welch. The Bayou Architecture: Support for Data Sharing among Mobile Users. In Proceedings of the Workshop on Mobile Computing Systems and Applications, pages 2-7, Santa Cruz, California, December 1994.

[22] W. K. Edwards, E. D. Mynatt, K. Petersen, M. J. Spreitzer, D. B. Terry, and M. M. Theimer. Designing and Implementing Asynchronous Collaborative Applications with Bayou. In Proceedings of the Tenth ACM Symposium on User Interface 
Software and Technology (UIST), pages 119-128, Banff, Alberta, Canada, October 1997.

[23] Pascal Felber and André Schiper. Optimistic Active Replication. In 21st International Conference on Distributed Computing Systems, pages 333-341, April 2001.

[24] G. H. Forman and J. Zahorjan. The Challenges of Mobile Computing. IEEE Computer, 27(6), April 1994.

[25] Erich Gamma, John Vlissides, Ralph Johnson, and Richard Helm. Design Patterns: Elements of Reusable Object Oriented Software. Addison-Wesley, 1994.

[26] R. A. Golding. A Weak-consistency Architecture for Distributed Information Systems. Computing Systems, 5(4):379-405, Fall 1992.

[27] Jim Gray, Pat Helland, Patrick O'Neil, and Dennis Shasha. The Dangers of Replication and a Solution. In Proceedings of the 1996 ACM SIGMOD International Conference on Management of Data, pages 173-182, Montreal, Quebec, Canada, June 1996.

[28] Object Management Group. Common Object Request Broker: Architecture and Specification. Framingham, Massachusetts, 1997.

[29] Richard Guy, Peter Reicher, David Ratner, Michial Gunter, Wilkie Ma, and Gerald Popek. Rumor: Mobile Data Access Through Optimistic Peer-to-peer Replication. In Proceedings of the ER'98 Workshop on Mobile Data Access, 1998.

[30] Richard G. Guy, John S. Heidemann, Wai Mak, Thomas W. Page Jr., Gerald J. Popek, and Dieter Rothmeier. Implementation of the Ficus Replicated File System. In Proceedings of the Summer 1990 USENIX Conference, pages 63-71, Anaheim, CA, June 1990.

[31] J. Holliday, R. Steinke, D. Agrawal, , and A. El Abbadi. Epidemic Quorums for Managing Replicated Data. Technical report, Department of Computer Science, University of California at Santa Barbara, 1999.

[32] Yixiu Huang, A. Prasad Sistla, and Ouri Wolfson. Data Replication for Mobile Computers. In Proceedings of the 1994 ACM SIGMOD International Conference on Management of Data, pages 13-24, Minneapolis, Minnesota, May 1994. ACM Press.

[33] Cristian Ionitoiu. Replicated Objects with Lazy Consistency. In ECOOP'96 Workshop on Mobility and Replication, Linz, Austria, 1996.

[34] JavaSoft. Java Core Reflection - API and Specification, January 1997. 
[35] Jin Jing, Ahmed K. Elmagarmid, Abdelsalam Helal, and Rafael Alonso. BitSequences: An Adaptive Cache Invalidation Method in Mobile Client/Server Environments. Mobile Networks and Applications, 2(2):115-127, 1997.

[36] Clovis Seragiotto Júnior. Detecção Dinâmica de Condições de Disputa para Programas Multithreaded em Java. Master's thesis, Instituto de Matemática e Estatística - USP, 2000.

[37] A. D. Joseph, A. F. deLespinasse, J. A. Tauber, D. K. Gifford, and M. F. Kaashoek. Rover: A toolkit for Mobile Information Access. In Proceedings of the 15th ACM Symposium on Operating Systems Principles (SOSP-95), Copper Mountain Resort, Colorado, December 1995.

[38] A. D. Joseph, J. A. Tauber, and M. F. Kaashoek. Mobile Computing with the Rover Toolkit. IEEE Transactions on Computers: Special Issue on Mobile Computing, March 1997.

[39] Bill Joy, Guy Steele, James Gosling, and Gilad Bracha. The Java Language Specification. Addison-Wesley, 2000.

[40] Leonard Kawell Jr., Steven Beckhardt, Timothy Halvorsen, and Irene Grief. Replicated Document Management in a Group Communication System. In Proceedings of the ACM Conference on Computer-Supported Cooperative Work, Portland, Oregon, September 1988.

[41] P. Keleher. Decentralized Replicated-Object Protocols. In The 18th Annual ACM SIGACT-SIGOPS Symposium on Principles of Distributed Computing, April 1999.

[42] P. Keleher and U. Cetintemel. Consistency Management in Deno. The Journal on Special Topics in Mobile Networking and Applications (MONET), 1999.

[43] P. Keleher, A. L. Cox, and W. Zwaenepoel. Lazy Release Consistency for Software Distributed Shared Memory. In Proceedings of the 19th Annual Int'l Symp. on Computer Architecture (ISCA'92), pages 13-21, 1992.

[44] P. Keleher, S. Dwarkadas, A. L. Cox, and W. Zwaenepoel. TreadMarks: Distributed Shared Memory on Standard Workstations and Operating Systems. In Proceedings of the Winter 1994 USENIX Conference, pages 115-131, January 1994.

[45] J. J. Kistler and M. Satyanarayanan. Disconnected Operation in the Coda File System. ACM Transactions on Computer Systems, 10(1):213-225, February 1992.

[46] V. Krishnaswamy, D. Walther, S. Bhola, E. Bommaiah, G. Riley, B. Topol, and M. Ahamad. Efficient Implementations of Java RMI. In Proceedings of the 4 th USENIX Conference on Object-Oriented Technologies and Systems (COOTS'98), April 1998. 
[47] L. Lamport. Time, Clocks, and the Ordering of Events in a Distributed System. Communications of the ACM, 21(7):558-565, July 1978.

[48] Richard Lenz. The "Virtual-Primary-Copy Approach" Compared To Other Approaches With Weak Consistent Data Replication. University of Erlangen-Nuremberg, 1996.

[49] Tim Lindholm and Frank Yellin. The Java Virtual Machine Specification. AddisonWesley, 1999.

[50] B. Liskov and L. Shrira. Promises: Linguistic Support for Efficient Asynchronous Procedure Calls in Distributed Systems. In Proceedings of the ACM SIGPLAN '88 Conference on Programming Language Design and Implementation (PLDI), pages 260-267, June 1988.

[51] J. Maassen, T. Kielmann, and H. Bal. Parallel Application Experience with Replicated Method Invocation. Concurrency and Computation: Practice and Experience, 2001.

[52] Jason Maassen, Thilo Kielmann, and Henri E. Bal. Efficient Replicated Method Invocation in Java. In ACM Java Grande, pages 88-96, 2000.

[53] Jason Maassen, Rob van Nieuwpoort, Ronald Veldema, Henri E. Bal, Thilo Kielmann, Ceriel Jacobs, and Rutger Hofman. Efficient Java RMI for Parallel Programming, March 2000. Submitted to publication.

[54] Jason Maassen, Rob van Nieuwpoort, Ronald Veldema, Henri E. Bal, and Aske Plaat. An Efficient Implementation of Java's Remote Method Invocation. In Principles Practice of Parallel Programming (PPoPP), pages 173-182, July 1999.

[55] Microsoft. The Component Object Model Specification. Redmond, Washington, October 1995.

[56] Sun Microsystems. Java Object Serialization Specification, 1998.

[57] Sun Microsystems. Java Remote Method Invocation Specification (RMI), October 1998.

[58] Robin Milner. A Theory of Type Polymorphism in Programming. Journal of Computer and System Sciences, 17(3):348-375, December 1978.

[59] L. B. Mummert, M. R. Ebling, and M. Satyanarayanan. Exploiting Weak Connectivity for Mobile File Access. In Proceedings of the 15th ACM Symposium on Operating System Principles.

[60] B. J. Nelson. Remote Procedure Call. PhD thesis, Department of Computer Science, Carnegie-Mellon University, Pittsburgh, 1981. 
[61] Christian Nester, Michael Philippsen, and Bernhard Haumacher. A More Efficient RMI for Java. In Java Grande, pages 152-159, San Francisco, CA, June 1999.

[62] OMG. OMG IDL Syntax and Semantics, The Common Object Request Broker: Architecture and Specification, February 2001. Version 2.4.2.

[63] E. Pacitti, P. Minet, and E. Simon. Fast Algorithms for Maintaining Replica Consistency in Lazy Master Replicated Databases. In Proceedings of the 25th International Conference on Very Large Databases, Edinburgh, Scotland, UK, September 1999.

[64] Karin Petersen, Mike J. Spreitzer, Douglas B. Terry, Marvin M. Theimer, and Alan J. Demers. Flexible Update Propagation for Weakly Consistent replication. In Proceedings of the 16th Symposium on Operating Systems Principles (SOSP97), pages 288-301, New York, October 1997.

[65] Michael Philippsen, Bernhard Haumacher, and Christian Nester. More Efficient Serialization and RMI for Java. Concurrency - Practice and Experience, 12(7):495$518,2000$.

[66] Michael Philippsen and Matthias Zenger. JavaParty - Transparent Remote Objects in Java. Concurrency: Practice and Experience, 9(11):1225-1242, 1997.

[67] Evaggelia Pitoura and George Samaras. Data Management for Mobile Computing. Kluwer Academic Publishers, 1998.

[68] Steven A. Rago. UNIX System V Network Programming. Addison-Wesley, 1993.

[69] R. Riggs, J. Waldo, A. Wollrath, and K. Bharat. Pickling State in the Java System. In Proceedings of the USENIX 1996 Conference on Object-Oriented Technologies (COOTS), pages 241-250, Toronto, Ontario, Canada, 1996.

[70] Yasushi Saito. Optimistic Replication Algorithms. Technical report, August 2000.

[71] M. Satyanarayanan. Coda: A Highly Available File System for a Distributed Workstation Environment. In Proceedings of the Second IEEE Workshop on Workstation Operating Systems, Pacific Grove, CA, September 1989.

[72] M. Stonebraker. Concurrency Control and Consistency of Multiple Copies of Data in Distributed INGRES. IEEE Transactions on Software Engineering, 5(3):188194, May 1979.

[73] Sun Microsystems. XDR: External Data Representation Standard, 1987.

[74] Douglas Terry, Marvin Theimer, Karin Petersen, Alan Demers, Mike Spreitzer, and Carl H. Hauser. Managing Update Conflict in Bayou, a Weakly Connected Replicated Storage System. In Proceedings of the 15th ACM Symposium on 
Operating Systems Principles (SOSP-95), Copper Mountain Resort, Colorado, December 1995.

[75] Douglas B. Terry, Alan J. Demers, Karin Petersen, Mike Spreitzer, Marvin Theimer, and Brent W. Welch. Session Guarantees for Weakly Consistent Replicated Data. In Proceedings of the Third International Conference on Parallel and Distributed Information Systems (PDIS 94), pages 140-149, Austin, Texas, September 1994. IEEE Computer Society.

[76] Jim Waldo. Remote Procedure calls and Java Remote Method Invocation. IEEE Concurrency, pages 5-7, July-September 1998.

[77] M. Wiesmann, F. Pedone, and A. Schiper. Understanding Replication in Databases and Distributed Systems. In Proceedings of 20th International Conference on Distributed Computing Systems (ICDCS'2000), pages 264-274, Taipei, Taiwan, R.O.C., 2000.

[78] Ann Wollrath, Roger Riggs, and Jim Waldo. A Distributed Object Model for the Java System. Computing Systems, 9(4):265-290, 1996.

[79] Frank Yellin. The Java Native Code Interface, 1996.

[80] H. Yu and A. Vahdat. Design and Evaluation of a Continuous Consistency Model for Replicated Services. In Proceedings of Operating Systems Design and Implementation, October 2000.

[81] Weimin Yu and Alan Cox. Java/DSM: A Platform for Heterogeneous Computing. Concurrency: Practice and Experience, 9(11):1213-1224, November 1997.

[82] Y. Zhou, L. Iftode, and K. Li. Performance Evaluation of Two Home-Based Lazy Release Consistency Protocols for Shared Memory Virtual Memory Systems. In Proceedings of the 2nd Symp. on Operating Systems Design and Implementation (OSDI'96), pages 75-88, 1996. 